\title{
Bechtel Nevada
}

\section{Mineralogic Zonation Within the Tuff Confining Unit, Yucca Flat, Nevada Test Site}

\author{
by \\ Lance Prothro \\ Geotechnical Sciences Group \\ Bechtel Nevada \\ Las Vegas, Nevada
}




\title{
DISCLAIMER STATEMENT
}

Reference herein to any specific commercial product, process, or service by trade name, trademark, manufacturer, or otherwise, does not necessarily constitute or imply its endorsement, recommendation, or favoring by the U.S. Government or any agency thereof. The views and opinions of authors expressed herein do not necessarily state or reflect those of the U.S.

Government or any agency thereof.

\section{AVAILABILITY STATEMENT}

Available to the public, in paper, from:

\author{
U.S. Department of Commerce \\ National Technical Information Service \\ 5285 Port Royal Road \\ Springfield, VA, 22161-0002 \\ Telephone: 800.553.6847 \\ Fax: 703.605.6900 \\ E-mail: orders@ntis.gov \\ Online ordering: http://www.ntis.gov/ordering.htm
}

Available electronically at http://www.osti.gov/bridge.

Available for a processing fee to U.S. Department of Energy and its contractors, in paper, from:

U.S. Department of Energy

Office of Scientific and Technical Information

P.O. Box 62

Oak Ridge, TN 37831-0062

Telephone: 865.576.8401

Fax: 865.576.5728

E-mail: reports@adonis.osti.gov 


\title{
Bechtel Nevada
}

\section{Mineralogic Zonation Within the Tuff Confining Unit, Yucca Flat, Nevada Test Site}

\author{
by \\ Lance Prothro \\ Geotechnical Sciences Group \\ Bechtel Nevada \\ Las Vegas, Nevada
}

September 2005

This manuscript was produced by Bechtel Nevada under Contract No. DE-AC08-96NV11718 with the U.S. Department of Energy 
This Page Intentionally Left Blank. 


\title{
Mineralogic Zonation Within the Tuff Confining Unit, Yucca Flat, Nevada Test Site
}

\begin{abstract}
Recently acquired mineralogic data from drill hole samples in Yucca Flat show that the tuff confining unit (TCU) can be subdivided into three mineralogic zones based on the relative abundances of primary and secondary mineral assemblages. These zones are (1) an upper zone characterized by the abundance of the zeolite mineral clinoptilolite with lesser amounts of felsic and clay minerals; (2) a middle zone with felsic minerals dominant over clinoptilolite and clay minerals; and (3) a basal argillic zone where clay minerals are dominant over felsic minerals and clinoptilolite. Interpretation of the mineralogic data, along with lithologic, stratigraphic, and geophysical data from approximately 500 drill holes, reveals a three-layer mineralogic model for the TCU that shows all three zones are extensive beneath Yucca Flat.

The mineralogic model will be used to subdivide the TCU in the Yucca Flat hydrostratigraphic framework model, resulting in a more accurate and versatile framework model. In addition, the identification of the type, quantity, and distribution of minerals within each TCU layer will permit modelers to better predict the spatial distribution and extent of contaminant transport from underground tests in Yucca Flat, at both the level of the hydrologic source term and the corrective action unit.
\end{abstract}


This page intentionally left blank. 


\section{Table of Contents}

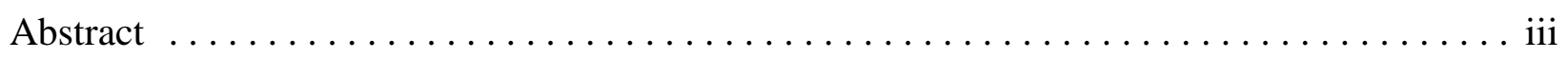

List of Figures $\ldots \ldots \ldots \ldots \ldots \ldots \ldots \ldots \ldots \ldots \ldots \ldots \ldots \ldots \ldots \ldots \ldots \ldots$

List of Tables $\ldots \ldots \ldots \ldots \ldots \ldots \ldots \ldots \ldots \ldots \ldots \ldots \ldots \ldots \ldots \ldots \ldots \ldots \ldots \ldots \ldots \ldots$

List of Acronyms and Abbreviations $\ldots \ldots \ldots \ldots \ldots \ldots \ldots \ldots \ldots \ldots \ldots \ldots \ldots$ vii

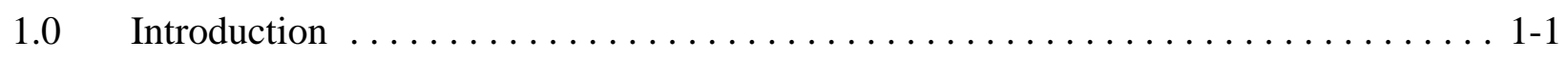

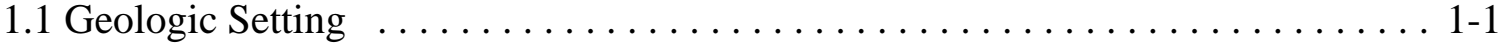

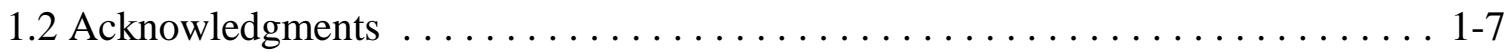

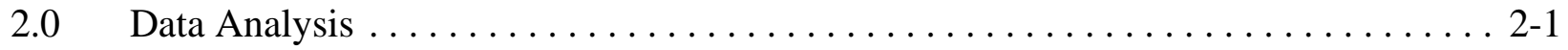

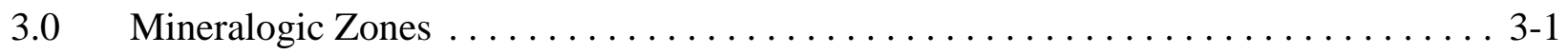

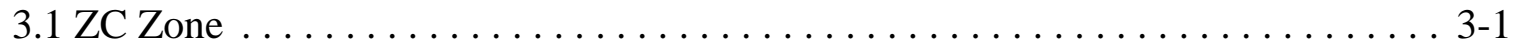

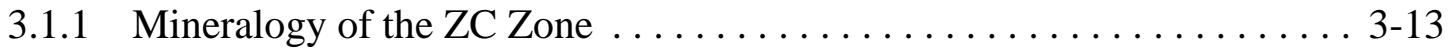

3.1.2 Stratigraphy and Lithology of the ZC Zone . . . . . . . . . . . . 3-14

3.1.3 Extent and Thickness of the ZC Zone .................. 3-14

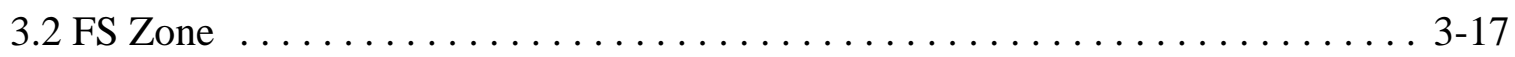

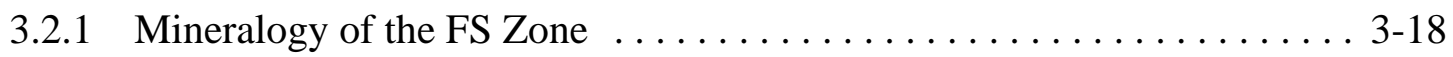

3.2.2 Stratigraphy and Lithology of the FS Zone . . . . . . . . . . . 3-19

3.2.3 Extent and Thickness of the FS Zone $\ldots \ldots \ldots \ldots \ldots \ldots \ldots \ldots . \ldots \ldots$

3.3 AR Zone . . . . . . . . . . . . . . . . . . . . . . . . . . . . . .

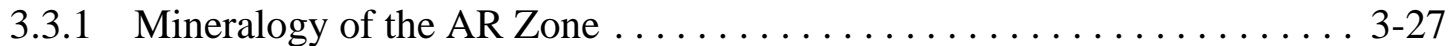

3.3.2 Stratigraphy and Lithology of the AR Zone $\ldots \ldots \ldots \ldots \ldots \ldots \ldots$. . . . . . . .

3.3.3 Extent and Thickness of the AR Zone . . . . . . . . . . . . . 3-31

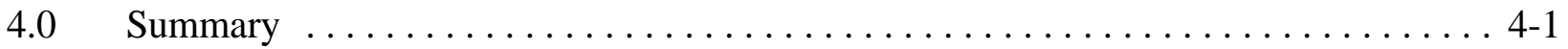

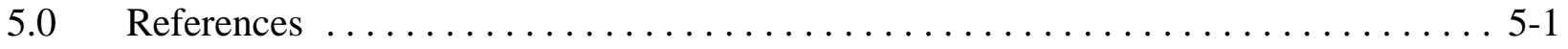

Appendix A- X-ray Diffraction Results

Appendix B. Drill Hole Database 


\section{List of Figures}

Number

Title

Page

1-1 Shaded Relief Map of Yucca Flat and Vicinity $\ldots \ldots \ldots \ldots \ldots \ldots \ldots \ldots \ldots$

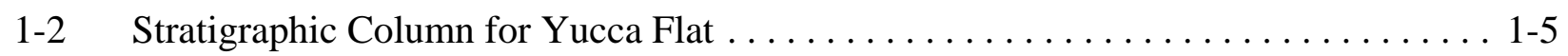

1-3 Color Elevation Relief Map of the Pre-Tertiary Surface Beneath

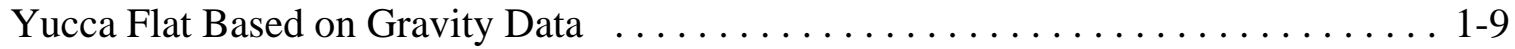

3-1 Mineral Abundances for the TCU in Yucca Flat $\ldots \ldots \ldots \ldots \ldots \ldots \ldots \ldots \ldots$

3-2 Abundances of the Major TCU Minerals Versus Depth . . . . . . . . . . . . . 3-5

3-3 Relative Abundances of the Major TCU Minerals for Each of the

Mineralogic Zones . . . . . . . . . . . . . . . . . . . . . . .

3-4 Cross-sectional Diagram Through Drill Holes U3mi, U3mh, U3cn5,

UE7f, and UE7ax Showing Mineralogic Zones Within the TCU . . . . . . . . . 3-11

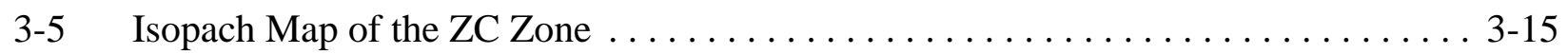

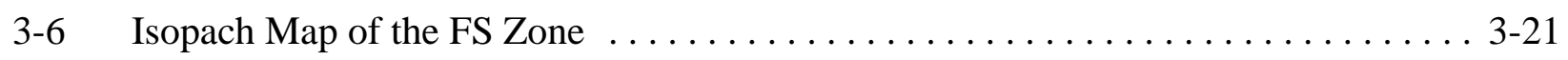

3-7 Photograph of Argillic Rocks in Drill Hole UE7f . . . . . . . . . . . . . . . . . 3-25

3-8 Diagram of Drill Hole UE7f Showing Relationships Between the

Electric Log, Caliper Log, and Clay Content . . . . . . . . . . . . . . . . . 3-29

3-9 Isopach Map of the AR Zone $\ldots \ldots \ldots \ldots \ldots \ldots \ldots \ldots \ldots \ldots \ldots \ldots \ldots \ldots \ldots$

\section{List of Tables}

3-1 List of Minerals and Their Average Abundances for Each

TCU Mineralogic Zone . . . . . . . . . . . . . . . . . . . . 3-9 


\section{List of Acronyms and Abbreviations}

$\begin{array}{ll}\text { AR } & \text { clay or argillic } \\ \text { BN } & \text { Bechtel Nevada } \\ \text { CAU } & \text { Corrective Action Unit } \\ \text { CT } & \text { cristobalite/tridymite } \\ \text { FS } & \text { felsic or felsic minerals } \\ \mathrm{ft} & \text { feet } \\ \text { FY } & \text { Fiscal Year } \\ \text { K-feldspar } & \text { potassium feldspar } \\ \text { LANL } & \text { Los Alamos National Laboratory } \\ \text { LLNL } & \text { Lawrence Livermore National Laboratory } \\ \text { m } & \text { meters } \\ \text { Ma } & \text { million years ago } \\ \mathrm{n} & \text { population number } \\ \text { SNJV } & \text { Stoller-Navarro Joint Venture } \\ \text { TCU } & \text { tuff confining unit } \\ \text { USGS } & \text { U.S. Geological Survey } \\ \text { XRD } & \text { X-ray diffraction } \\ \text { ZC } & \text { clinoptilolite }\end{array}$


This page intentionally left blank. 


\subsection{Introduction}

This report describes a three-dimensional model of mineralogic zonation within the tuff confining unit (TCU) beneath Yucca Flat (Figure 1-1). The model is the result of a three-year cooperative effort by scientists from Bechtel Nevada (BN), Los Alamos National Laboratory (LANL), Lawrence Livermore National Laboratory (LLNL), and Stoller-Navarro Joint Venture (SNJV) to better define the nature and extent of the TCU in Yucca Flat. The TCU is important to contaminant transport models in Yucca Flat because (1) most of the underground nuclear tests in Yucca Flat were conducted either within this unit, or within the overlying alluvial and tuff aquifers, and (2) geologic models show that the TCU is laterally extensive beneath Yucca Flat which may provide a barrier between the hydrologic source term and the underlying lower carbonate aquifer.

The data and interpretations developed as a part of this study will be used to constrain contaminant transport models of the Yucca Flat Corrective Action Unit (CAU). The TCU mineralogic model will provide additional map layers (i.e., hydrostratigraphic units) for the hydrostratigraphic framework model being developed for Yucca Flat. In addition, TCU alteration minerals play a major role in retarding radionuclides via sorption and ion exchange processes (Tompson et al., 1999). Identification of the type, quantity, and distribution of these minerals will permit modelers to better predict the spatial distribution and extent of contaminant transport from underground tests in Yucca Flat, at both the hydrologic source term and CAU-level scales.

\subsection{Geologic Setting}

Yucca Flat is a north-south-elongated, Neogene-age basin formed in response to basin-and-range extension. Major basin development appears to have begun shortly after the eruption of the Ammonia Tanks Tuff approximately 11.5 million years ago (Ma). At its deepest point the basin probably contains more than 910 meters (m) (3,000 feet [ft]) of alluvial debris shed from the surrounding highlands during basin development. This thick alluvial section overlies a thick section of Miocene volcanic rocks of generally rhyolitic composition erupted from caldera sources located west and northwest of the basin. The volcanic rocks lie unconformably on Paleozoic sedimentary rocks (Figure 1-2).

Large down-to-the-east normal faults such as the Carpetbag, Topgallant, and Yucca faults are located near the center of the basin. These faults drop down the east side of Yucca Flat basin 
This page intentionally left blank. 


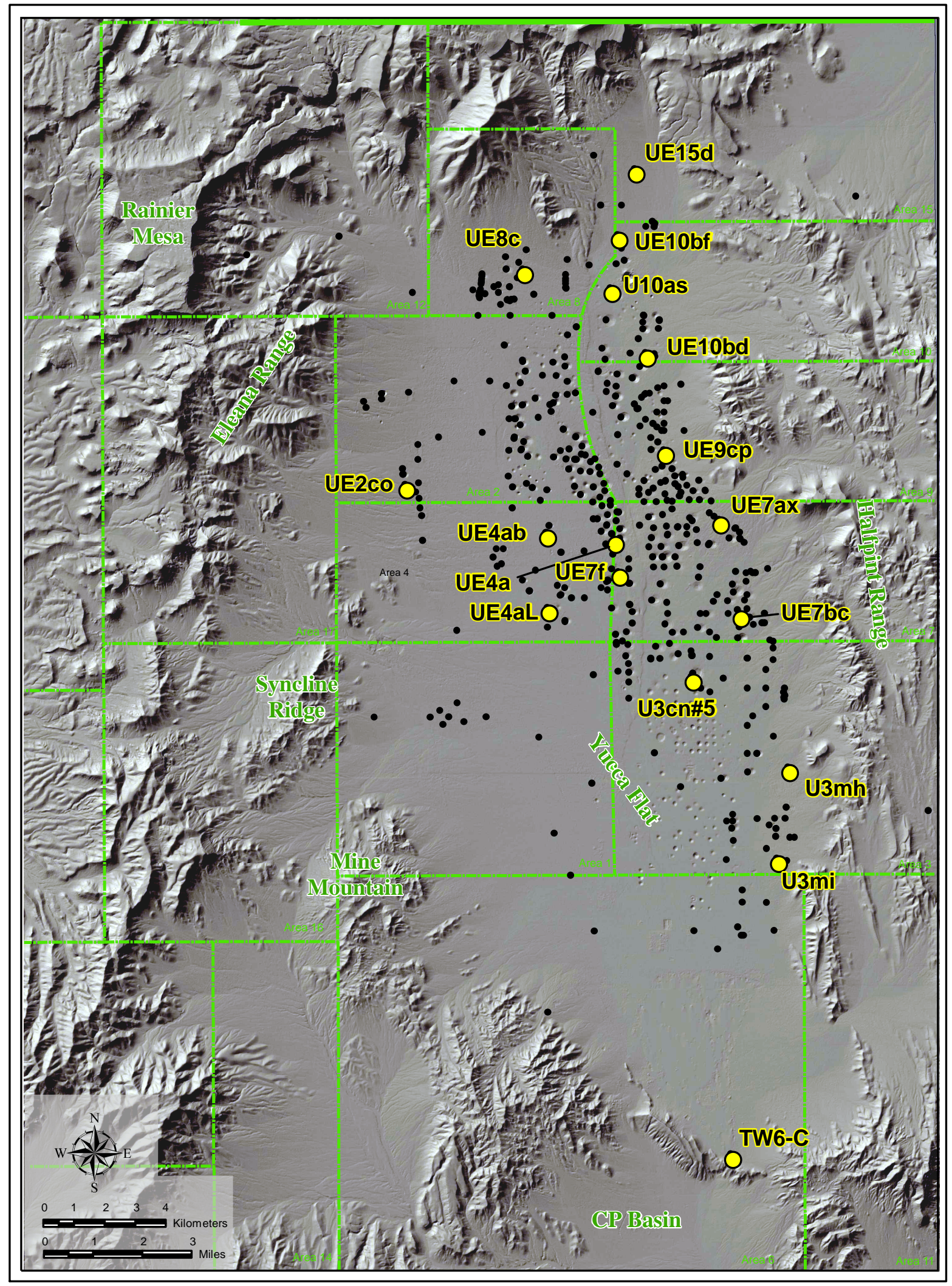

Figure 1-1

Shaded Relief Map of Yucca Flat and Vicinity

Yellow dots are TCU study holes with detailed mineralogic analyses;

black dots are other holes utilized for this study. 
This page intentionally left blank. 


\section{Stratigraphic Column}

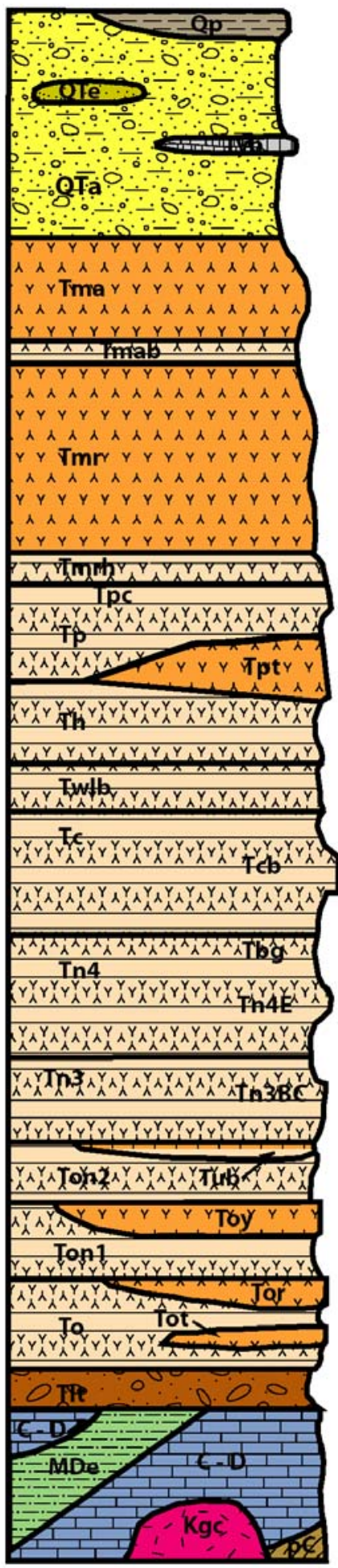

\section{Stratigraphic Nomenclature}

Playa deposits

Eolian sand lenses

Basalt of Yucca Flat

Alluvium

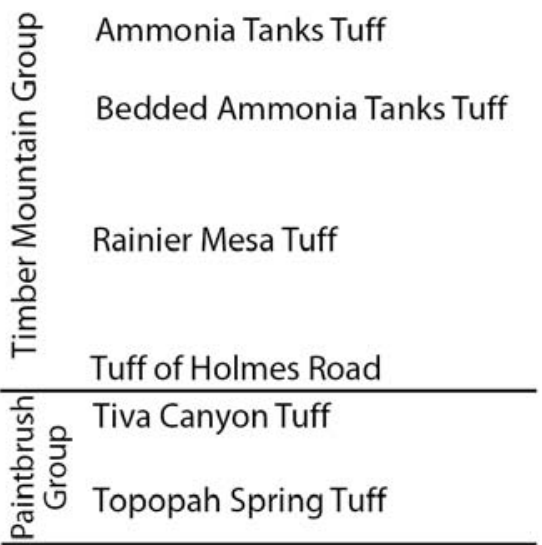

Calico Hills Formation

Tuff of Wahmonie Flat

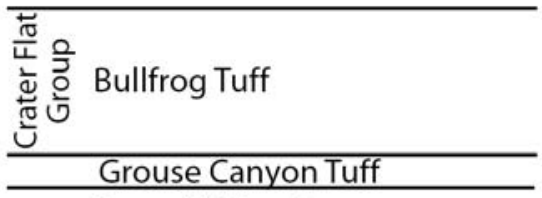

Tunnel 4 Member

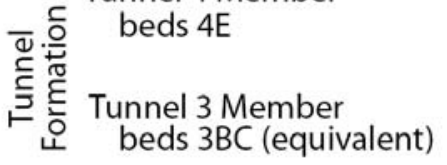

Tub Spring Tuff

\begin{tabular}{|c|}
\hline 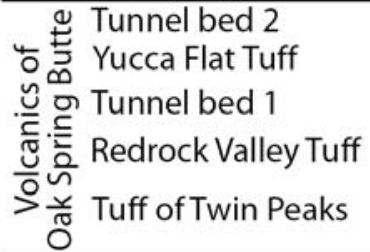 \\
\hline Paleocolluvium \\
\hline
\end{tabular}

Pre-Tertiary Rocks

\section{Explanation}

clay and silt

eolian deposits

lava (basalt)

alluvium

welded

ash-flow tuff

non-welded and

bedded tuff

paleocolluvium

silty shale/

quartzite

limestone/

dolomite

intrusive granite

$p \in$ sediments

Figure 1-2

Stratigraphic Column for Yucca Flat 
This page intentionally left blank. 
forming the deep west-tilted Yucca Flat basin proper (Figure 1-3). West of the CarpetbagTopgallant fault system, a high, north-trending buried structural ridge separates Yucca Flat basin proper from a smaller and shallower western sub-basin. Along the buried ridge, volcanic rocks are generally absent and pre-Tertiary rocks are within $22.0 \mathrm{~m}$ (72 ft) of the land surface. These structural features significantly influence the distribution of the TCU beneath Yucca Flat.

The volcanic rocks beneath the basin range in age from approximately 15 to $11.5 \mathrm{Ma}$ and consist mostly of nonwelded to densely welded ash-flow tuffs, ash-fall deposits, and reworked tuffs. These types of volcanic deposits typically contain large proportions of glass when originally deposited. However, with time and particularly in the presence of groundwater, the glass within the poorly welded rocks tends to alter to zeolite. This alteration significantly reduces the effective porosity of the rocks. This is the scenario that created the tuff confining unit beneath Yucca Flat. As the Yucca Flat basin developed, the unaltered glassy volcanic rocks were dropped down below the water table and altered to zeolite, significantly reducing the ability of these rocks to transmit water, and forming the TCU. As mentioned previously, the position of the TCU between the overlying alluvial and volcanic aquifers in which most of the underground nuclear tests were conducted, and the Paleozoic rocks which form the regional aquifer, make the TCU an important hydrogeologic unit in the Yucca Flat vicinity.

\subsection{Acknowledgments}

The author would like to thank the numerous people who contributed through the years to the successful completion of this investigation. The enthusiastic support and guidance of Gayle Pawloski (LLNL) throughout this investigation is greatly appreciated. Rick Warren's (LANL) early support, guidance, and insights were critical in establishing the initial scope and direction of the study. Brian Allen's (BN) assistance in the first year of this study is also appreciated. Sig Drellack's (BN) insights into the geology of Yucca Flat were very helpful. The author is extremely grateful to Giday WoldeGabriel and Steve Chipera of the Hydrology, Geochemistry, and Geology Group of the Earth and Environmental Sciences Division at LANL for conducting the laboratory analyses and providing the X-ray diffraction (XRD) results along with stimulating discussions and insights regarding alteration of volcanic rocks. Thanks also to Jerry Magner and the staff of the U.S. Geological Survey (USGS) Core Library and Geologic Data Center in Mercury, Nevada for their assistance during collection of the TCU samples. Insightful and stimulating discussions with Tim Rose (LLNL) and Bob Dickerson (SNJV) regarding results of stable isotope and SEM results of TCU samples were very helpful. Aaron Leavitt's (BN) help in producing maps and figures greatly improved the report. The report was improved significantly 
This page intentionally left blank. 


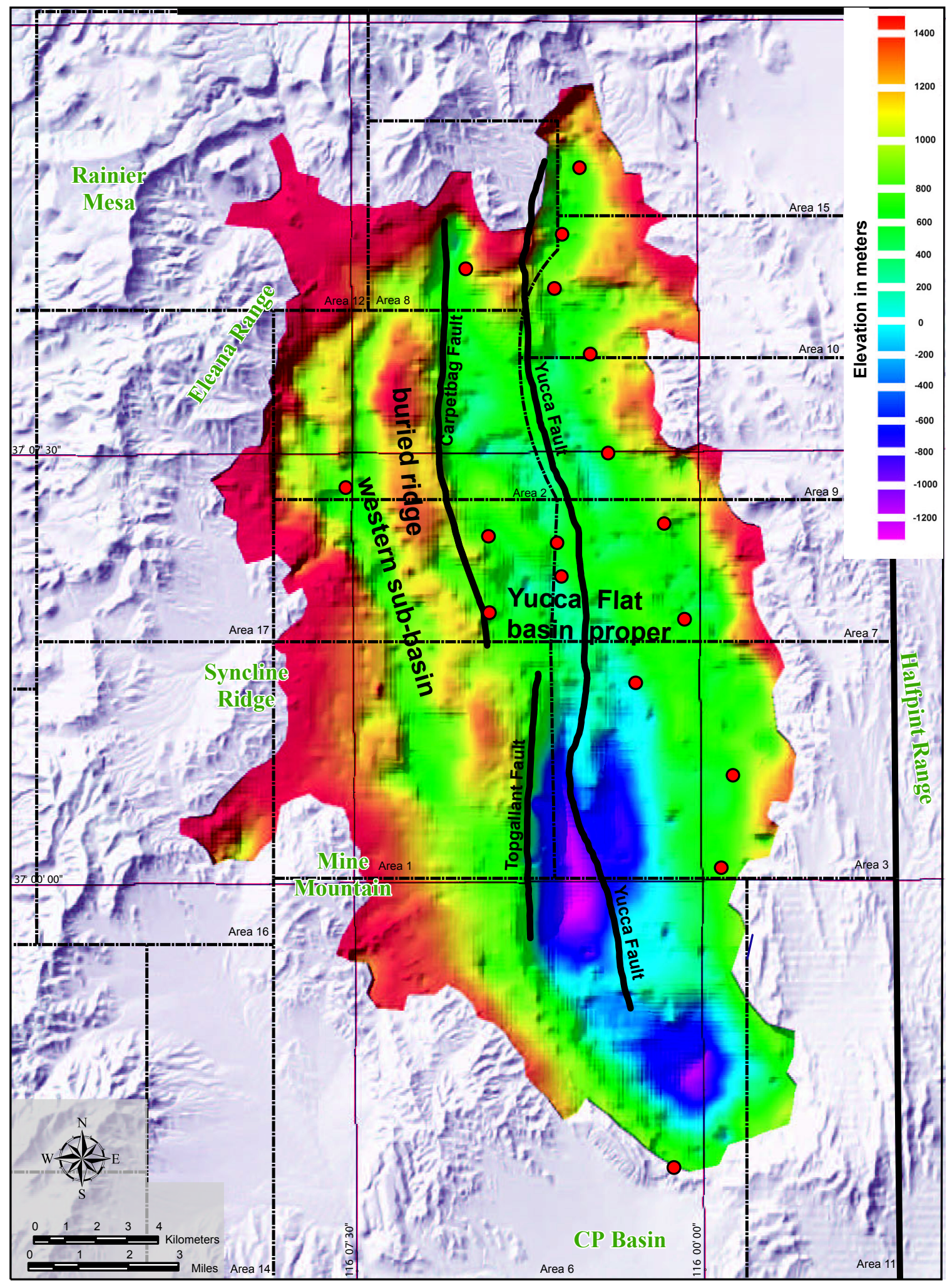

Figure 1-3

Color Elevation Relief Map of the Pre-Tertiary Surface Beneath Yucca Flat Based on Gravity Data

Red dots are TCU study holes with detailed mineralogic analyses.

(Modified from Phelps et al., 1999) 
This page intentionally left blank. 
by the timely reviews of Margaret Townsend (BN), Sigmund Drellack, Stuart Rawlinson (BN), Gayle Pawloski, Giday WoldeGabriel, and Justin Evans (BN).

This work was supported by the U.S. Department of Energy, National Nuclear Security Administration Nevada Site Office, under Contract No. DE-AC08-96NV11718. 
This page intentionally left blank. 


\subsection{Data Analysis}

Work on the TCU study began in October 1999, with the compilation and evaluation of existing data from Yucca Flat drill holes, including lithologic and geophysical logs, and mineralogic and chemical analyses (Prothro et al., 1999, written communication). A preliminary analysis of the existing data indicated that the TCU was mineralogically zoned with regard to major alteration minerals including: (1) an upper zone of predominantly clinoptilolite alteration; (2) a middle zone of more complex alteration mineralogy; and (3) a basal zone of pervasive argillic alteration. This zonation is similar to that described by Hoover (1968) for zeolite zonation at the Nevada Test Site. To further investigate and define the mineralogic zonation within the TCU, 17 holes were selected for additional sampling in Fiscal Year (FY) 2000. The holes are TW6c, UE2co, U3cn5, U3mh, U3mi, UE4a, UE4ab, UE4aL, UE7ax, UE7bc, UE7f, UE8c, UE9cp, U10as, UE10bd, UE10bf, and UE15d. These study holes were selected on the basis of various criteria such as location, thickness of TCU encountered, amount of existing analytical data, and type and quality of available lithologic samples.

Lithologic samples from 134 depths were collected during FY 2000 from 16 of the 17 study holes (Prothro, 2000, written communication). Samples from 18 additional depths in U3mi, UE7ax, UE7bc, and UE7f, that had been acquired during previous studies and stored at LANL, were also utilized. Laboratory analyses performed in FY 2000 on the 152 TCU study samples included XRD, X-ray fluorescence, and wet chemical analysis for divalent iron.

Results from the XRD analyses were compiled in FY 2004, with an additional 32 existing LANL XRD results from U3mh and U3mi, for a total of 184 mineralogical analyses (Appendix A). Published XRD results from TW6c, UE4a, and UE15d were reviewed but not integrated into the TCU data set due to differences in how the older results are reported.

Analysis of the XRD results confirmed and better defined the 3-layer model for alteration minerals within the TCU beneath Yucca Flat (see Section 3.0). Stratigraphic, lithologic, and geophysical data were compared with the mineralogic data from the 17 holes to investigate controlling factors on the mineralogic zonation. These data were also correlated and compared from hole to hole to further investigate controlling factors as well as lateral variation. As a result, it was determined that existing lithologic descriptions and geophysical logs could be utilized to provide a first approximation of the tops of mineralogic layers in other Yucca Flat drill holes that lacked sufficient mineralogic data. Stratigraphic data (Drellack and Thompson, 1990; Pawloski, 1997, written communication; Drellack and Gonzales, 1998, written 
communication), lithologic descriptions, and geophysical logs from approximately 500 drill holes in Yucca Flat were utilized. The tops of each mineralogic layer as well as the top of the pre-Tertiary surface were recorded (Appendix B) and the thickness of each zone calculated. The resulting thickness data were plotted on a base map of Yucca Flat consisting of a color elevation relief map of the pre-Tertiary surface based on gravity (Phelps et al., 1999 ) with basin faults from the draft Yucca Flat CAU framework model (Drellack and Gonzales, 1998). The thickness data for each mineralogic layer were hand-contoured to produce isopach maps showing the extent and thickness of the layers beneath Yucca Flat. Thickness contours were digitized and transferred to a shaded relief map of the land surface in the Yucca Flat vicinity for final presentation. 


\subsection{Mineralogic Zones}

Zeolite, felsic minerals (quartz, potassium-feldspar [K-feldspar], and plagioclase), and clay minerals account for approximately 90 percent of the TCU mineralogy based on XRD data from the TCU study holes (Figure 3-1). Zeolite is the most abundant mineral averaging 41 percent, followed closely by felsic minerals at 35 percent and clay minerals considerably less at 15 percent. A plot of the percentages of the 3 major mineral assemblages with respect to sample depth shows that the relative abundances of these minerals change with depth and define a 3-layer model of major mineral distribution within the TCU (Figure 3-2). The amount of zeolite appears to decrease in abundance with depth whereas both felsic and clay minerals increase. At the deepest levels, clay minerals dramatically increase whereas zeolite and felsic minerals decrease. These mineralogical changes can be grouped into 3 zones: (1) an upper zone dominated by the zeolite mineral clinoptilolite (ZC) with lesser amounts of felsic minerals (FS) and clay minerals (AR) and generally represented by the formula ZC>>FS >>AR; (2) a middle zone with felsic minerals dominant over clinoptilolite and clay minerals (ZC $<\mathrm{FS}>>\mathrm{AR}$ ); and (3) a basal argillic zone with clay minerals dominant over felsic minerals and clinoptilolite ( $\mathrm{ZC}<<\mathrm{FS}<\mathrm{AR}$ ). The 3 zones are designated from highest to lowest as the $\mathrm{ZC}$ zone, FS zone, and AR zone. Figure 3-3 provides a graphical comparison of the major mineralogy of the three zones. Table 3-1 lists the various minerals that occur within each zone and their relative abundance.

The three mineralogical zones can be traced laterally beneath Yucca Flat as shown in Figure 3-4. The figure also shows that the depth relationships with respect to each zone (i.e., the ZC zone occurs above the FS zone and the AR zone occurs at the base of the Tertiary section) are consistent in each drill hole, and the occurrence of the zones is independent of elevation. This is particularly evident when comparing drill hole U3mh with U3cn5 in Figure 3-4. Although U3mh is structurally higher in elevation than U3cn5, all three zones are present in both holes.

\subsection{ZC Zone}

The top of the ZC zone in Yucca Flat typically corresponds to the top of the TCU, which is established at the level of pervasive zeolitization, a subsurface horizon that has been successfully recognized and mapped in Yucca Flat for many years. Therefore, the top of the ZC zone in most drill holes was available from several existing sources. A draft version of the drill hole database for the Yucca Flat hydrostratigraphic framework model (in progress) provided elevations for the top of the TCU for many Yucca Flat drill holes. This database was compiled from Drellack and 
This page intentionally left blank. 


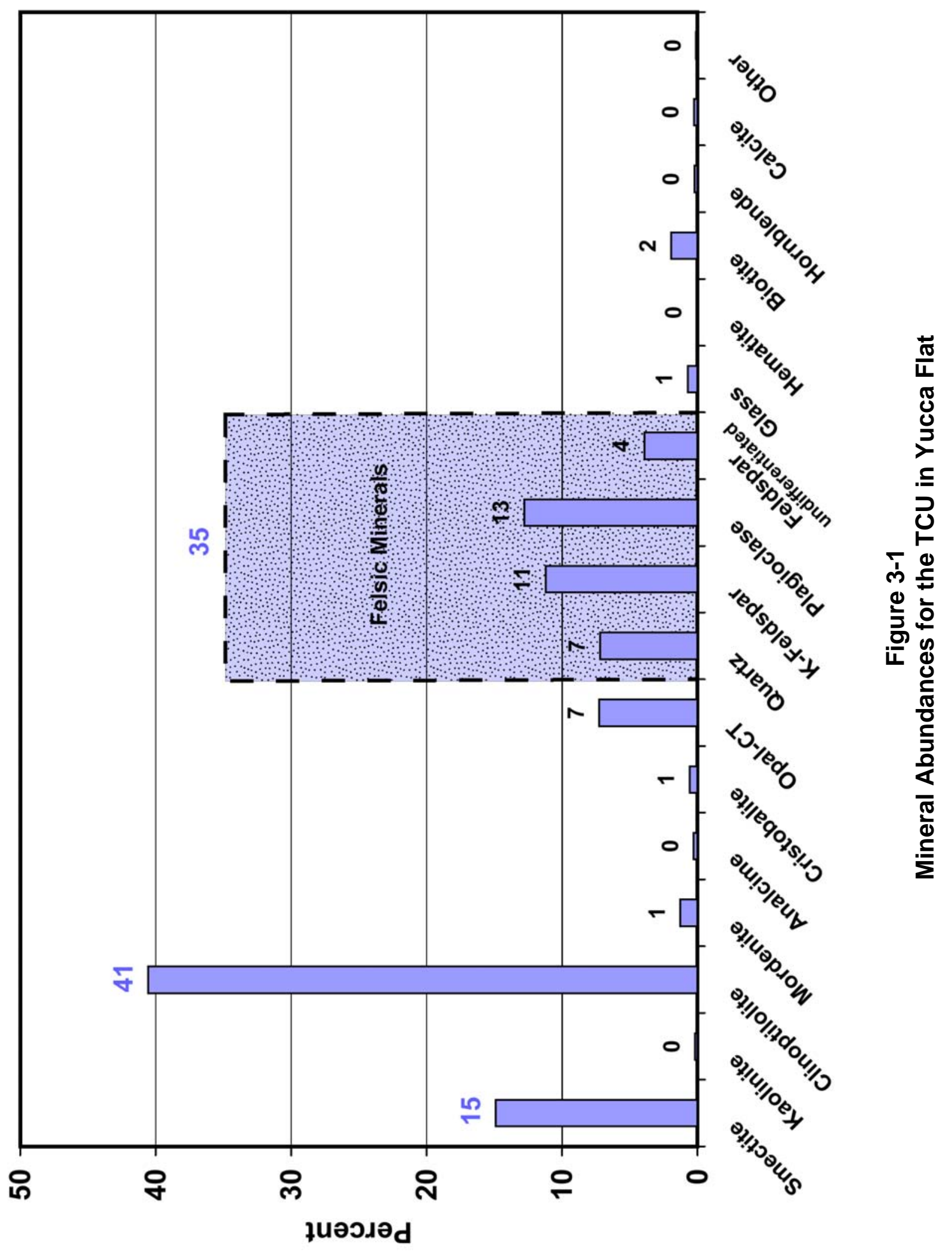


This page intentionally left blank. 


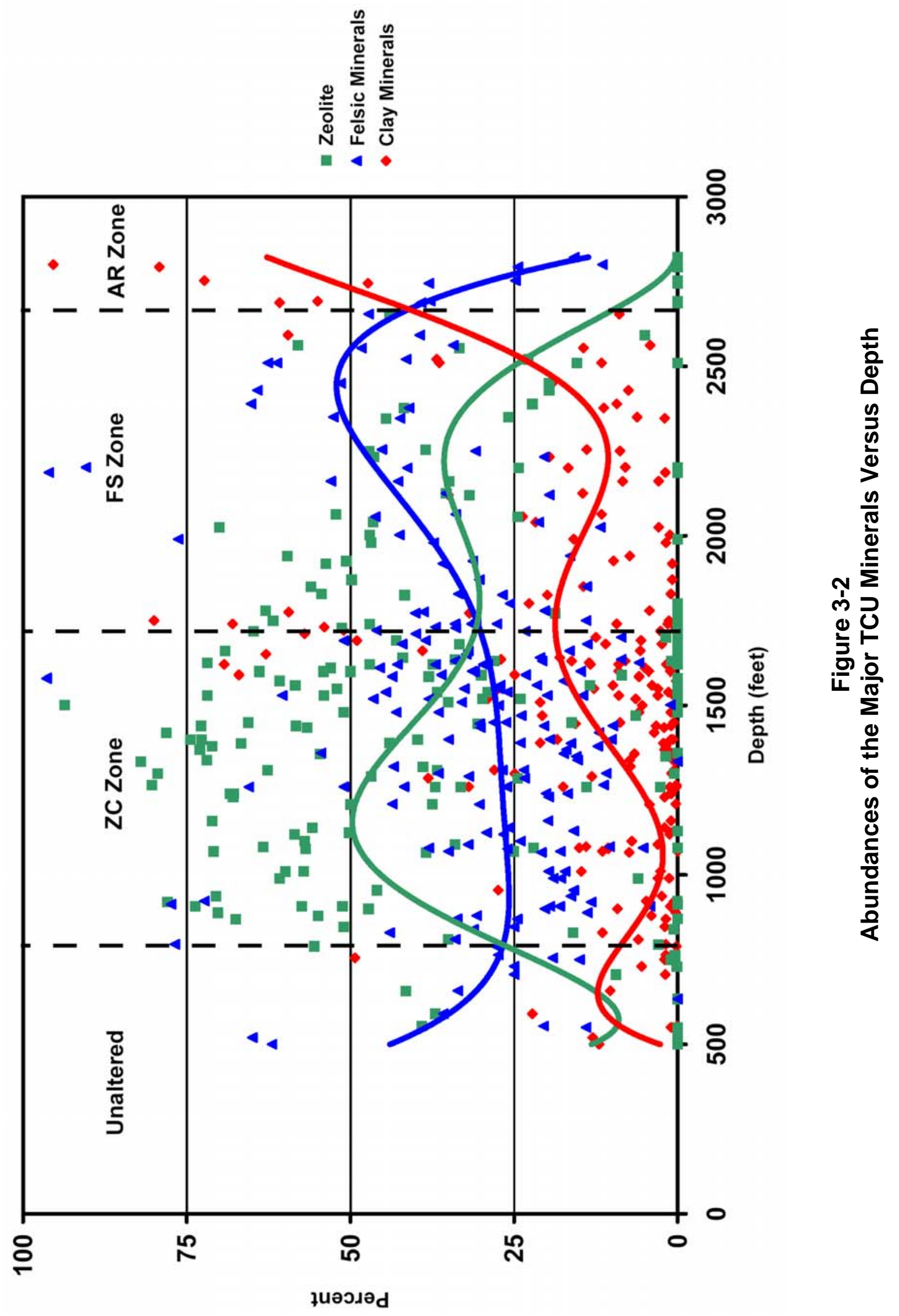


This page intentionally left blank. 


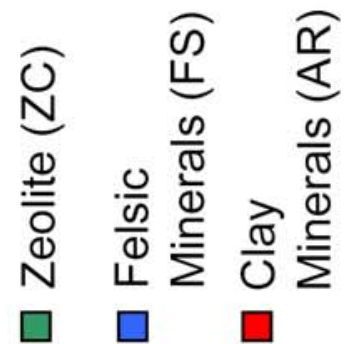

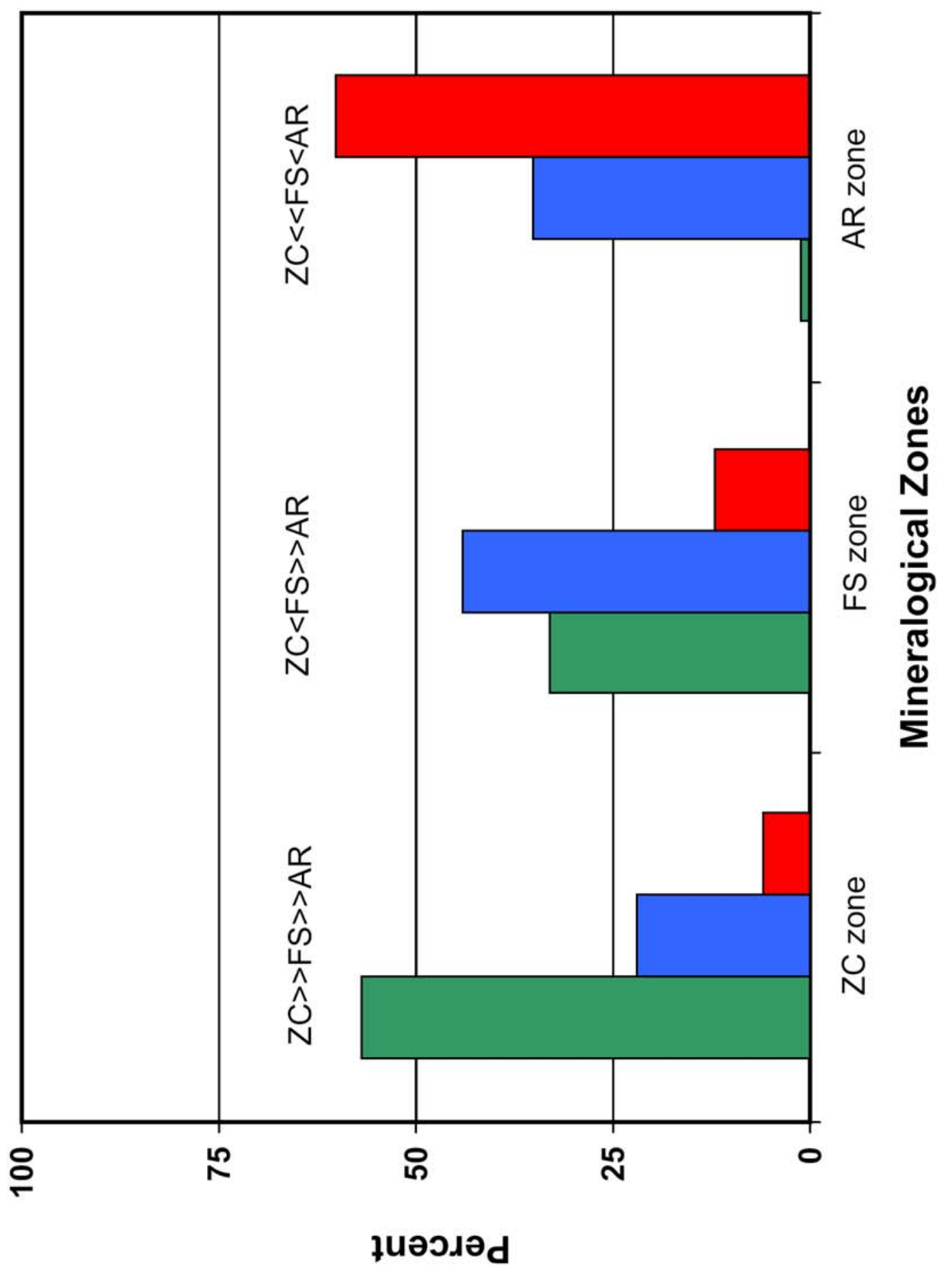

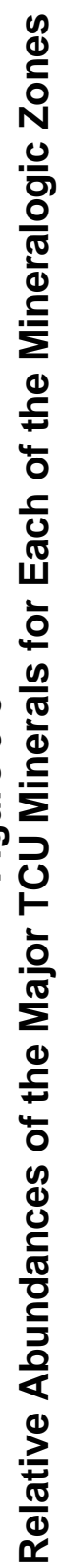


This page intentionally left blank. 
Table 3-1

List of Minerals and their Average Abundances for each TCU Mineralogic Zone

\begin{tabular}{|c|c|c|c|c|c|c|c|}
\hline \multirow{2}{*}{\multicolumn{2}{|c|}{ Mineral }} & \multicolumn{6}{|c|}{$\begin{array}{c}\text { Percent } \\
\text { (Standard Deviation) }\end{array}$} \\
\hline & & \multicolumn{2}{|c|}{$\begin{array}{c}\text { ZC Zone } \\
\mathrm{n}=81^{\mathrm{a}}\end{array}$} & \multicolumn{2}{|c|}{$\begin{array}{c}\text { FS Zone } \\
\mathrm{n}=49^{\mathrm{a}}\end{array}$} & \multicolumn{2}{|c|}{$\begin{array}{c}\text { AR Zone } \\
\mathrm{n}=20^{\mathrm{a}}\end{array}$} \\
\hline \multicolumn{2}{|c|}{ Smectite } & \multicolumn{2}{|c|}{$\begin{array}{c}\mathbf{6} \\
(7.9)\end{array}$} & \multicolumn{2}{|c|}{$\begin{array}{l}12 \\
(9.4)\end{array}$} & \multicolumn{2}{|c|}{$\begin{array}{c}\mathbf{5 8} \\
(14.7)\end{array}$} \\
\hline \multicolumn{2}{|c|}{ Kaolinite } & \multicolumn{2}{|c|}{$\begin{array}{l}<1 \\
(0.1)\end{array}$} & \multicolumn{2}{|c|}{$\begin{array}{l}<1 \\
(0.1)\end{array}$} & \multicolumn{2}{|c|}{$\begin{array}{c}1 \\
(2.1)\end{array}$} \\
\hline \multicolumn{2}{|c|}{ Clinoptilolite } & \multicolumn{2}{|c|}{$\begin{array}{c}\mathbf{5 4} \\
(16.1)\end{array}$} & \multicolumn{2}{|c|}{$\begin{array}{c}32 \\
(16.1)\end{array}$} & \multicolumn{2}{|c|}{$\begin{array}{c}\mathbf{1} \\
(2.2)\end{array}$} \\
\hline \multicolumn{2}{|c|}{ Mordenite } & \multicolumn{2}{|c|}{$\begin{array}{c}2 \\
(4.0)\end{array}$} & \multicolumn{2}{|c|}{$\begin{array}{c}\mathbf{1} \\
(1.4)\end{array}$} & \multicolumn{2}{|c|}{$\begin{array}{c}\mathbf{0} \\
(0.0)\end{array}$} \\
\hline \multicolumn{2}{|c|}{ Analcime } & \multicolumn{2}{|c|}{$\begin{array}{c}\mathbf{0} \\
(0.0)\end{array}$} & \multicolumn{2}{|c|}{$\begin{array}{c}\mathbf{1} \\
(3.2)\end{array}$} & \multicolumn{2}{|c|}{$\begin{array}{l}<1 \\
(0.6)\end{array}$} \\
\hline \multicolumn{2}{|c|}{ Cristobalite } & \multicolumn{2}{|c|}{$\begin{array}{c}1 \\
(0.9)\end{array}$} & \multicolumn{2}{|c|}{$\begin{array}{c}\mathbf{1} \\
(1.1)\end{array}$} & \multicolumn{2}{|c|}{$\begin{array}{c}\mathbf{0} \\
(0.0)\end{array}$} \\
\hline \multicolumn{2}{|c|}{ Opal-CT } & \multicolumn{2}{|c|}{$\begin{array}{c}10 \\
(6.3)\end{array}$} & \multicolumn{2}{|c|}{$\begin{array}{c}6 \\
(5.0)\end{array}$} & \multicolumn{2}{|c|}{$\begin{array}{c}\mathbf{0} \\
(0.0)\end{array}$} \\
\hline Quartz & \multirow{3}{*}{$\begin{array}{c}\text { Felsic } \\
\text { Minerals }\end{array}$} & $\begin{array}{c}3 \\
(2.6)\end{array}$ & \multirow{3}{*}{21} & $\begin{array}{c}10 \\
(8.8)\end{array}$ & \multirow{3}{*}{46} & $\begin{array}{c}17 \\
(6.6)\end{array}$ & \\
\hline K-Feldspar & & $\begin{array}{c}8 \\
(4.2)\end{array}$ & & $\begin{array}{c}17 \\
(9.0)\end{array}$ & & $\begin{array}{c}11 \\
(6.1)\end{array}$ & 34 \\
\hline Plagioclase & & $\begin{array}{c}10 \\
(5.0)\end{array}$ & & $\begin{array}{c}19 \\
(6.9)\end{array}$ & & $\begin{array}{c}\mathbf{6} \\
(5.0)\end{array}$ & \\
\hline Gl & & & & & & & \\
\hline Hem & & & & & & & \\
\hline Bic & & & & & & & \\
\hline Hornk & nde & & & & & & \\
\hline $\mathrm{Ca}$ & & & & & & & \\
\hline Dolc & & & & & & & \\
\hline
\end{tabular}

a Older analyses for U3mh and U3mi did not distinguish between the feldspar minerals plagioclase and K-feldspar; therefore, the population number $(n)$ is less for these minerals.

(ZC $n=70 ;$ FS $n=40 ;$ AR $n=13$, for plagioclase and K-feldspar) 
This page intentionally left blank. 


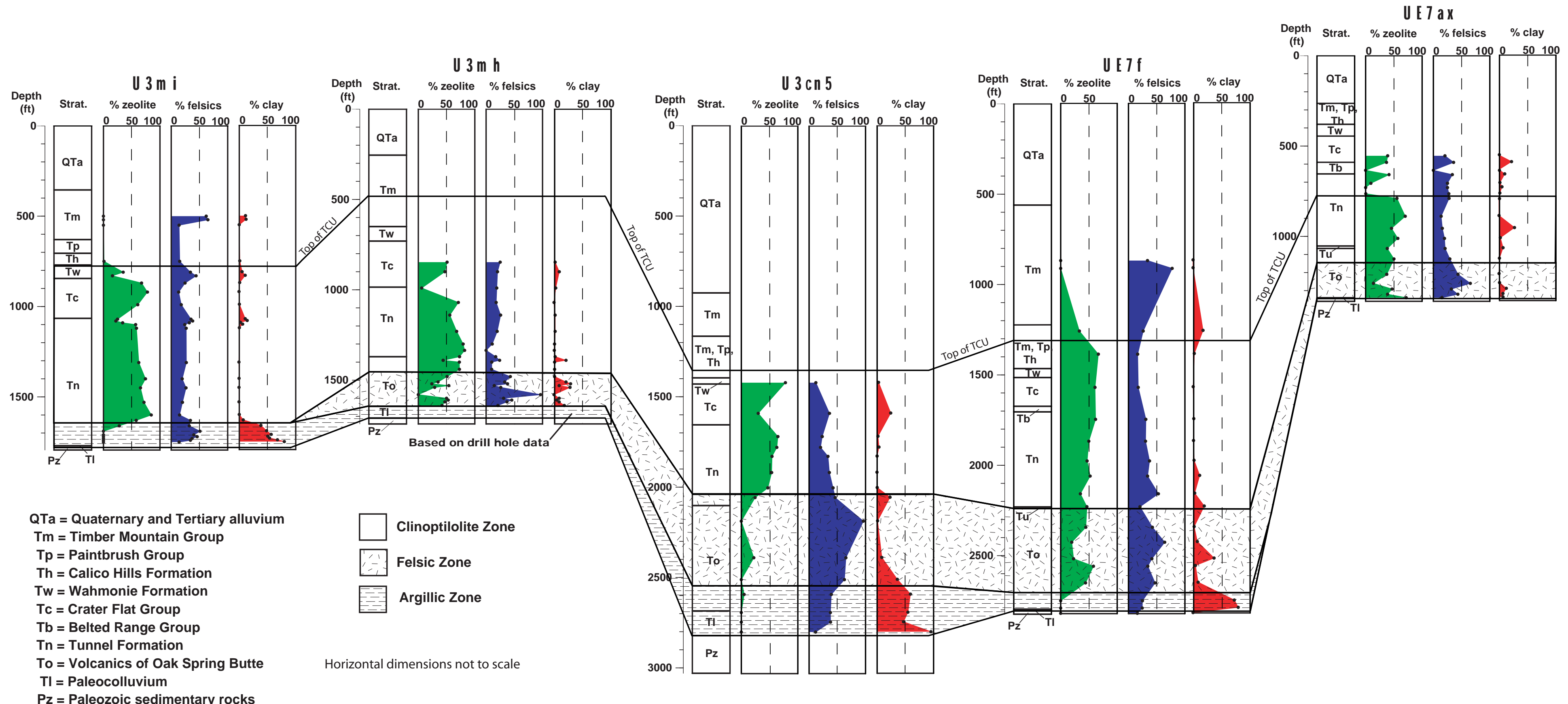

Figure 3-4

Cross-Sectional Diagram Through Drill Holes U $3 \mathrm{mi}, \mathrm{U} 3 \mathrm{mh}$, U3cn5, UE7f, and UE7ax Showing Mineralogic Zones Within the TCU 
This page intentionally left blank. 
Thompson (1990) for drill holes in southern Yucca Flat and unpublished data for northern Yucca Flat drill holes provided by LLNL (Pawloski, 1997, written communication). Additional information on the top of the ZC zone was gleaned from lithologic descriptions.

The approximate depth at which zeolitization becomes pervasive is relatively easy to determine in drill holes using lithologic samples and geophysical logs, particularly the epithermal neutron $\log$ (Drellack, 1994, written communication). The transition from unaltered vitric tuff to zeolitic tuff is typically rather abrupt but may occur over a considerable interval characterized by interbedded vitric and zeolitic intervals (e.g., see UE7ax in Figure 3-4 and Appendix B).

\subsubsection{Mineralogy of the ZC Zone}

The clinoptilolite zone is defined mineralogically by zeolite dominant over felsic minerals and both being much greater in abundance than clay minerals. Other minerals that were identified within the zone include opal-cristobalite/tridymite (CT), cristobalite, biotite, hornblende, and calcite.

\section{Zeolite}

The ZC zone averages 54 percent clinoptilolite based on the 81 samples analyzed for this study. However, locally the amount of clinoptilolite can range from less than 30 percent to more than 80 percent. The zeolite mordenite also occurs within the ZC zone. Twenty-four of the 80 samples analyzed contain mordenite, typically in amounts less than 10 percent but as high as 17 percent. Typically, but not exclusively, mordenite occurs in the lower portions of the ZC zone. The zeolite analcime was not detected in any of the ZC samples. The amount of zeolite within the ZC zone typically decreases slightly with depth.

\section{Felsic Minerals}

Felsic minerals (quartz, K-feldspar, and plagioclase) on average account for 21 percent of the minerals within the ZC zone. Plagioclase is the most abundant felsic mineral, averaging 10 percent of the zone (48 percent of the felsic minerals), followed by K-feldspar at 8 percent (38 percent of the felsic minerals), and quartz at 3 percent (14 percent of the felsic minerals). In contrast to zeolite, the amount of felsic minerals within the ZC zone increases slightly with depth. 


\section{Clay Minerals}

Clay minerals account for 6 percent of the minerals within the ZC zone. Almost all samples contained at least trace ( $<1$ percent) amounts of clay minerals with 7 samples having between 20 and 38 percent clay minerals. Smectite is by far the dominant clay mineral within the ZC zone. Kaolinite was the only other clay mineral detected and that was in only one sample and at less than 1 percent.

\section{Other Minerals}

Of the remaining mineral constituents within the ZC zone, opal-CT is the most abundant, accounting for, on average, 10 percent of the ZC zone mineralogy. Like zeolite, opal-CT appears to decrease slightly in abundance with depth in the zone. Other minerals detected include biotite ( 2 percent), cristobalite ( 1 percent), and hornblende and calcite (each $<1$ percent). Although glass accounts for 1 percent of the mineralogy of the zone, only 2 samples contained glass. Both samples contained high proportions of glass (34 percent and 72 percent) and occur near the top of the ZC zone, and thus likely represent minor interbeds of vitric tuff within predominately zeolitic intervals. Hematite was not detected in any of the samples from the ZC zone.

\subsubsection{Stratigraphy and Lithology of the ZC Zone}

Depending on the level of zeolitization, the ZC zone can include stratigraphic units as young as the Rainier Mesa Tuff (11.6 Ma) and as old as Tub Spring Tuff (14.9 Ma) (Sawyer et al., 1994). Zeolitic rocks older than the Tub Spring Tuff such as the Volcanics of Oak Spring Butte are typically assigned to the underlying FS zone. The stratigraphic units of the ZC zone consist predominantly of nonwelded tuff in the form of ash-flow, ash-fall, and reworked tuffs. These volcanic deposits contain high proportions of glass shards when deposited, which are susceptible over time, to zeolitization in basin environments like Yucca Flat. Thus when zeolitized, this relatively consistent lithologic composition yields rocks with consistently high proportions of zeolite like that observed within the ZC zone. At the southern end of Yucca Flat, strongly welded Topopah Spring Tuff is intercalated within the upper portion ZC zone. Also, at the north end of Yucca Flat, strongly welded Tub Spring Tuff occurs at the base of the ZC zone.

\subsubsection{Extent and Thickness of the ZC Zone}

The ZC zone is thick and extensive beneath Yucca Flat basin proper (Figure 3-5). The zone does not appear to be present on the buried ridge beneath the western portion of Yucca Flat or in the western subbasin, mainly because of the scarcity of volcanic rocks as well as the lack of zeolitic alteration due to the relatively high structural elevation. Within Yucca Flat basin proper, the thickness of the ZC zone averages $213 \mathrm{~m}$ (700 ft) calculated from measured thicknesses in drill 


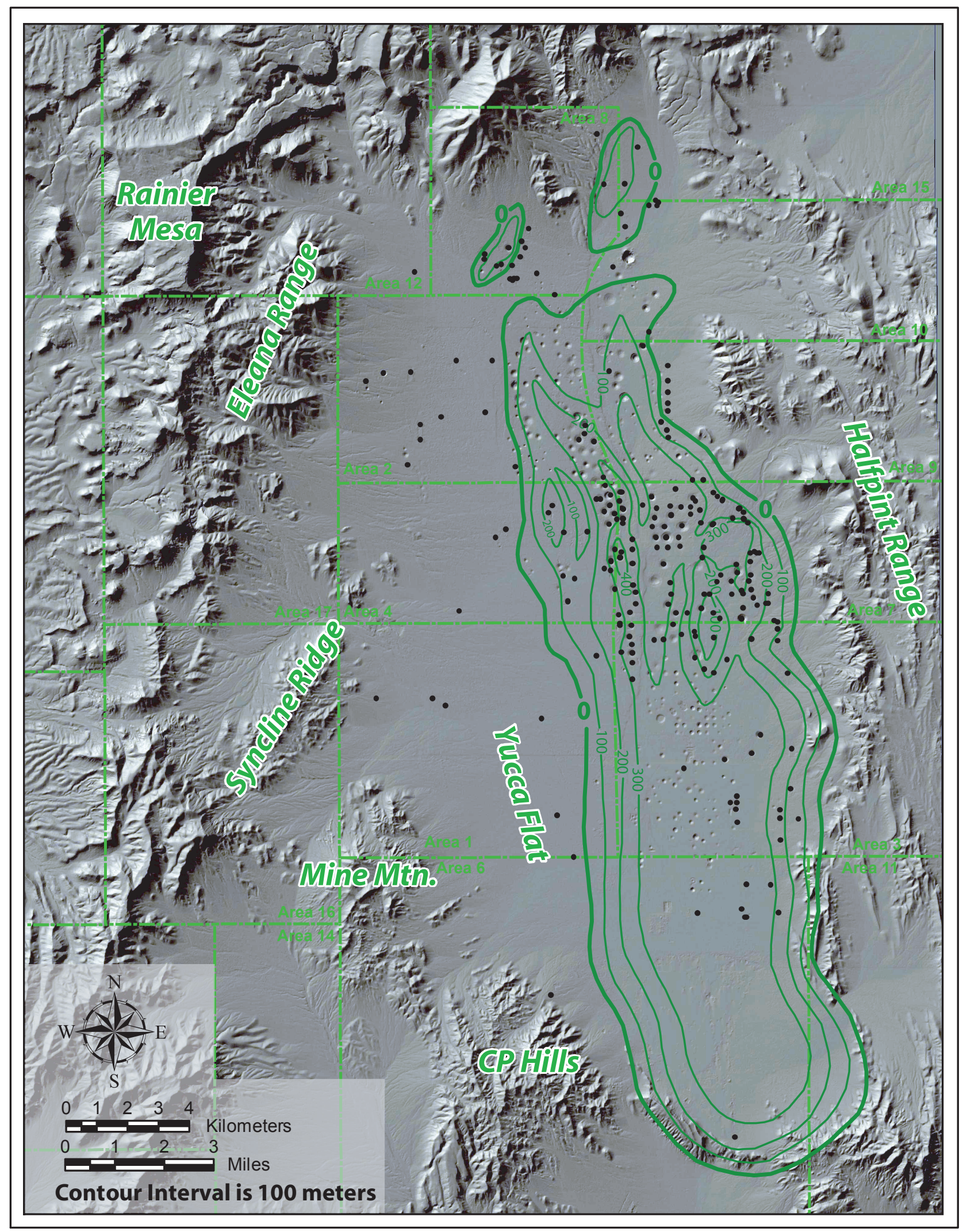

Figure 3-5

Isopach Map of the ZC Zone

Black dots show drill hole control. 
This page intentionally left blank. 
holes that penetrate a complete section of the zone. However, in north central Yucca Flat proper where the highest concentration of drill holes that encounter the zone are present, the thickness of the zone varies considerably from less than $100 \mathrm{~m}$ (329 ft) to more than $300 \mathrm{~m}(984 \mathrm{ft})$. The maximum measured thickness is $440 \mathrm{~m}(1,444 \mathrm{ft})$ at UE4f. The occurrence of more than $300 \mathrm{~m}$ (984 ft) of the ZC zone in drill holes UE6d\#3 and UE6e suggests that the ZC zone is also thick and extensive beneath southern Yucca Flat where few drill holes penetrate deep enough to encounter the zone. It appears that the zone thins toward the northern end of Yucca Flat basin proper due to the rise in elevation of the volcanic rocks and the subsequent lowering stratigraphically of the level of zeolitization as well as the erosion of post-Volcanics of Oak Spring Butte units during basin development.

\subsection{FS Zone}

Examination of Figure 3-4 indicates that although the occurrence of the FS zone seems independent of elevation, the thickness may be controlled by depth. For example, at U3cn5 and UE7f, the FS zone is much thicker than at U3mh and UE7ax which are considerably higher in elevation. However, a closer examination of the figure shows that the top of the FS zone is near the top of the Volcanics of Oak Spring Butte. A comparison of U3mi and U3mh reveals that although U3mi is lower in elevation than U3mh, the FS zone is not present in U3mi. However, the Volcanics of Oak Spring Butte are also not present in U3mi. Also, the Volcanics of Oak Spring Butte are much thicker in U3cn5 and UE7ax compared with U3mh and UE7ax. All this seems to indicate that the occurrence of the FS zone may be controlled more by stratigraphy than by elevation and depth. Based on lithologic descriptions and geophysical logs, the Volcanics of Oak Spring Butte and older Tertiary units in Yucca Flat include a more diverse assemblage of lithologic units than the overlying units that compose the ZC zone. The lithologic composition of the FS zone is discussed in more detail in Section 3.2.2, but in general, lithologic units of the FS zone contain more felsic-rich units such as devitrified welded ash-flow tuff and tuffaceous sandstone. Thus the amount of original glass available for zeolitization is less within the FS zone, resulting in a general decrease in the amount of zeolite within the zone as reflected in the XRD data.

It is possible that some of the higher felsic mineral contents observed within the FS zone are the result of higher temperature quartzo-feldspathic or hydrothermal alteration (Prothro and Warren, 2001). However, substantial amounts of low-temperature alteration minerals such as clinoptilolite are present throughout the FS zone. Results of oxygen isotope analyses of whole rock samples from the FS zone in UE7f are consistent with these low-temperature alteration minerals found within the FS zone in UE7f (Dickerson et al., 2004). In addition, stable isotope analyses of calcite 
lining fractures within the TCU beneath Yucca Flat indicate that the calcite formed at temperatures less than 100 degrees Celsius. Also, many calcite veins show a pedogenic carbon signature indicating that calcite within the TCU was deposited by groundwater moving downward and not upward through Paleozoic carbonate rocks as would be expected with hydrothermal activity (Dickerson et al., 2004).

As a first approximation, the top of the FS zone was determined in drill holes lacking mineralogic analyses by identifying the top of the Volcanics of Oak Spring Butte using existing stratigraphic and lithologic information. For the vast majority of holes, this method yielded a correct top for the FS zone because the level of zeolitization was stratigraphically above the Volcanics of Oak Spring Butte. However, in a few drill holes the level of zeolitization was within the Volcanics of Oak Spring Butte, and in these cases the top of the FS zone was picked at the top of zeolitization.

\subsubsection{Mineralogy of the FS Zone}

The FS zone is defined by felsic minerals generally more abundant than zeolite, with both more abundant than clay minerals. However, the mineralogic variability within the FS zone is greater than that for the ZC and AR zones.

\section{Zeolite}

Although felsic minerals are the most abundant mineral constituents of the FS zone, zeolite still constitutes a significant portion of the zone, averaging 34 percent of the mineral composition. Like the ZC zone, clinoptilolite is by far the dominant zeolite mineral within the FS zone, accounting for, on average, 32 percent of the zone mineralogy. However, clinoptilolite abundance within the zone ranges from 0 to more than 70 percent, reflecting the mineralogic variability that is characteristic of the zone.

Other zeolite minerals that occur within the zone include mordenite and analcime. Eight of the 49 samples analyzed from the FS zone contain mordenite. All 8 samples contain less than 7 percent mordenite, producing an average of 1 percent for the zone overall. Six samples contain analcime, all less than 10 percent except for one sample in UE7f that contains 20 percent analcime. Overall, the average amount of analcime within the FS zone is 1 percent.

\section{Felsic Minerals}

Forty-six percent of the minerals of the FS zone consist of the felsic minerals quartz, K-feldspar, and plagioclase. Like the ZC zone, the most abundant felsic mineral in the FS zone is plagioclase at 19 percent, followed by K-feldspar at 17 percent, and quartz at 10 percent. 


\section{Clay Minerals}

Although clay minerals are more abundant in the FS zone than in the ZC zone, they are still a rather minor constituent within the FS zone where they constitute on average 12 percent of the mineralogy. This is almost exclusively in the form of smectite with only one sample showing trace amounts of kaolinite. Although averaging only 12 percent, smectite abundance ranges from 0 to as high as 37 percent in the samples analyzed.

\section{Other Minerals}

Other minerals detected in samples from the FS zone include opal-CT (6 percent), biotite (3 percent), cristobalite (1 percent), and trace amounts of hematite, hornblende, and calcite. No glass was detected in any of the samples from the FS zone.

\subsubsection{Stratigraphy and Lithology of the FS Zone}

The top of the FS zone typically corresponds to the highest zeolitic unit within the Volcanics of Oak Spring Butte or older Tertiary rocks. Thus the zone can include all stratigraphic units from the top of the Volcanics of Oak Spring Butte to the top of pre-Tertiary rocks. This interval contains a more diverse assemblage of lithologic units than those that compose the overlying ZC zone. In addition to nonwelded tuffs, rocks of the FS zone include welded ash-flow tuff, tuffaceous sandstone, and paleocolluvium. This more diverse lithologic composition is reflected in a more variable mineralogy. Rocks deposited with high proportions of felsic minerals either through mechanical processes (e.g., tuffaceous sandstone) or devitrification (e.g. welded ashflow tuff) will have lower relative proportions of glass that can be altered to zeolite minerals.

\subsubsection{Extent and Thickness of the FS Zone}

Because the FS zone consists of zeolitized Volcanics of Oak Spring Butte and older Tertiary units, the extent and thickness of the zone is controlled mainly by the distribution of the Volcanics of Oak Spring Butte and older rocks, but also by the level of zeolitization. In the Yucca Flat basin proper, the FS zone is thick and extensive (Figure 3-6). The average thickness of the zone is $126 \mathrm{~m}$ (413 ft) calculated from measured thicknesses in drill holes that encountered a complete section of the zone. However, the thickness appears to be highly variable, ranging from a few tens of meters to more than $300 \mathrm{~m}(984 \mathrm{ft})$. This variability is likely due to pre-eruption topography and the degree of development (i.e., elevation) of the underlying argillic zone. Some of the variability may be apparent, resulting from portions of the older volcanic rocks being faulted out in some drill holes. The greatest thickness of FS zone 
This page intentionally left blank. 


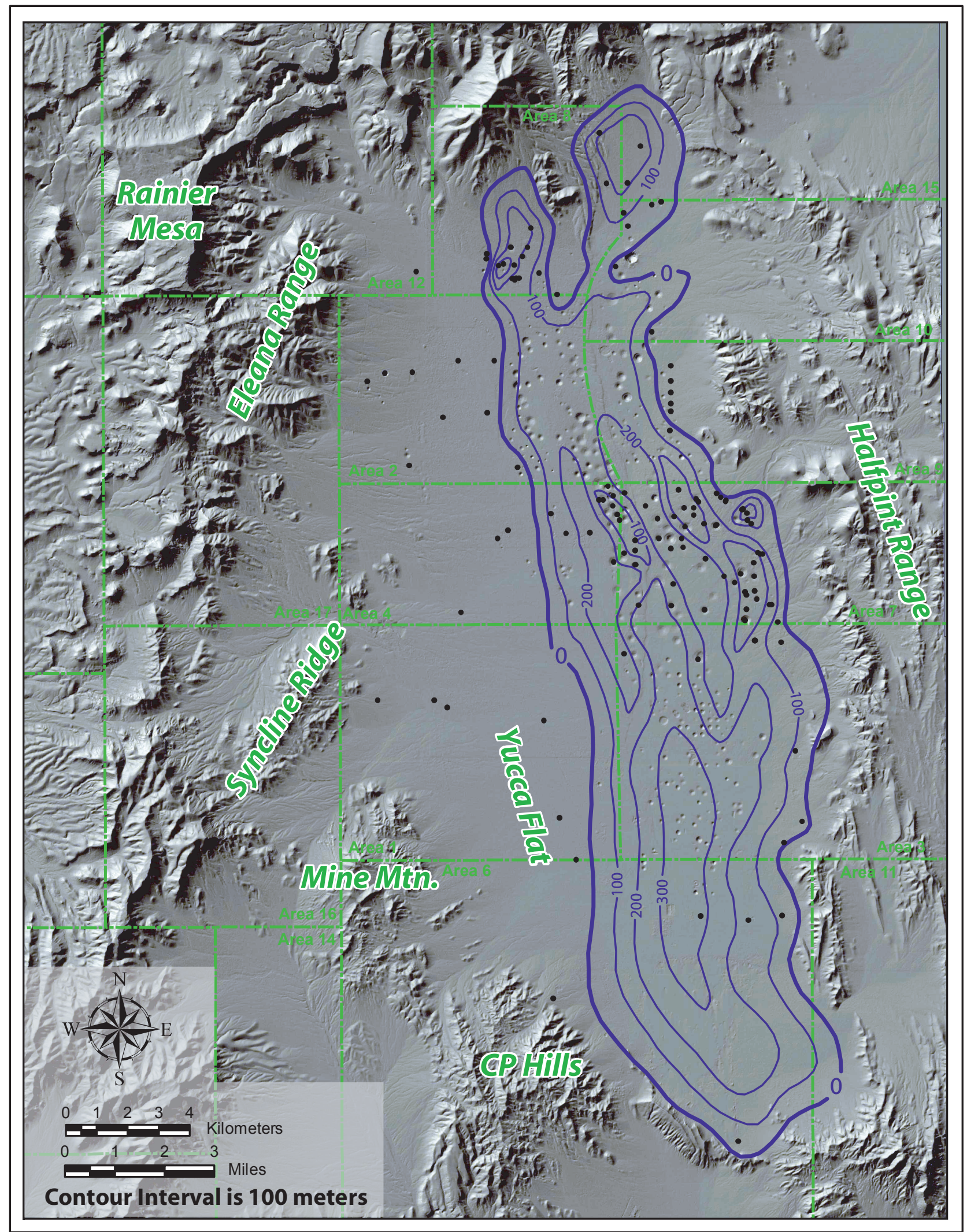

Figure 3-6

Isopach Map of the FS Zone

Black dots show drill hole control. 
This page intentionally left blank. 
encountered in a drill hole in Yucca Flat is $313 \mathrm{~m}(1,027 \mathrm{ft})$ at UE6e, suggesting that the FS zone is thick and extensive beneath southern Yucca Flat where few drill holes penetrate deep enough to encounter the zone. Similarly, thick (> $200 \mathrm{~m}$ [> $656 \mathrm{ft}]$ ) occurrences of FS zone in the central and extreme northern portions of Yucca Flat proper suggest that the FS zone is also relatively thick and extensive in eastern portions of Area 2 and western portions of Area 9 of northern Yucca Flat where existing drill hole information is insufficient to determine the thickness of the zone.

The FS zone is not present on the buried ridge where volcanic rocks are generally absent. The zone is also not present in the western sub-basin due to the lack of zeolitic alteration in the area, though older volcanic units are present.

\subsection{AR Zone}

Geologists working in Yucca Flat have known for decades that in many places beneath the basin the volcanic rocks at the base of the Tertiary section are highly argillized (Hoover, 1968; Drellack, 1994, written communication). The top of the AR zone is defined as the level below which almost all the rocks are pervasively argillic down to the top of the pre-Tertiary rocks. Other zones of pervasive argillic alteration occur throughout the volcanic section. Some of these zones intercepted by drill holes represent argillization along faults (Drellack, 1994, written communication). Others occur at the top of welded ash-flow tuffs such as the Redrock Valley Tuff. Although these argillic zones can be traced laterally for some distance beneath Yucca Flat, they are relatively thin and separated by significant intervals of non-argillic rocks, so they are not included within the AR zone. Many of these argillic zones occur within the FS zone and contribute to the characteristic mineralogic variability of the FS zone.

The pervasive argillic alteration of the AR zone has distinguishing characteristics that are readily observed macroscopically in lithologic samples and with geophysical logs. The argillic rocks tend to be darker in color than the overlying zeolitic rocks, exhibiting characteristic shades of red and brown that typically become darker with depth (Figure 3-7). Core segments from the argillic zone are typically moderately indurated to friable, with a decrease in induration with depth that is probably due to a systematic increase in argillization with depth through the zone. Core segments from the lower portion of the zone are typically highly broken, with waxy slickensided partings common. The outer surfaces of core segments from the AR zone are conspicuously rough in appearance and feel. This contrasts sharply with the much smoother surfaces of core 
This page intentionally left blank. 


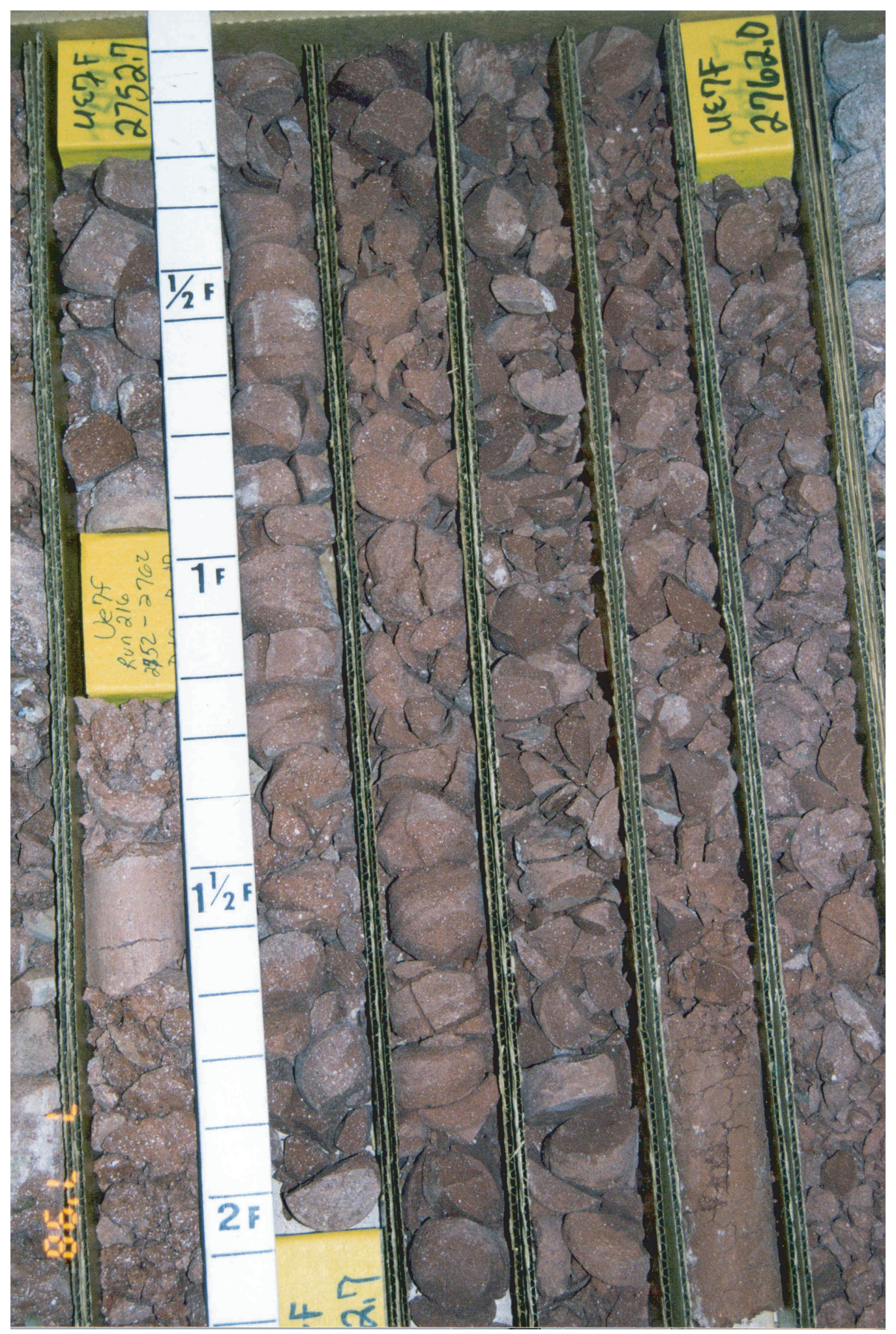

Figure 3-7

Photograph of Argillic Rocks in Drill Hole UE7f 
This page intentionally left blank. 
segments from overlying zones. Also, many core segments from the AR zone have a thin mudcake adhering to the sides of the core. This results from mud being generated during coring of the argillic rocks. The rocks of the AR zone also exhibit characteristic signatures on geophysical logs. Highly argillic tuffs typically exhibit resistivities of less than 10 ohm-meters, which is considerably less than zeolitic tuffs (Carroll, 1990), and thus can usually be identified with electric logs (Figure 3-8). Also, zones of pervasive argillic alteration tend to be less stable during drilling than zones of zeolitic alteration, resulting many times in conspicuous borehole enlargements that are easily identified on caliper logs. These characteristics permit the confident identification of the AR zone in numerous drill holes lacking sufficient mineralogic data.

\subsubsection{Mineralogy of the AR Zone}

The mineralogy of the AR zone is characterized by abundant clay, moderate amounts of felsic minerals, and the virtual absence of zeolite.

\section{Zeolite}

Zeolite minerals are rare in the AR zone, averaging approximately 1 percent. However, only 3 of the 20 samples analyzed from the AR zone contain zeolite, and all of these were in abundances less than 10 percent. Clinoptilolite was detected in 2 of the samples and analcime in 1. Mordenite was not detected.

\section{Felsic Minerals}

The felsic mineral content of the AR zone is substantial, averaging 34 percent. The relative abundances of the individual felsic minerals within the AR zone differ from the other 2 zones. Within the AR zone quartz is the most abundant felsic mineral, averaging 17 percent. K-feldspar is the second most abundant, averaging 11 percent, followed by plagioclase at 6 percent.

\section{Clay Minerals}

The AR zone averages 59 percent clay minerals. As in the other zones, smectite is the dominant clay mineral in the AR zone. It accounts for 58 percent of the mineralogy of the zone, with kaolinite averaging 1 percent. Smectite was detected in all the samples analyzed from the zone and in abundances greater than 30 percent. Kaolinite was detected in 6 of the 20 samples, in abundances of 6 percent or less.

\section{Other Minerals}

Biotite was detected in almost all the samples, averaging 2 percent for the zone. Calcite and dolomite were detected in a few of the samples, resulting in an average for the zone of 1 percent 
This page intentionally left blank. 


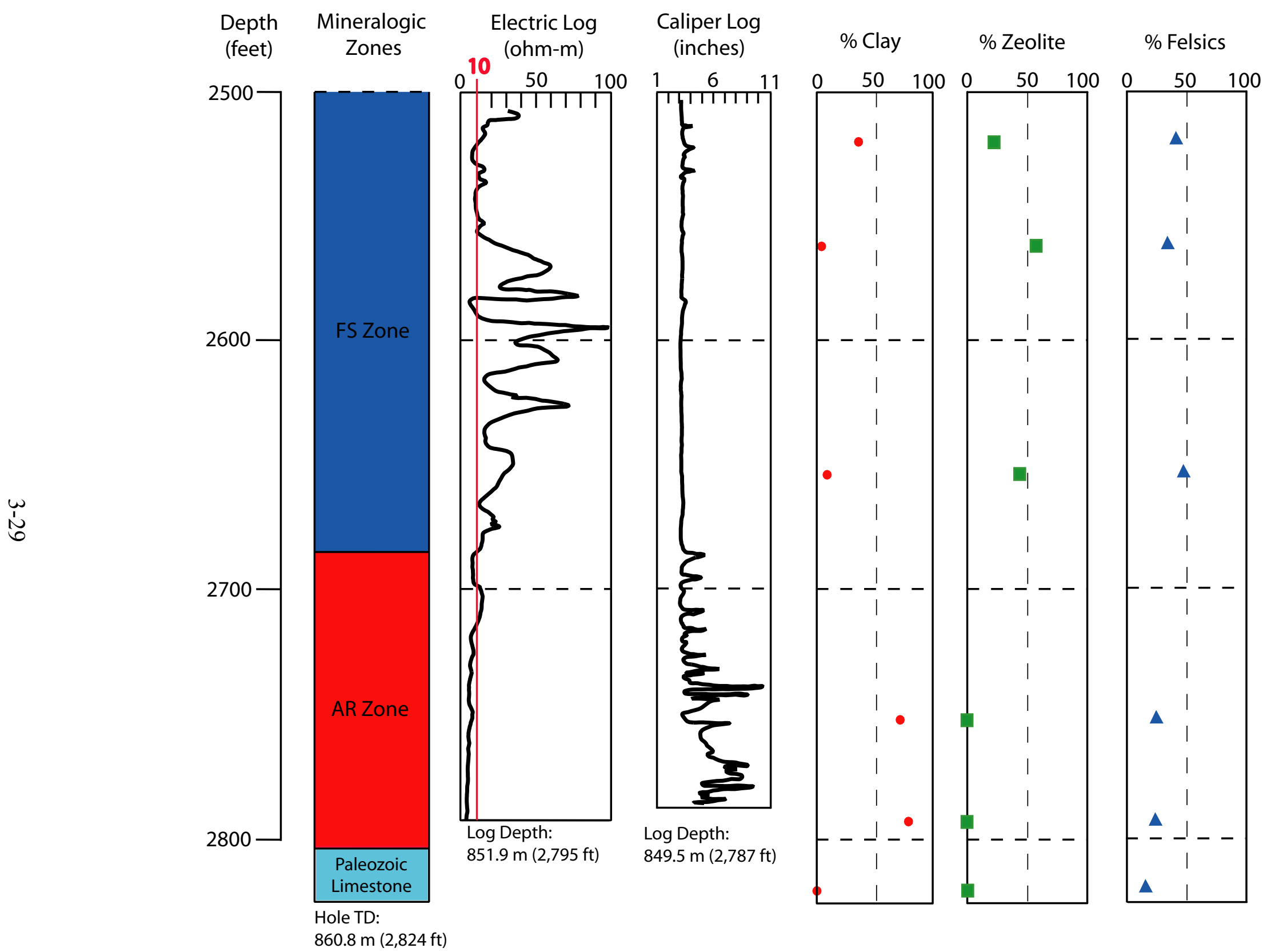

Figure 3-8

Diagram of Drill Hole UE7f showing Relationships Between the Electric Log, Caliper Log, and Clay Content 
This page intentionally left blank. 
each for both minerals. Hematite occurs in 9 of the 20 samples but always less than 2 percent, and resulting in an average for the zone of less than 1 percent. However, this is still the most abundant occurrence of hematite of the three zones. No cristobalite, opal-CT, glass, or hornblende was detected in any of the samples from the AR zone.

\subsubsection{Stratigraphy and Lithology of the AR Zone}

Because the AR zone forms at the base of the Tertiary section directly overlying the pre-Tertiary surface, the zone typically includes the oldest Tertiary stratigraphic units in the Yucca Flat vicinity. Consequently, the AR zone contains many of the same stratigraphic and lithologic units as the FS zone.

\subsubsection{Extent and Thickness of the AR Zone}

The AR zone is present in both the Yucca Flat basin proper and the western sub-basin but appears to be absent on the buried ridge (Figure 3-9). Within basin areas, the AR zone appears to be rather ubiquitous, with an average thickness calculated from drill hole intercepts of $27 \mathrm{~m}$ $(89 \mathrm{ft})$. The zone typically ranges in thickness from a few meters to more than $100 \mathrm{~m}$ (328 ft). Although variable, the thickness of the AR zone rarely exceed $60 \mathrm{~m}(197 \mathrm{ft})$. However at drill hole UE4af in the western sub-basin, $202 \mathrm{~m}$ (663 ft) of the argillic tuffs are present. This is by far the greatest thickness of the AR zone reported and may represent argillization along a high angle fault near the UE4af borehole. 
This page intentionally left blank. 


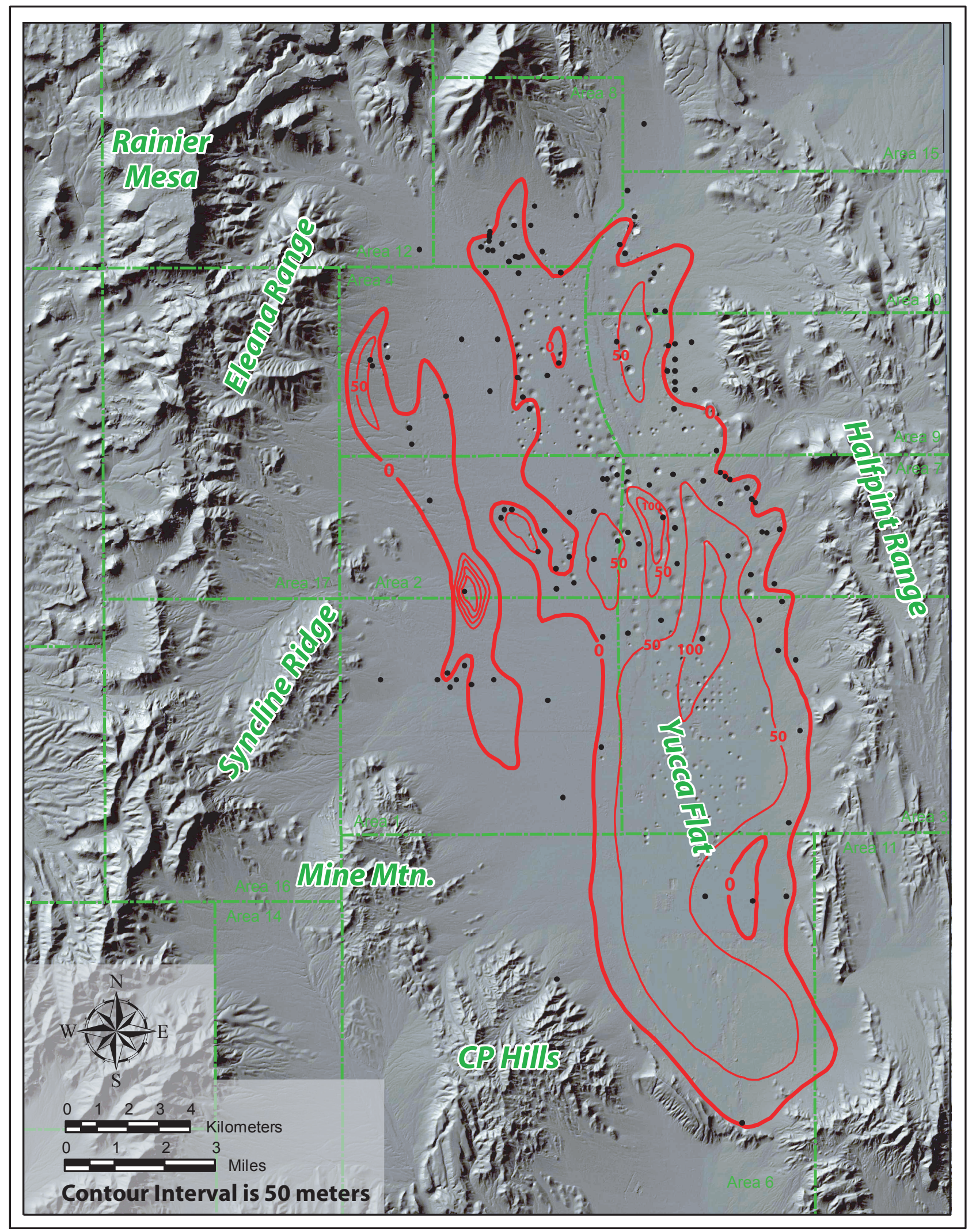

Figure 3-9

Isopach Map of the AR Zone

Black dots show drill hole control. 
This page intentionally left blank. 


\subsection{Summary}

Altered volcanic rocks that form the TCU beneath Yucca Flat consist mainly of 3 major mineral assemblages: zeolite, felsic minerals, and clay minerals. Based on these three mineral assemblages, the TCU can be subdivided into 3 zones representing differences in the abundance of these mineral asemblages. This three-layer model includes: (1) an upper zone called the ZC zone that is characterized by the abundance of the zeolite mineral clinoptilolite with lesser amounts of felsic and clay minerals; (2) a middle zone called the FS zone with felsic minerals dominant over clinoptilolite and clay minerals; and (3) a basal argillic zone called the AR zone where clay minerals are dominant over felsic minerals and clinoptilolite.

All 3 zones are extensive beneath the eastern half of Yucca Flat within the Yucca Flat basin proper. Only the AR zone occurs beneath western Yucca Flat within the western sub-basin. All 3 zones appear to be absent along the buried ridge that separates Yucca Flat basin proper from the western sub-basin. The ZC zone is, on average, the thickest of the 3 zones, averaging $213 \mathrm{~m}$

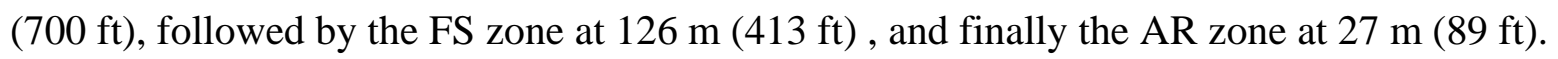

The three-layer mineralogic model of the TCU will provide additional hydrostratigraphic layers for the Yucca Flat hydrostratigraphic framework model. In addition, the identification of the type, quantity, and distribution of alteration minerals within each TCU layer will permit modelers to better predict the spatial distribution and extent of contaminant transport from underground tests in Yucca Flat, at both the hydrologic source term and CAU-level scales. 
This page intentionally left blank. 


\subsection{References}

Carroll, R. D. 1990. Electric Logging and Electrical Properties of Rocks in Rainier Mesa Area, Nevada Test Site, Nevada. U.S. Geological Survey Open-File Report 90-31, 90 p.

Drellack, S. L., Jr., 1994. Unpublished Raytheon Services Nevada report describing NTS Geology and Geophysical Log Characteristics.

Drellack, S. L., Jr. and J. L. Gonzales, 1998. Unpublished drill hole database for the draft Yucca Flat CAU hydrostratigraphic model.

Drellack, S. L., Jr. and P. H. Thompson, 1990. Selected Stratigraphic Data for Drill Holes in LANL Use Areas of Yucca Flat, NTS. DOE/NV-10322-39. Las Vegas, NV: Fenix \& Scisson, Inc.

Dickerson, R. P., T. P. Rose, and G. F. Eaton, 2004. Mineralogic and Isotopic Analysis of Fracture-Coating and Alteration Minerals in the Yucca Flat Tuff Confining Unit, Nevada Test Site. Lawrence Livermore National Laboratory UCRL Report (in progress).

Hoover, D. L. 1968. Genesis of Zeolites, Nevada Test Site. In: Eckel, E. B., editor. Nevada Test Site, Geological Society of America Memoir 110. Boulder, CO.

Pawloski, G. A., 1997. Unpublished stratigraphic information for drill holes in LLNL use areas in Yucca Flat.

Phelps, G. A., V. E. Langenheim, and R. C. Jachens, 1999. Thickness of Cenozoic Deposits of Yucca Flat Inferred from Gravity Data, Nevada Test Site, Nevada. U. S. Geological Survey Open-File Report 99-310, 33 p.

Prothro, L. B., 2000. Unpublished Bechtel Nevada Fiscal Year 2000 status report for the Yucca Flat TCU study.

Prothro, L. B., B. M. Allen, R. G. Warren, and G. A. Pawloski, 1999. Unpublished Bechtel Nevada Fiscal Year 1999 status report for the Yucca Flat TCU study.

Prothro, L. B. and R. G. Warren, 2001. Geology in the Vicinity of the TYBO and BENHAM Underground Nuclear Tests, Pahute Mesa, Nevada Test Site. Bechtel Nevada Report DOE/NV/11718-305.

Sawyer, D. A., R. J. Fleck, M. A. Lanphere, R. G. Warren, D. E. Broxton, and M. R. Hudson, 1994. Episodic Caldera Volcanism in the Miocene Southwest Nevada Volcanic Field: Revised Stratigraphic Framework, ${ }^{40} \mathrm{AR} /{ }^{39} \mathrm{AR}$ Geochronolgy, and Implications for Magmatism and Extension. Geological Society of America Bulletin, v. 67, n. 10, pp. $1304-1318$. 
Tompson, A. E., C. J. Bruton, and G. A. Pawloski, editors. 1999. Evaluation of the Hydrologic Source Term from Underground Nuclear Tests in Frenchman Flat at the Nevada Test Site: The CAMBRIC Test. Lawrence Livermore National Laboratory Report UCRL-ID-132300. Livermore, CA. 


\section{Appendix A}

\section{X-Ray Diffraction Results}


Results of XRD Analyses for TCU Study Samples

(XRD analyses performed by the Hydrology, Geochemistry, and Geology Group, Earth and Environmental Sciences Division, Los Alamos National Laboratory)

\begin{tabular}{|c|c|c|c|c|c|c|c|c|c|c|c|c|c|c|c|c|c|c|c|c|}
\hline & \multirow{2}{*}{$\begin{array}{c}\text { Sample } \\
\text { Depth (ft) }\end{array}$} & \multirow{2}{*}{$\begin{array}{c}\text { Mineralogic } \\
\text { Zone }^{1}\end{array}$} & \multicolumn{17}{|c|}{ Mineral Abundance (\%) } & \multirow{2}{*}{$\begin{array}{c}\text { Total } \\
(\%)\end{array}$} \\
\hline & & & SM & KA & ZC & ZM & ZA & CR & OP & $\mathbf{Q Z}$ & KF & $\mathbf{P L}$ & FE & $\overline{G L}$ & HM & BT & $\mathrm{HN}$ & CC & Other & \\
\hline \begin{tabular}{|c|} 
Drill Hole \\
TWC
\end{tabular} & 1260.6 & AR & 31.9 & --- & --- & --- & 2.6 & --- & --- & 25.0 & 15.0 & 11.0 & -- & --- & 1.2 & 2.8 & --- & 11.5 & --- & 100.9 \\
\hline UE2co & 1500 & na & 5.4 & --- & --- & --- & --- & 1.2 & --- & 0.6 & 11.5 & 15.2 & --- & 60.6 & --- & 0.9 & --- & 0.6 & Tridymite 2.3 & 98.3 \\
\hline UE2co & 1620 & na & 1.7 & --- & --- & --- & --- & --- & --- & 10.1 & 11.5 & 8.1 & --- & 68.8 & --- & 1.1 & 0.1 & --- & --- & 101.4 \\
\hline UE2co & 1680 & na & 2.4 & --- & --- & --- & --- & --- & --- & 1.4 & 5.5 & 6.9 & --- & 81.4 & --- & 1.1 & 0.1 & 0.2 & Dolomite 2.9 & $\overline{101.9}$ \\
\hline UE2co & 1740 & na & 1.5 & --- & --- & $\begin{array}{ll}-- \\
--\end{array}$ & --- & $\begin{array}{ll}-- \\
--\end{array}$ & --- & 0.1 & 9.8 & 17.7 & --- & 66.2 & --- & 1.6 & --- & --- & Illite? 3.1 & 100.0 \\
\hline UE2co & 1775 & AR & 59.4 & --- & --- & $\begin{array}{l}-- \\
--\end{array}$ & --- & --- & --- & 12.6 & 10.2 & 16.0 & --- & --- & --- & 5.6 & 1.0 & $\begin{array}{l}-- \\
--\end{array}$ & --- & 104.8 \\
\hline U3CN5 & 1420.3 & ZC & 3.6 & --- & 78.1 & --- & --- & --- & 5.9 & 0.8 & 5.3 & 5.9 & --- & --- & --- & --- & --- & --- & --- & 99.6 \\
\hline U3CN5 & 1590 & ZC & 24.9 & --- & 30.0 & --- & -- & --- & 3.8 & 4.1 & 8.8 & 23.2 & -- & --- & --- & 2.0 & -- & --- & --- & 96.9 \\
\hline U3CN5 & 1718.4 & $\overline{Z C}$ & 2.6 & --- & 64.8 & --- & -- & --- & 5.4 & 3.7 & 8.5 & 11.1 & -- & --- & --- & -- & -- & --- & --- & 96.2 \\
\hline U3CN5 & 1778.3 & ZC & 4.3 & --- & 62.9 & --- & --- & --- & 12.1 & 4.7 & 9.6 & 6.0 & --- & --- & --- & --- & --- & --- & --- & 99.6 \\
\hline U3CN5 & 1828.1 & ZC & 1.0 & --- & 52.9 & 1.5 & -- & --- & 3.4 & 3.7 & 8.7 & 21.1 & --- & --- & --- & 5.4 & 0.2 & --- & --- & 97.9 \\
\hline U3CN5 & 1917.5 & $Z C$ & 0.8 & --- & 50.9 & 2.8 & --- & --- & 2.3 & 4.3 & 16.2 & 15.4 & --- & --- & --- & 4.4 & --- & --- & --- & 97.4 \\
\hline U3CN5 & 2002.2 & $Z C$ & 1.2 & --- & 44.1 & 2.9 & --- & --- & 2.8 & 12.8 & 14.6 & 15.1 & --- & --- & --- & 4.2 & 1.1 & --- & --- & 98.7 \\
\hline U3CN5 & 2056 & FS & 23.0 & 0.7 & 19.2 & 5.2 & --- & --- & --- & 7.9 & 13.8 & 24.5 & --- & --- & --- & 4.0 & --- & --- & --- & 98.2 \\
\hline U3CN5 & 2186.4 & FS & 1.9 & --- & --- & --- & --- & --- & --- & 29.9 & 37.4 & 28.8 & --- & --- & 0.7 & 3.8 & --- & --- & --- & 102.5 \\
\hline U3CN5 & 2389 & FS & 9.3 & --- & 18.5 & 3.7 & --- & --- & --- & 17.9 & 25.2 & 22.1 & --- & --- & --- & 5.4 & --- & --- & --- & 102.1 \\
\hline U3CN5 & 2510 & AR & 36.4 & --- & --- & --- & --- & --- & --- & 22.0 & 28.7 & 11.9 & --- & --- & --- & 4.0 & --- & --- & --- & 103.0 \\
\hline U3CN5 & 2592 & AR & 59.5 & --- & 5.0 & --- & -- & --- & --- & 24.6 & 6.4 & 8.4 & -- & --- & -- & 1.0 & -- & --- & --- & 104.9 \\
\hline U3CN5 & 2692 & $\mathrm{AR}$ & 55.0 & --- & --- & --- & --- & --- & --- & 24.1 & 10.4 & 3.3 & --- & --- & 0.3 & 2.7 & --- & 3.0 & Dolomite 6.0 & 104.9 \\
\hline U3CN5 & 2745.1 & $\mathrm{AR}$ & 46.6 & 0.7 & --- & --- & --- & --- & --- & 21.0 & 15.5 & 1.5 & --- & --- & --- & 1.3 & --- & 1.3 & Dolomite 9.2 & 97.2 \\
\hline U3CN5 & 2800 & $\mathrm{AR}$ & 91.4 & 4.0 & --- & --- & --- & --- & --- & 4.1 & 7.3 & 0.1 & --- & --- & --- & 3.7 & --- & --- & --- & $\overline{110.6}$ \\
\hline $\mathrm{U} 3 \mathrm{MH}$ & 847 & ZC & 2.0 & --- & 51.0 & $\begin{array}{l}-- \\
--\end{array}$ & --- & --- & 21.0 & 6.0 & --- & --- & 19.0 & --- & --- & --- & --- & --- & --- & 99.0 \\
\hline U3MH & 900 & $Z C$ & 9.2 & --- & 47.2 & --- & --- & --- & 16.1 & 3.1 & 9.3 & 7.9 & --- & --- & --- & 5.5 & 0.6 & --- & --- & 98.9 \\
\hline $\mathrm{U} 3 \mathrm{MH}$ & 990 & $Z C$ & 3.0 & --- & 6.0 & --- & --- & --- & --- & 6.0 & --- & --- & 13.0 & 72.0 & --- & 0.5 & 0.5 & --- & --- & 101.0 \\
\hline $\mathrm{U} 3 \mathrm{MH}$ & 1070 & ZC & --- & --- & 70.9 & --- & -- & --- & 8.9 & 2.8 & 5.5 & 9.6 & --- & --- & --- & --- & 0.6 & --- & --- & 98.3 \\
\hline $\mathrm{U} 3 \mathrm{MH}$ & 1140 & $Z C$ & 2.0 & --- & 55.8 & --- & --- & --- & 12.7 & 5.9 & 10.5 & 9.4 & --- & --- & --- & --- & $\overline{---}$ & --- & --- & 96.3 \\
\hline $\mathrm{U} 3 \mathrm{MH}$ & 1230 & $\mathrm{ZC}$ & 2.0 & --- & 61.5 & 6.4 & --- & --- & 6.7 & 4.4 & 6.8 & 8.5 & --- & --- & --- & 0.3 & --- & --- & --- & 96.8 \\
\hline $\mathrm{U} 3 \mathrm{MH}$ & 1300 & $Z C$ & 0.9 & --- & 69.8 & 9.6 & --- & --- & 10.3 & 0.5 & 4.4 & 6.0 & --- & --- & --- & --- & 0.1 & --- & --- & 101.4 \\
\hline U3MH & 1335 & $Z C$ & 0.5 & --- & 82.0 & --- & --- & --- & 13.0 & --- & --- & --- & --- & --- & --- & 0.5 & --- & --- & --- & 96.0 \\
\hline $\mathrm{U} 3 \mathrm{MH}$ & 1370 & ZC & 2.0 & --- & 73.0 & --- & --- & --- & 12.0 & 2.0 & --- & --- & 15.0 & --- & --- & -- & --- & --- & --- & 104.0 \\
\hline $\mathrm{U} 3 \mathrm{MH}$ & 1390 & ZC & 21.0 & --- & 44.0 & --- & --- & --- & 4.0 & 3.0 & --- & --- & 21.0 & --- & --- & 1.0 & 0.5 & --- & --- & 94.5 \\
\hline $\mathrm{U} 3 \mathrm{MH}$ & 1400 & ZC & 1.0 & --- & 67.8 & 4.9 & --- & --- & 14.4 & 1.1 & 3.5 & 5.5 & --- & --- & --- & 2.2 & 0.5 & --- & --- & 100.9 \\
\hline U3MH & 1440 & ZC & 1.0 & --- & 67.9 & 4.9 & --- & --- & 14.3 & 1.1 & 3.4 & 5.4 & --- & --- & --- & 2.2 & 0.4 & --- & --- & 100.7 \\
\hline U3MH & 1480 & FS & 1.0 & --- & 51.0 & --- & --- & --- & 10.0 & 8.0 & --- & --- & 35.0 & --- & --- & 1.0 & 0.5 & --- & --- & 106.5 \\
\hline $\mathrm{U} 3 \mathrm{MH}$ & 1510 & $\mathrm{FS}$ & 21.0 & --- & 35.0 & --- & --- & --- & 4.0 & 6.0 & --- & --- & 27.0 & --- & --- & 1.0 & 0.5 & --- & --- & 94.5 \\
\hline U3MH & 1520 & $\mathrm{FS}$ & 29.0 & --- & 24.0 & --- & -- & --- & 4.0 & 5.0 & --- & --- & 33.0 & --- & --- & 0.5 & 0.5 & --- & --- & 96.0 \\
\hline U3MH & 1530 & FS & 9.0 & --- & 54.0 & --- & --- & --- & 19.0 & 0.5 & --- & --- & 14.0 & --- & --- & 0.5 & --- & --- & --- & 97.0 \\
\hline U3MH & 1540 & FS & 28.0 & --- & 29.0 & --- & --- & --- & 11.0 & 1.0 & --- & --- & 25.0 & --- & --- & 1.0 & --- & --- & --- & 95.0 \\
\hline U3MH & 1580 & FS & --- & --- & --- & --- & --- & --- & --- & 30.1 & 50.3 & 16.0 & --- & --- & 0.2 & 4.2 & --- & --- & --- & 100.7 \\
\hline U3MH & 1600 & FS & 9.0 & --- & 50.0 & --- & --- & --- & 12.0 & 0.5 & --- & --- & 30.5 & --- & --- & 0.5 & --- & -- & --- & 102.5 \\
\hline U3MH & 1610 & FS & 5.0 & --- & 53.0 & --- & --- & --- & 8.0 & 15.0 & --- & --- & 30.5 & --- & --- & 1.0 & 0.5 & --- & --- & 113.0 \\
\hline
\end{tabular}




\begin{tabular}{|c|c|c|c|c|c|c|c|c|c|c|c|c|c|c|c|c|c|c|c|c|}
\hline & Sample & Mineralogic & \multicolumn{17}{|c|}{ Mineral Abundance (\%) } & \multirow{2}{*}{$\begin{array}{c}\text { Total } \\
(\%)\end{array}$} \\
\hline Drill Hole & Depth (ft) & Zone $^{1}$ & SM & KA & ZC & ZM & ZA & CR & OP & QZ & $\mathrm{KF}$ & $\mathbf{P L}$ & $\mathrm{FE}$ & GL & HM & BT & HN & CC & Other & \\
\hline U3MH & 1620 & $\mathrm{FS}$ & 9.0 & $\overline{---}$ & 47.0 & --- & --- & --- & 7.0 & 8.0 & $\overline{---}$ & --- & 29.0 & --- & --- & 1.0 & $\overline{---}$ & $\overline{---}$ & --- & 101.0 \\
\hline $\mathrm{U} 3 \mathrm{MH}$ & 1640 & FS & 18.0 & --- & 42.0 & --- & --- & --- & 0.5 & 2.0 & --- & --- & 19.0 & --- & --- & 0.5 & --- & --- & --- & 82.0 \\
\hline U3MI & 500 & na & 12.0 & --- & --- & - & --- & 12.0 & --- & 13.0 & --- & --- & 49.0 & --- & 1.0 & 0.5 & --- & --- & Tridymite 9 & 96.5 \\
\hline U3MI & 520 & na & 13.0 & --- & --- & --- & --- & 25.0 & --- & 7.0 & --- & --- & 58.0 & --- & 1.0 & 0.5 & --- & --- & --- & 104.5 \\
\hline U3MI & 550 & na & 1.0 & --- & $-\ldots$ & $-\ldots$ & --- & --- & --- & 4.0 & --- & --- & 10.0 & 85.0 & --- & 0.5 & --- & --- & --- & 100.5 \\
\hline U3MI & 750 & na & 2.0 & ---- & 1.0 & --- & --- & --- & 3.0 & 3.0 & --- & -- & 12.0 & 79.0 & --- & 0.5 & --- & --- & --- & 100.5 \\
\hline U3MI & 810 & $\mathrm{ZC}$ & 6.0 & --- & 35.0 & --- & --- & --- & 13.0 & 1.0 & --- & $-\ldots$ & 33.0 & --- & - & 16.0 & 0.5 & -- & -- & 104.5 \\
\hline U3MI & 830 & $\mathrm{ZC}$ & 11.5 & --- & 16.0 & --- & --- & --- & 18.0 & 4.0 & --- & --- & 40.0 & --- & -- & 9.0 & --- & -- & --- & 98.5 \\
\hline U3MI & 870 & $\mathrm{ZC}$ & $\begin{array}{l}1.8 \\
\end{array}$ & -- & 67.5 & --- & --- & -- & 6.5 & 1.5 & 14.4 & 8.6 & $\begin{array}{l}--- \\
\end{array}$ & -- & -- & 0.5 & 0.9 & -- & -- & 101.8 \\
\hline U3MI & 920 & ZC & 0.6 & -- & 71.0 & 6.9 & --- & --- & 7.2 & 2.4 & 3.4 & 7.4 & --- & -- & -- & 2.1 & 0.2 & --- & --- & 101.2 \\
\hline U3MI & 990 & ZC & 1.3 & --- & 58.4 & 2.4 & --- & --- & 15.5 & 3.0 & 5.7 & 9.1 & --- & --- & --- & 0.2 & 0.1 & --- & --- & 95.7 \\
\hline U3MI & 1070 & ZC & 11.5 & --- & 25.0 & -- & --- & --- & 21.0 & 2.0 & --- & --- & 33.0 & --- & --- & 6.0 & 2.0 & --- & --- & 100.5 \\
\hline U3MI & 1080 & ZC & 15.0 & --- & 22.0 & --- & --- & --- & 11.0 & 1.0 & --- & --- & 37.0 & --- & --- & 6.0 & 2.0 & --- & --- & 94.0 \\
\hline U3MI & 1090 & ZC & 3.0 & --- & 34.0 & -- & -- & --- & 22.0 & 6.0 & --- & --- & 26.0 & -- & --- & 2.0 & 1.0 & -- & --- & 94.0 \\
\hline U3MI & 1100 & ZC & 7.0 & --- & 57.0 & --- & --- & --- & 10.0 & 3.0 & --- & --- & 21.0 & -- & -- & 0.5 & --- & -- & -- & 98.5 \\
\hline U3MI & 1120 & ZC & 1.2 & - & 55.1 & 3.4 & --- & --- & $\begin{array}{l}8.7 \\
\end{array}$ & 2.8 & 12.5 & 11.3 & |-- & --- & --. & 1.8 & --- & -- & - & 96.9 \\
\hline U3MI & 1310 & $\mathrm{ZC}$ & 0.5 & --- & 54.9 & $\begin{array}{l}7.7 \\
\end{array}$ & --- & --- & 7.0 & 5.7 & 7.6 & 13.5 & --- & --- & --- & 0.3 & --- & -- & -- & 97.3 \\
\hline U3MI & 1400 & $\mathrm{ZC}$ & 0.7 & --- & 58.0 & 16.4 & --- & --- & 4.8 & 3.7 & $\begin{array}{l}7.1 \\
\end{array}$ & 8.7 & --- & --- & --- & 1.1 & --- & --- & --- & 100.5 \\
\hline U3MI & 1450 & $\mathrm{ZC}$ & 0.6 & -- & 58.0 & 7.6 & --- & 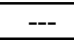 & 6.8 & 3.6 & 13.3 & 9.3 & -- & - & - & --- & --- & -- & --- & 99.2 \\
\hline U3MI & 1530 & ZC & 0.6 & --- & 55.2 & 16.6 & --- & --- & 6.5 & 5.0 & 7.0 & 7.9 & --- & --- & --- & --- & --- & --- & --- & 98.7 \\
\hline U3MI & 1600 & ZC & 1.1 & --.- & 78.8 & 5.9 & --- & --- & 0.8 & 5.0 & 6.9 & 2.9 & --- & --- & --- & --- & --- & --- & --- & 101.5 \\
\hline U3MI & 1630 & $\mathrm{ZC}$ & 8.0 & --- & 58.0 & -- & -- & --- & -- & 13.0 & -- & -- & 21.0 & --- & --- & 0.5 & --- & --- & --- & 100.5 \\
\hline U3MI & 1660 & $\mathrm{AR}$ & 39.0 & --- & 28.0 & --- & --- & $-\ldots$ & -- & 13.0 & --- & --- & 19.0 & --- & --- & 1.0 & -- & --- & -- & 100.0 \\
\hline U3MI & 1690 & $\mathrm{AR}$ & 49.0 & --- & --- & --- & --- & --- & --- & 19.0 & --- & --- & 32.0 & --- & --- & 1.0 & --- & --- & --- & 101.0 \\
\hline U3MI & 1710 & AR & 57.0 & --- & --- & --- & --- & -- & -- & 19.0 & --- & --- & 21.0 & --- & 1.0 & 1.0 & --- & --- & -- & 99.0 \\
\hline U3MI & 1720 & $\mathrm{AR}$ & 51.0 & -- & -- & -- & -- & -- & -- & 23.0 & -- & -- & 23.0 & -- & 1.0 & 1.0 & -- & -- & -- & 99.0 \\
\hline U3MI & 1730 & $\mathrm{AR}$ & 54.0 & --- & --- & --- & --- & --- & --- & 20.0 & --- & --- & 17.0 & --- & --- & -- & --- & 0.5 & --- & 91.5 \\
\hline U3MI & 1740 & AR & 68.0 & -- & --- & --- & --- & --. & -- & 19.0 & --- & --- & 15.0 & --- & --- & 0.5 & --- & --- & --- & 102.5 \\
\hline U3MI & 1750 & $A R$ & 80.0 & --- & --- & --- & --- & & --- & 11.0 & --- & --- & 3.0 & --- & --- & 2.0 & --- & --- & --- & 96.0 \\
\hline UE4AB & 1350 & na & --- & --- & 1.8 & --- & --- & --- & --- & 4.5 & 5.7 & 5.2 & -- & 79.5 & --- & 0.6 & --- & --- & --- & 97.3 \\
\hline UE4AB & 1400 & na & 18.4 & --- & 39.7 & --- & $-\ldots$ & --- & 5.0 & 6.5 & 7.7 & 20.8 & $-\ldots$ & --- & -- & 1.9 & 0.3 & -- & -- & 100.3 \\
\hline UE4AB & 1450 & na & 8.8 & --- & 16.2 & --- & --- & --- & -- & 0.5 & 9.9 & 17.7 & --- & 46.3 & -- & 0.5 & 0.3 & --- & --- & 100.2 \\
\hline UE4AB & 1550 & $\mathrm{ZC}$ & 3.0 & --- & 52.0 & --- & --- & --- & 11.6 & 5.9 & 8.4 & 13.0 & --- & --- & - & 2.3 & --- & -- & --- & 96.3 \\
\hline UE4AB & 1625 & $\mathrm{ZC}$ & 13.5 & -- & 71.8 & -- & -- & -- & 9.2 & 0.7 & 1.8 & 3.4 & -- & -- & --- & 0.5 & --- & -- & -- & 100.8 \\
\hline UE4AB & 1825 & ZC & 19.9 & --- & 41.7 & --- & --- & --- & 10.5 & 6.4 & 6.4 & 14.0 & -- & --- & --- & --- & 0.3 & -- & --- & 99.2 \\
\hline UE4AB & 1925 & ZC & 9.8 & --- & 50.6 & --- & --- & --- & 4.1 & 8.0 & 11.4 & 11.9 & --- & --- & --- & --- & 0.9 & --- & --- & 96.8 \\
\hline UE4AB & 2025 & ZC & 2.9 & --- & 70.0 & --- & ---- & 1.9 & 13.2 & 1.0 & 6.8 & 4.0 & --- & --- & --- & --- & --- & --- & --- & 99.8 \\
\hline UE4AB & 2125 & FS & 14.5 & --- & 35.4 & $\ldots$ & --- & 1.6 & 8.6 & 2.1 & 8.9 & 24.4 & --- & --- & --- & 2.6 & $\ldots$ & --- & --- & 98.1 \\
\hline UE4AB & 2250 & FS & 8.8 & --- & 47.1 & --- & --- & 1.1 & 8.4 & 0.7 & \begin{tabular}{|l|}
14.6 \\
\end{tabular} & 15.6 & --- & --- & --- & 2.6 & --- & --- & --- & 99.0 \\
\hline UE4AB & 2350 & FS & 6.2 & --- & 25.8 & --- & --- & 2.4 & 4.4 & 9.3 & \begin{tabular}{|l|}
15.5 \\
\end{tabular} & 27.8 & --- & --- & --. & 3.6 & --- & --- & -- & 94.9 \\
\hline UE4AB & 2450 & FS & 19.2 & --- & 19.6 & --- & --- & 1.1 & 1.1 & 14.4 & \begin{tabular}{|l|}
16.7 \\
\end{tabular} & 20.4 & --- & --- & -- & 2.7 & --- & --- & --- & 95.2 \\
\hline UE4AB & 2510 & FS & 111.6 & --- & 15.4 & -- & --- & 2.8 & 2.5 & 9.3 & 24.5 & 27.4 & --- & --- & -- & 4.2 & --- & -- & -- & 97.8 \\
\hline UE4AL & 1435 & na & 2.1 & --- & 56.6 & --- & --- & 1.2 & 5.6 & 4.7 & 10.8 & 14.6 & --- & --- & --- & 1.1 & 0.1 & --- & --- & 96.8 \\
\hline UE4AL & 1560 & ZC & 3.9 & --- & 58.4 & --- & --- & --- & 4.1 & 3.6 & \begin{tabular}{|l|}
6.2 \\
\end{tabular} & 17.3 & --- & --- & --- & 3.0 & 0.3 & 2.6 & --- & 99.4 \\
\hline
\end{tabular}




\begin{tabular}{|c|c|c|c|c|c|c|c|c|c|c|c|c|c|c|c|c|c|c|c|c|}
\hline \multirow[b]{2}{*}{ Drill Hole } & \multirow{2}{*}{$\begin{array}{c}\text { Sample } \\
\text { Depth (ft) }\end{array}$} & \multirow{2}{*}{$\begin{array}{c}\text { Mineralogic } \\
\text { Zone }^{1} \\
\end{array}$} & \multicolumn{17}{|c|}{ Mineral Abundance (\%) } & \multirow{2}{*}{$\begin{array}{c}\begin{array}{c}\text { Total } \\
(\%)\end{array} \\
\end{array}$} \\
\hline & & & SM & KA & $\mathrm{ZC}$ & ZM & ZA & $\mathbf{C R}$ & OP & QZ & $\mathrm{KF}$ & $\mathbf{P L}$ & FE & GL & HM & BT & $\mathrm{HN}$ & CC & Other & \\
\hline UE4AL & 1560 & $\mathrm{ZC}$ & 3.9 & --- & 58.4 & --- & --- & --- & 4.1 & 3.6 & 6.2 & 17.3 & --- & --- & --- & 3.0 & 0.3 & 2.6 & --- & 99.4 \\
\hline UE4AL & 1600 & $\mathrm{ZC}$ & 4.4 & --- & 54.1 & --- & --- & --- & 6.2 & 5.4 & 11.4 & 14.6 & - & --- & 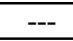 & 2.0 & 0.1 & --- & --- & 98.2 \\
\hline UE4AL & 1635 & $\mathrm{ZC}$ & 27.0 & --- & 34.0 & - & --- & - & 0.8 & 1.0 & 3.3 & 4.3 & $-\ldots$ & - & --- & 0.1 & 0.1 & 21.1 & - & 91.7 \\
\hline UE4AL & 1660 & $\mathrm{ZC}$ & 5.7 & --- & 69.1 & --- & --- & --- & 6.3 & 2.9 & 7.1 & 6.5 & - & --- & - & 0.7 & --- & --- & - & 98.3 \\
\hline UE7AX & 554 & na & 0.1 & --- & 39.1 & --- & -- & 0.2 & 38.4 & 6.9 & 4.1 & 9.5 & --- & --- & --- & 2.1 & 0.3 & 1.6 & --- & 102.3 \\
\hline UE7AX & 590.4 & na & 22.2 & --- & 37.0 & -- & --- & -- & 4.1 & 4.9 & 7.3 & 23.6 & -- & --- & -- & 5.3 & 0.3 & -- & --- & 104.7 \\
\hline UE7AX & 634.3 & na & --- & -- & --- & --- & -- & --- & --- & --- & --- & --- & --- & 100.0 & --- & -- & --- & --- & --- & 100.0 \\
\hline UE7AX & 658.2 & na & 10.3 & --- & 41.5 & --- & --- & 0.6 & 0.6 & 1.6 & 6.0 & 25.9 & --- & 8.6 & --- & 3.6 & 2.9 & --- & --- & 101.6 \\
\hline UE7AX & 706.1 & na & 1.9 & --- & 9.4 & $-\ldots$ & --- & 0.3 & 5.4 & 2.4 & 5.4 & 17.2 & $-\ldots$ & 58.9 & --- & 3.3 & 0.8 & --- & --- & 105.0 \\
\hline UE7AX & 729.8 & na & 5.5 & --- & 0.1 & --- & --- & -- & 5.5 & 8.1 & 5.8 & 11.2 & --- & 62.5 & --- & 1.9 & 0.8 & --- & --- & 101.4 \\
\hline UE7AX & 764.1 & na & 1.8 & --- & 0.4 & --- & --- & --- & 3.5 & --- & 11.6 & 15.7 & -- & 68.9 & -- & 1.0 & -- & --- & --- & 102.9 \\
\hline UE7AX & 789.5 & $\mathrm{ZC}$ & 0.2 & --- & 55.5 & --- & --- & --- & 14.2 & 4.2 & 11.4 & 12.2 & --- & --- & --- & 1.7 & --- & --- & --- & 99.3 \\
\hline UE7AX & 888.5 & $\mathrm{ZC}$ & 0.3 & -- & 56.4 & 13.8 & -- & --- & 11.7 & 2.1 & 4.7 & 7.0 & --- & --- & --- & 1.1 & -- & -- & -- & 97.1 \\
\hline UE7AX & 955.3 & $\mathrm{ZC}$ & 27.4 & --- & 43.1 & 2.8 & --- & -- & 10.7 & 0.9 & 5.3 & 9.7 & -- & -- & $-\cdots$ & 1.2 & --- & $-\ldots$ & -- & 101.0 \\
\hline UE7AX & 1011.1 & $\mathrm{ZC}$ & 2.6 & -- & 53.7 & 3.4 & --- & 0.8 & 20.0 & 3.7 & 9.3 & 6.7 & --- & --- & --- & 1.8 & --- & --- & --- & 102.1 \\
\hline UE7AX & 1066.8 & $\mathrm{ZC}$ & 7.4 & --- & 38.4 & -- & --- & 0.4 & 28.8 & 6.5 & 10.4 & 3.9 & --- & --- & --. & 3.7 & -.- & --. & -.- & 99.5 \\
\hline UE7AX & 1124.7 & $\mathrm{ZC}$ & 1.0 & --- & 47.3 & 2.9 & --- & 1.4 & 16.1 & 1.3 & 16.5 & 11.4 & --- & --- & --- & 1.0 & --- & --- & --- & 99.1 \\
\hline UE7AX & 1209.7 & FS & 0.3 & --- & 37.5 & -- & --- & 1.2 & 8.2 & 3.0 & 17.0 & 23.6 & --- & --- & --- & 6.0 & --- & --- & --- & 97.0 \\
\hline UE7AX & 1259.8 & FS & 1.2 & --- & 13.9 & --- & --- & 2.2 & 10.9 & 16.1 & 28.1 & 21.3 & --- & --- & --- & 2.6 & 1.5 & --- & --- & 97.7 \\
\hline UE7AX & 1291.3 & FS & 13.1 & -- & 46.8 & --- & -- & 1.0 & 7.0 & 0.6 & 8.0 & 23.3 & --- & --- & --- & 2.5 & --- & --- & --- & 102.3 \\
\hline UE7AX & 1320 & FS & 7.2 & -- & 38.9 & --- & -- & 0.9 & 8.1 & 8.0 & 15.7 & 19.7 & -- & --- & -- & 2.7 & --- & --- & -- & 101.3 \\
\hline UE7AX & 1339 & FS & 7.3 & -- & 71.9 & -- & -- & 2.5 & 6.8 & 1.9 & 6.2 & 7.2 & -- & --- & -- & -- & --- & -- & -- & 103.8 \\
\hline UE7BC & 907.2 & $\mathrm{ZC}$ & 0.4 & --- & 57.4 & --- & --- & 2.4 & 21.0 & 1.9 & 4.3 & 11.8 & --- & --- & --- & 0.6 & 0.3 & --- & --- & 100.1 \\
\hline UE7BC & 907.2 & $\mathrm{ZC}$ & 1.1 & -- & 51.2 & --- & --- & 2.5 & 26.8 & 1.5 & 7.1 & 10.9 & --- & --- & --- & 0.6 & 0.3 & --- & --- & 101.9 \\
\hline UE7BC & 907.2 & ZC & 1.1 & --- & 73.7 & --- & --- & 2.4 & 20.0 & 0.2 & 1.1 & 2.9 & --- & --- & $-\ldots$ & -- & 0.5 & --- & --- & 101.9 \\
\hline UE7BC & 937.3 & $\mathrm{ZC}$ & 2.4 & --- & 70.5 & --- & --- & 0.3 & 11.2 & 0.1 & 4.5 & 11.7 & --- & --- & $-\ldots$ & 3.1 & 0.2 & --- & --- & 103.9 \\
\hline UE7BC & 1077 & $\mathrm{ZC}$ & 10.6 & --- & 56.8 & --- & --- & 0.1 & 1.2 & 1.0 & 5.2 & 19.8 & --- & --- & --- & 5.5 & 3.9 & --- & --- & 104.1 \\
\hline UE7BC & 1265 & $\mathrm{ZC}$ & 0.2 & -- & 64.3 & 16.0 & -- & 1.3 & 6.9 & 2.0 & 3.5 & 5.8 & --- & 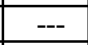 & --- & 0.4 & --- & --- & --- & 100.6 \\
\hline UE7BC & 1502 & $\mathrm{ZC}$ & --- & --- & 84.4 & 9.2 & --- & 0.6 & 6.8 & --- & 0.1 & 1.0 & --- & --- & --- & -- & --- & --- & --- & 102.1 \\
\hline UE7BC & 1728 & $\mathrm{ZC}$ & 0.3 & --- & 51.3 & -- & --- & 2.0 & 4.4 & 2.6 & 19.1 & 12.2 & --- & --- & --- & 5.8 & --- & --- & --- & 97.8 \\
\hline UE7BC & 1990 & FS & 15.9 & --- & --- & --- & --- & --- & --- & 26.2 & 31.7 & 18.4 & --- & --- & --- & 0.2 & --- & --- & --- & 93.4 \\
\hline UE7BC & 2201.5 & FS & 8.0 & --- & --- & --- & --- & --- & --- & 30.9 & 34.2 & 25.3 & --- & --- & 0.2 & 0.6 & --- & 0.9 & --- & 101.5 \\
\hline UE7BC & 2254.5 & FS & 13.9 & --- & 23.1 & 6.3 & 9.1 & --- & --- & 17.7 & 17.7 & 9.8 & --- & --- & --- & 2.8 & --- & 0.2 & --- & 100.6 \\
\hline UE7BC & 2377 & FS & 11.3 & --- & 37.7 & 1.4 & 2.7 & --- & --- & 12.8 & 13.8 & 14.4 & --- & --- & $-\ldots$ & 3.8 & --- & -- & --- & 97.9 \\
\hline UE7BC & 2554.1 & FS & 14.4 & -- & 23.7 & 2.9 & 6.7 & --- & --- & 18.4 & 20.2 & 9.7 & $-\ldots$ & --- & --- & 3.9 & $-\ldots$ & --- & --- & 99.8 \\
\hline UE7BC & 2687.1 & $\mathrm{AR}$ & 59.9 & 0.9 & --- & --- & -- & --- & --- & 25.0 & 12.5 & 1.7 & --- & --- & 1.4 & 1.6 & --- & --- & --- & 103.1 \\
\hline UE7F & 870.6 & na & --- & --- & --- & --- & --- & 1.7 & --- & 1.4 & 9.7 & 22.6 & --- & 61.9 & --- & 4.6 & --- & --- & --- & 101.9 \\
\hline UE7F & $\begin{array}{l}913.9 \\
\end{array}$ & na & --- & -- & --- & - & -- & 19.6 & --- & 10.3 & 36.7 & 30.4 & -- & --- & -- & 2.9 & --- & $-\cdots$ & -- & 99.9 \\
\hline UE7F & 1260.6 & $\mathrm{ZC}$ & 17.5 & --- & 33.1 & --- & --- & 1.1 & 14.1 & 4.9 & 7.0 & 14.2 & --- & --- & --- & 1.9 & 0.5 & 4.8 & --- & 99.2 \\
\hline UE7F & 1388.5 & ZC & 2.2 & --- & 66.7 & --- & --- & 0.6 & 14.3 & 1.7 & 6.8 & 7.8 & --- & --- & --- & 1.4 & 0.1 & $\ldots$ & --- & 101.5 \\
\hline UE7F & 1572.2 & $\mathrm{ZC}$ & 0.2 & --- & 60.8 & --- & --- & 1.8 & 17.7 & 3.5 & 4.2 & 9.7 & --- & --- & --- & 0.7 & 0.4 & --- & --- & 99.0 \\
\hline UE7F & 1749.1 & ZC & 1.3 & --- & 61.8 & --- & --- & 1.2 & 3.8 & 5.8 & 9.1 & 15.9 & --- & --- & --- & 1.7 & 1.1 & --- & --- & 101.7 \\
\hline UE7F & 1870 & $\mathrm{ZC}$ & 0.8 & --- & 49.8 & -- & --- & 4.4 & 12.0 & 1.4 & 18.9 & 10.0 & --- & -- & $-\ldots$ & 0.6 & --- & --- & --- & 97.9 \\
\hline UE7F & 1979.2 & $\mathrm{ZC}$ & 1.8 & --- & \begin{tabular}{|l|}
39.3 \\
\end{tabular} & 7.5 & --- & 2.2 & 6.5 & 7.3 & 18.6 & \begin{tabular}{|l|l}
11.4 \\
\end{tabular} & --- & --- & --- & 2.1 & --- & --- & --- & 96.8 \\
\hline
\end{tabular}




\begin{tabular}{|c|c|c|c|c|c|c|c|c|c|c|c|c|c|c|c|c|c|c|c|c|}
\hline \multirow[b]{2}{*}{ Drill Hole } & \multirow{2}{*}{$\begin{array}{c}\text { Sample } \\
\text { Depth (ft) }\end{array}$} & \multirow{2}{*}{$\begin{array}{c}\text { Mineralogic } \\
\text { Zone }^{1}\end{array}$} & \multicolumn{17}{|c|}{ Mineral Abundance (\%) } & \multirow{2}{*}{$\begin{array}{c}\text { Total } \\
(\%)\end{array}$} \\
\hline & & & SM & KA & $\mathrm{ZC}$ & ZM & ZA & CR & OP & $\mathbf{Q Z}$ & KF & $\mathrm{PL}$ & FE & GL & HM & BT & $\mathrm{HN}$ & CC & Other & \\
\hline \begin{tabular}{|l|} 
UE7F \\
\end{tabular} & 2063 & ZC & 11.6 & --- & 47.8 & 4.4 & --- & 0.6 & 4.0 & 9.9 & 13.3 & 10.7 & --- & --- & --- & --- & +-- & --- & --- & 102.4 \\
\hline UE7F & 2161 & FS & 2.9 & --- & 34.9 & --- & --- & --- & 1.0 & 15.9 & 19.9 & 17.2 & --- & --- & --- & 3.9 & --- & --- & --- & 95.8 \\
\hline UE7F & 2232.5 & FS & 19.6 & --- & 46.4 & --- & --- & 4.5 & 11.0 & 8.6 & 7.7 & 4.1 & --- & --- & --- & --- & --- & --- & --- & 101.8 \\
\hline UE7F & 2346.2 & FS & 2.0 & --- & 44.5 & --- & --- & --- & 1.7 & 11.9 & 20.4 & 10.1 & --- & --- & --- & 3.6 & --- & --- & --- & 94.3 \\
\hline UE7F & 2429 & FS & 7.5 & --- & --- & --- & 19.6 & --- & --- & 29.1 & 17.5 & 17.6 & --- & --- & --- & 3.3 & --- & --- & --- & 94.6 \\
\hline UE7F & 2520.4 & FS & 36.8 & --- & 22.8 & --- & --- & 0.2 & 1.4 & 7.0 & 8.8 & 25.7 & --- & --- & --- & 2.7 & --- & --- & --- & 105.4 \\
\hline UE7F & 2561.8 & FS & 4.2 & --- & 55.4 & --- & 2.6 & --- & 1.4 & 8.8 & 14.3 & 11.2 & --- & --- & --- & 3.8 & -- & --- & --- & 101.8 \\
\hline UE7F & 2654 & FS & 8.9 & --- & 43.5 & --- & 0.5 & --- & --- & 20.8 & 13.7 & 12.7 & --- & --- & --- & 2.8 & --- & --- & --- & 102.8 \\
\hline UE7F & 2752.8 & AR & 68.6 & 3.7 & --- & --- & --- & --- & --- & 10.4 & 10.3 & 4.1 & --- & --- & 1.0 & 1.5 & --- & --- & --- & 99.6 \\
\hline UE7F & 2793.1 & AR & 79.2 & --- & --- & --- & --- & --- & --- & 15.7 & 6.7 & 2.0 & --- & --- & --- & --- & --- & --- & --- & 103.6 \\
\hline UE7f & 2822.3 & na & --- & --- & --- & --- & --- & --- & --- & 15.8 & --- & --- & --- & --- & --- & --- & --- & 66.7 & Dolomite 22.1 & 104.6 \\
\hline UE8C & 755 & na & 45.3 & 4.0 & 0.4 & --- & --- & 1.2 & --- & 0.9 & 8.5 & 9.8 & --- & 31.5 & --- & 0.5 & --- & --- & \begin{tabular}{|c|}
-- \\
\end{tabular} & 102.1 \\
\hline UE8C & 795 & na & 1.8 & --- & 2.9 & --- & --- & 0.4 & --- & 16.7 & 31.5 & 28.6 & --- & --- & --- & 2.9 & 0.2 & --- & Tridymite 11.2 & 96.2 \\
\hline UE8C & 840 & na & 0.7 & --- & 0.6 & --- & --- & -- & --- & 0.3 & 6.3 & 24.6 & --- & 56.7 & 0.1 & 7.0 & 2.0 & --- & -- & 98.3 \\
\hline UE8C & 880 & ZC & 3.2 & 0.8 & 54.9 & $\begin{array}{l}-- \\
\end{array}$ & --- & --- & 1.7 & 4.2 & 9.2 & 17.3 & --- & --- & --- & 6.0 & 0.9 & --- & --- & 98.2 \\
\hline UE8C & 1160 & ZC & 1.0 & --- & 71.1 & --- & --- & --- & 6.2 & 3.9 & 4.5 & 11.4 & --- & --- & --- & 2.0 & 0.3 & --- & --- & 100.5 \\
\hline UE8C & 1240 & ZC & 1.1 & --- & 67.8 & --- & --- & -- & 12.8 & 4.0 & 3.9 & 8.9 & --- & --- & --- & 1.6 & -- & --- & --- & 100.0 \\
\hline UE8C & 1260 & FS & 0.2 & --- & 37.0 & --- & --- & 1.0 & 9.5 & 12.9 & 10.9 & 18.0 & --- & --- & --- & 3.5 & 0.5 & --- & --- & 93.5 \\
\hline UE8C & 1310 & FS & 28.0 & --- & 36.7 & --- & --- & 0.4 & 10.8 & 1.2 & 7.6 & 14.7 & --- & --- & --- & 1.0 & 0.3 & --- & --- & 100.7 \\
\hline UE9CP & 1240 & $Z C$ & 0.9 & --- & 67.4 & 1.0 & --- & 1.0 & 10.7 & 5.9 & 7.3 & 6.9 & --- & --- & --- & 1.2 & --- & --- & --- & 102.4 \\
\hline UE9CP & 1300 & $Z C$ & 24.9 & --- & 0.5 & --- & --- & 0.6 & --- & 2.6 & 7.4 & 26.5 & --- & 33.8 & 0.4 & 3.4 & 2.1 & --- & --- & 102.5 \\
\hline UE9CP & 1380 & ZC & 1.8 & --- & 71.1 & --- & --- & 2.0 & 13.8 & 2.1 & 5.9 & 4.2 & --- & --- & --- & 1.3 & --- & --- & --- & 102.2 \\
\hline UE9CP & 1440 & ZC & 3.3 & --- & 58.3 & --- & --- & 2.8 & 17.5 & 0.7 & 9.8 & 9.9 & --- & --- & --- & 2.5 & --- & --- & --- & 104.7 \\
\hline UE9CP & 1540 & FS & 1.4 & --- & 36.7 & --- & --- & 2.4 & 12.2 & 6.0 & 17.6 & 21.0 & --- & --- & --- & 3.7 & 3.7 & --- & --- & 104.6 \\
\hline UE9CP & 1620 & FS & 13.3 & --- & 37.4 & --- & --- & 1.0 & 2.9 & 1.7 & 11.2 & 29.9 & --- & --- & --- & 2.8 & --- & --- & --- & 100.2 \\
\hline UE9CP & 1680 & FS & 11.0 & --- & 30.4 & 2.9 & --- & 2.7 & 8.5 & 2.4 & 15.4 & 24.3 & --- & --- & --- & 4.3 & --- & --- & --- & 101.9 \\
\hline UE9CP & 1740 & FS & 9.3 & --- & 45.5 & 1.5 & --- & 2.4 & 9.0 & 2.3 & 14.3 & 14.9 & --- & --- & --- & 2.3 & --- & --- & --- & 101.4 \\
\hline U10as & 1080 & na & 10.6 & --- & --- & --- & --- & --- & --- & 0.9 & 1.8 & 2.6 & --- & 82.0 & --- & --- & --- & --- & --- & 97.9 \\
\hline U10as & 1130 & na & --- & --- & --- & --- & --- & --- & 2.5 & 5.2 & 5.3 & 5.4 & --- & 80.7 & --- & 0.7 & --- & --- & --- & 99.8 \\
\hline UE10BD & 1360 & na & 1.0 & --- & --- & --- & --- & --- & --- & 10.8 & 15.7 & 28.0 & --- & 35.2 & --- & 5.7 & 2.3 & --- & --- & 98.7 \\
\hline UE10BD & 1480 & na & 5.9 & --- & --- & --- & --- & --- & --- & 1.1 & 12.3 & 23.1 & --- & 51.1 & --- & 4.6 & 1.0 & --- & --- & 99.1 \\
\hline UE10BD & 1530 & na & 3.0 & --- & --- & --- & --- & --- & ---- & 12.2 & 15.7 & 32.5 & --- & 30.2 & 0.5 & 1.6 & 0.7 & --- & --- & 96.4 \\
\hline UE10BD & 1550 & na & 12.1 & 0.7 & --- & --- & --- & --- & --- & 6.1 & 10.3 & 13.2 & --- & 50.8 & 0.2 & 1.2 & 0.6 & --- & --- & 95.2 \\
\hline UE10BD & 1590 & AR & 61.8 & 5.2 & 8.5 & --- & --- & --- & --- & 3.5 & 7.6 & 12.1 & --- & --- & 0.4 & 3.3 & --- & --- & --- & 102.5 \\
\hline UE10BD & 1620 & AR & 65.1 & 4.2 & --- & --- & --- & --- & --- & 13.3 & 9.4 & 6.3 & --- & --- & 0.6 & 0.2 & -- & --- & --- & 99.0 \\
\hline UE10BD & 1650 & AR & 56.9 & 6.0 & --- & --- & --- & --- & --- & 20.7 & 6.5 & 5.1 & --- & --- & 0.8 & 1.3 & --- & 3.0 & --- & 100.2 \\
\hline UE10BF & 1470 & na & 20.7 & --- & 6.4 & --- & --- & --- & --- & 8.3 & 4.6 & 10.9 & --- & 48.4 & --- & 0.3 & 0.3 & --- & --- & 99.9 \\
\hline UE10BF & 1560 & na & 9.9 & --- & 13.3 & --- & --- & --- & 4.7 & 8.3 & 7.4 & 5.8 & --- & 49.3 & --- & --- & 0.9 & --- & --- & 99.6 \\
\hline UE10BF & 1630 & na & 16.2 & --- & 0.9 & --- & --- & 0.8 & --- & 4.9 & 2.8 & 10.0 & --- & 65.3 & --- & 0.4 & --- & --- & --- & 101.3 \\
\hline UE10BF & 1700 & na & 12.5 & --- & 1.8 & --- & --- & 0.5 & 0.1 & 1.3 & 3.6 & 3.7 & --- & 77.4 & --- & 0.3 & --- & --- & --- & 101.2 \\
\hline UE10BF & 1800 & na & 22.7 & --- & --- & --- & --- & 0.4 & --- & 2.2 & 6.3 & 17.1 & --- & 47.2 & --- & 1.4 & 0.4 & --- & --- & 97.7 \\
\hline UE10BF & 1850 & $Z C$ & 14.4 & --- & 56.0 & --- & --- & --- & 14.6 & 4.9 & 3.4 & 5.6 & --- & --- & --- & 1.1 & --- & --- & --- & 99.9 \\
\hline UE10BF & 1940 & $Z C$ & 7.3 & --- & 59.6 & --- & --- & 1.2 & 13.2 & 2.3 & 6.9 & 7.2 & --- & --- & --- & 0.5 & --- & --- & --- & 98.2 \\
\hline UE10BF & 2040 & $Z C$ & 21.7 & --- & 46.5 & --- & --- & 0.9 & 7.1 & 3.2 & 4.9 & 13.1 & --- & --- & --- & 2.1 & --- & --- & --- & 99.6 \\
\hline
\end{tabular}




\begin{tabular}{|c|c|c|c|c|c|c|c|c|c|c|c|c|c|c|c|c|c|c|c|c|}
\hline \multirow[b]{2}{*}{ Drill Hole } & \multirow{2}{*}{$\begin{array}{c}\text { Sample } \\
\text { Depth (ft) }\end{array}$} & \multirow{2}{*}{$\begin{array}{c}\text { Mineralogic } \\
\text { Zone }^{1}\end{array}$} & \multicolumn{17}{|c|}{ Mineral Abundance (\%) } & \multirow{2}{*}{$\begin{array}{c}\text { Total } \\
(\%)\end{array}$} \\
\hline & & & SM & KA & ZC & ZM & ZA & CR & OP & QZ & KF & PL & FE & GL & $\mathrm{HM}$ & BT & $\mathrm{HN}$ & CC & Other & \\
\hline UE10BF & 2120 & FS & 35.0 & $\overline{---}$ & 31.8 & $\overline{---}$ & $\begin{array}{l}-- \\
\end{array}$ & 2.1 & 13.8 & 2.0 & 6.1 & $\overline{11.5}$ & --- & +-- & --- & 1.5 & $\overline{---}$ & --- & --- & 103.8 \\
\hline UE10BF & 2160 & FS & 8.4 & --- & 34.9 & -- & --- & 1.9 & 7.3 & 0.9 & 9.1 & 32.7 & --- & 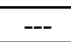 & --- & 1.7 & --- & --- & --- & 97.0 \\
\hline UE10BF & 2200 & FS & 16.7 & --- & 24.3 & -- & --- & 1.5 & 5.8 & 0.1 & 11.0 & 30.2 & -- & --- & --- & 3.4 & 1.4 & --- & --- & 94.4 \\
\hline UE15D & 923.3 & na & 4.8 & --- & --- & --- & --- & 10.0 & --- & 10.8 & 27.8 & 33.6 & -- & 11.9 & --- & --- & --- & --- & --- & 98.9 \\
\hline UE15D & 1010.3 & $Z C$ & 14.7 & --- & 59.9 & --- & --- & 0.5 & 8.1 & 1.5 & 7.1 & 8.6 & --- & --- & --- & --- & --- & --- & --- & 100.3 \\
\hline UE15D & 1083.7 & $Z C$ & 14.0 & --- & 63.3 & --- & --- & 0.7 & 8.7 & 0.8 & 2.9 & 6.7 & --- & --- & --- & 2.6 & --- & --- & --- & 99.8 \\
\hline UE15D & 1208 & ZC & 4.3 & --- & 50.0 & --- & --- & 1.0 & 6.3 & 2.6 & 8.5 & 19.2 & --- & --- & --- & 5.0 & 0.2 & --- & --- & 97.1 \\
\hline UE15D & 1285.3 & ZC & 38.1 & --- & 24.4 & --- & --- & 1.1 & 7.0 & 2.0 & 9.2 & 12.2 & --- & --- & --- & 2.2 & --- & --- & --- & 96.3 \\
\hline UE15D & 1357.8 & ZC & 6.6 & --- & 54.6 & --- & --- & 1.8 & 19.7 & 0.1 & 9.0 & 8.3 & --- & --- & --- & 2.0 & --- & --- & --- & 102.1 \\
\hline UE15D & 1446.3 & FS & 15.6 & -- & 30.5 & -- & --- & 2.2 & 17.7 & 1.6 & 15.6 & 13.0 & --- & -- & --- & 0.4 & --- & --- & --- & 96.7 \\
\hline UE15D & 1520 & FS & 6.4 & --- & 29.8 & --- & --- & 0.8 & 4.2 & 6.3 & 15.5 & 24.7 & --- & --- & --- & 7.8 & --- & --- & --- & 95.4 \\
\hline UE15D & 1585.2 & FS & 5.9 & --- & 35.9 & 2.1 & --- & 0.8 & 5.6 & 5.6 & 18.9 & 19.1 & --- & --- & --- & 2.8 & --- & --- & --- & 96.8 \\
\hline UE15D & 1691.1 & FS & 5.6 & --- & 43.0 & --- & --- & 1.9 & 6.2 & 10.1 & 13.9 & 14.5 & --- & --- & --- & 1.7 & --- & --- & --- & 96.9 \\
\hline UE15D & 1771 & FS & 31.8 & --- & 18.7 & --- & --- & 0.2 & 2.7 & 8.4 & 13.9 & 17.8 & --- & --- & --- & 3.4 & --- & --- & --- & 96.9 \\
\hline
\end{tabular}

\section{Explanation}

1 = zone designation based primarily on mineralogic composition, but also considers sample lithology and stratigraphy. $---=$ not present or not analyzed

na $=$ not applicable;sample does not fall into any of the $3 \mathrm{TCU}$ mineralogic zone categories.

$\mathrm{SM}=$ smectite

$\mathrm{KA}=$ kaolinite

$Z C=$ clinoptilolite

$\mathrm{ZM}=$ mordenite

$\mathrm{ZA}=$ analcime

$\mathrm{CR}=$ cristobalite

$\mathrm{OP}=$ opal-CT

$\mathrm{QZ}=$ quartz

$\mathrm{KF}=$ potasium feldspar

$\mathrm{PL}=$ plagioclase

FE $=$ feldspar, undifferentiated

$\mathrm{GL}=$ glass

$\mathrm{HM}=$ hematite

$\mathrm{BT}=$ biotite

$\mathrm{HN}=$ hornblende

$\mathrm{CC}=$ calcite 
This page intentionally left blank. 


\section{Appendix B}

\section{Drill Hole Database}


Drill Hole Database for the Yucca Flat TCU Study

\begin{tabular}{|c|c|c|c|c|c|c|c|c|}
\hline \multirow{2}{*}{ Drill Hole } & \multicolumn{2}{|c|}{ Hole Coordinates } & \multirow{2}{*}{$\begin{array}{l}\text { Ground } \\
\text { Elevation } \\
\text { (m) }\end{array}$} & \multirow{2}{*}{$\begin{array}{l}\text { Total Depth } \\
\text { Elevation } \\
\text { (m) }\end{array}$} & \multicolumn{4}{|c|}{$\begin{array}{c}\text { Elevation of Top of Zone (m) } \\
\text { (See explanation at end) }\end{array}$} \\
\hline & $\begin{array}{l}\text { Easting (m) } \\
\text { UTM }\end{array}$ & $\begin{array}{l}\text { Northing (m) } \\
\text { UTM }\end{array}$ & & & ZC Zone & FS Zone & AR Zone & Pz \\
\hline Effinger 1 & 575415.5 & 4116089.0 & 1570.0 & 1515.1 & NDE & NDE & NDE & NDE \\
\hline ER 12-1 & 572411.2 & 4115494.3 & 1773.0 & 679.4 & $\mathrm{NP}$ & $\mathrm{NP}$ & $\mathrm{NP}$ & 1771.0 \\
\hline ER 12-2 & 577823.3 & 4114254.6 & 1434.2 & -663.7 & NP & 1297 & NP & 1248.3 \\
\hline ER 2-1 & 583334.6 & 4108977.9 & 1285.1 & 492.6 & 701.4 & NDE & $\mathrm{NDE}$ & NDE \\
\hline ER 3-1 & 594657.9 & 4097338.8 & 1343.6 & 488.0 & \multicolumn{3}{|c|}{ Faulted Out } & 1058.9 \\
\hline ER 3-2 & 585716.4 & 4099227.6 & 1221.6 & 307.2 & NDE & NDE & NDE & NDE \\
\hline ER 6-1 & 589632.4 & 4093417.4 & 1199.4 & 222.2 & 1048.2 & 767.2 & 672.7 & 661.4 \\
\hline ER 6-2 & 582235.1 & 4090744.0 & 1289.9 & 244.4 & NP & NP & NP & 1259.1 \\
\hline ER 7-1 & 589235.7 & 4103471.9 & 1294.4 & 532.4 & 1065.8 & 913.4 & NP & 779.3 \\
\hline ER 8-1 & 583738.4 & 4118738.4 & 1468.8 & 596.2 & NP & 1374.3 & $\mathrm{NP}$ & 1134.7 \\
\hline Stewart 1 & 591781.7 & 4125878.9 & 1412.0 & $?$ & NDE & NDE & NDE & NDE \\
\hline TG2 & 581946.7 & 4099728.7 & 1255.8 & 1227.7 & NP & NP & NP & 1233.8 \\
\hline TH 3-1 & 588752.0 & 4101333.8 & 1260.7 & 1062.5 & NDE & NDE & NDE & NDE \\
\hline TH 3-4 & 589970.9 & 4101338.1 & 1281.4 & 1204.0 & NDE & NDE & NDE & NDE \\
\hline TH 3-5 & 589359.3 & 4101945.4 & 1283.8 & 1130.2 & NDE & NDE & NDE & NDE \\
\hline TH 3-8 & 589363.6 & 4100726.5 & 1260.0 & 1104.3 & NDE & NDE & NDE & NDE \\
\hline TH 3-9 & 589941.5 & 4101033.3 & 1272.8 & 677.6 & 910.1 & $?$ & NP & 696.8 \\
\hline TH 3-E & 589361.5 & 4101336.0 & 1271.6 & 473.0 & 918.4 & $?$ & 573.6 & 552.6 \\
\hline TW3-7 & 585900.4 & 4102299.9 & 1239.3 & 546.8 & 733.3 & NDE & NDE & NDE \\
\hline TW6-B & 587779.9 & 4092814.8 & 1197.6 & 687.0 & 795.2 & NDE & NDE & NDE \\
\hline TW6-C & 588214.1 & 4086123.9 & 1195.1 & 676.7 & 1047.3 & 826.3 & 815.3 & 782.1 \\
\hline TW D & 582223.6 & 4103325.5 & 1265.5 & 671.2 & \multicolumn{2}{|c|}{806.8} & 762.6 & 738.5 \\
\hline U10af & 584112.9 & 4112078.6 & 1297.5 & 764.1 & NDE & NDE & $\mathrm{NDE}$ & $\mathrm{NDE}$ \\
\hline U10ah & 584012.0 & 4112435.7 & 1298.8 & 837.0 & NDE & NDE & NDE & NDE \\
\hline U10an & 585339.8 & 4113289.7 & 1313.1 & 832.7 & \multicolumn{2}{|c|}{901.6} & NDE & NDE \\
\hline U10ap\#3 & 585340.3 & 4113063.3 & 1312.5 & 855.3 & NDE & NDE & NDE & NDE \\
\hline U10aq & 585880.8 & 4113349.5 & 1323.4 & 987.6 & $\mathrm{NDE}$ & NDE & NDE & NDE \\
\hline U10aq\#1 & 585880.7 & 4113364.7 & 1323.7 & 824.8 & $\mathrm{NDE}$ & NDE & $\mathrm{NDE}$ & NDE \\
\hline U10as & 584266.0 & 4114406.4 & 1310.0 & 944.3 & $\mathrm{NP}$ & $\mathrm{NP}$ & 959.5 & 954.9 \\
\hline U10ax & 585846.1 & 4113081.8 & 1321.9 & 1017.1 & $\mathrm{NDE}$ & NDE & $\mathrm{NDE}$ & NDE \\
\hline U10b & 582824.6 & 4114419.6 & 1333.5 & 876.0 & $?$ & $?$ & $?$ & 1153.4 \\
\hline U10b\#1 & 582836.2 & 4114399.8 & 1333.2 & 1052.8 & $?$ & $?$ & $?$ & 1165.3 \\
\hline U10b\#2 & 582824.1 & 4114541.5 & 1334.4 & 912.9 & $?$ & $?$ & $?$ & 1126.5 \\
\hline U10b\#3 & 582832.2 & 4114419.6 & 1333.5 & 906.8 & $?$ & $?$ & $?$ & 1165.6 \\
\hline U10b\#4 & 582823.8 & 4114632.9 & 1334.7 & 908.0 & $?$ & $?$ & $?$ & 1120.7 \\
\hline U10b\#5 & 582823.1 & 4114845.9 & 1337.5 & 910.7 & $?$ & $?$ & $?$ & 1131.4 \\
\hline U10b\#6 & 582869.2 & 4115332.4 & 1345.4 & 1151.8 & $?$ & $?$ & NP & 1305.5 \\
\hline U10bc & 585711.8 & 4112251.0 & 1312.2 & 1020.5 & $?$ & $?$ & 1039.7 & 1035.1 \\
\hline U10be & 583957.8 & 4117105.2 & 1378.3 & 1149.7 & NDE & NDE & NDE & NDE \\
\hline U10bg & 585684.7 & 4112159.4 & 1310.0 & 1089.1 & NDE & NDE & NDE & NDE \\
\hline U10bh & 584467.4 & 4115187.2 & 1317.3 & 1019.9 & NDE & NDE & NDE & NDE \\
\hline U10c & 583885.5 & 4111680.8 & 1298.4 & 710.2 & NDE & NDE & NDE & NDE \\
\hline U10c\#1 & 583894.3 & 4111689.4 & 1298.4 & 366.4 & $?$ & $?$ & $?$ & 368.5 \\
\hline U10ca & 585732.5 & 4116508.7 & 1344.5 & 1079.0 & 1132.9 & 1110.4 & NDE & NDE \\
\hline U10cb & 585703.6 & 4116402.5 & 1342.3 & 1112.2 & 1143.9 & NDE & NDE & NDE \\
\hline U10cc & 585645.4 & 4116576.0 & 1345.1 & 1115.0 & 1161.0 & NDE & NDE & NDE \\
\hline U10d EX.-1 & 585193.3 & 4112751.9 & 1308.2 & 675.4 & $?$ & $?$ & NDE & NDE \\
\hline U10d EX.-2 & 585358.5 & 4113516.2 & 1314.6 & 868.7 & $?$ & $?$ & NDE & NDE \\
\hline U10dS & 585374.6 & 4113515.6 & 1314.3 & 858.9 & $?$ & $?$ & NDE & NDE \\
\hline U10dS\#1 & 585381.1 & 4113495.8 & 1314.3 & 688.5 & $?$ & $?$ & 776.0 & 756.2 \\
\hline U10e & 585240.7 & 4111837.9 & 1300.3 & 801.9 & 873.6 & NDE & $\mathrm{NDE}$ & NDE \\
\hline U10i & 584740.9 & 4115308.2 & 1321.3 & 789.4 & \multicolumn{2}{|c|}{992.1} & $\mathrm{NP}$ & 821.0 \\
\hline U10its1 & 584643.5 & 4117107.6 & 1367.3 & 666.3 & 983.0 & 873.5 & $?$ & 698.3 \\
\hline U10its3 & 584648.4 & 4115706.2 & 1326.8 & 668.4 & 827.0 & 761.4 & $?$ & 695.9 \\
\hline U10its4 & 583583.8 & 4115153.6 & 1312.2 & 792.5 & \multicolumn{2}{|c|}{869.9} & $?$ & 806.2 \\
\hline
\end{tabular}




\begin{tabular}{|c|c|c|c|c|c|c|c|c|}
\hline \multirow{2}{*}{ Drill Hole } & \multicolumn{2}{|c|}{ Hole Coordinates } & \multirow{2}{*}{$\begin{array}{l}\text { Ground } \\
\text { Elevation } \\
\text { (m) }\end{array}$} & \multirow{2}{*}{$\begin{array}{l}\text { Total Depth } \\
\text { Elevation } \\
\text { (m) }\end{array}$} & \multicolumn{4}{|c|}{$\begin{array}{c}\text { Elevation of Top of Zone ( } \mathbf{m} \text { ) } \\
\text { (See explanation at end) }\end{array}$} \\
\hline & $\begin{array}{l}\text { Easting (m) } \\
\text { UTM }\end{array}$ & $\begin{array}{l}\text { Northing (m) } \\
\text { UTM }\end{array}$ & & & ZC Zone & FS Zone & AR Zone & Pz \\
\hline U10its5 & 583973.1 & 4117105.2 & 1378.3 & 662.0 & 915.0 & 793.1 & $?$ & 667.0 \\
\hline U10k & 584138.6 & 4113363.8 & 1302.4 & 573.6 & $?$ & $?$ & $?$ & 587.3 \\
\hline U10L\#1 & 584922.2 & 4112268.9 & 1299.7 & 626.7 & \multicolumn{2}{|c|}{781.5} & $?$ & 692.8 \\
\hline U10n\#1 & 582823.5 & 4114708.8 & 1335.6 & 995.8 & $?$ & $?$ & $?$ & 1115.6 \\
\hline U10p & 584439.7 & 4114120.9 & 1308.2 & 846.4 & $?$ & $?$ & NP & 874.2 \\
\hline $\mathrm{U10q}$ & 584495.3 & 4111591.5 & 1291.4 & 779.4 & NDE & NDE & NDE & NDE \\
\hline U10t & 585514.3 & 4112021.4 & 1306.1 & 763.5 & \multicolumn{2}{|c|}{882.4} & $?$ & 800.1 \\
\hline U2am & 583146.4 & 4109545.1 & 1297.8 & 519.1 & NDE & NDE & NDE & NDE \\
\hline U2ar & 582841.8 & 4108821.2 & 1292.0 & 591.0 & NDE & NDE & $\mathrm{NDE}$ & NDE \\
\hline U2as & 583612.4 & 4108400.4 & 1285.6 & 767.5 & NDE & NDE & NDE & NDE \\
\hline U2at & 584072.4 & 4108017.4 & 1279.9 & 610.8 & $?$ & $?$ & NDE & NDE \\
\hline U2au & 583943.0 & 4108335.1 & 1282.9 & 854.7 & NDE & NDE & NDE & NDE \\
\hline U2av & 583141.4 & 4110977.3 & 1310.0 & 641.6 & \multicolumn{2}{|c|}{711.1} & NDE & NDE \\
\hline U2aw & 582749.4 & 4109787.5 & 1301.8 & 641.6 & NDE & NDE & NDE & NDE \\
\hline U2az\#1 & 583308.5 & 4107656.1 & 1277.7 & 723.0 & NDE & NDE & NDE & NDE \\
\hline U2br & 582871.9 & 4111349.3 & 1314.3 & 757.7 & NDE & NDE & NDE & NDE \\
\hline U2bs & 583637.1 & 4108733.2 & 1288.1 & 678.5 & 761.1 & NDE & NDE & NDE \\
\hline U2bt & 584281.2 & 4107458.4 & 1274.7 & 726.0 & 872.9 & $?$ & $\mathrm{NDE}$ & NDE \\
\hline U2bu & 584281.8 & 4107306.0 & 1273.8 & 709.9 & 874.5 & $?$ & NDE & NDE \\
\hline U2bz & 582786.8 & 4112149.3 & 1320.7 & 912.3 & NDE & NDE & NDE & NDE \\
\hline U2ca\#1 & 576302.0 & 4110495.6 & 1484.7 & 1035.7 & \multicolumn{2}{|c|}{1234.8} & 1068.6 & 1051.6 \\
\hline U2ce & 576803.5 & 4110954.7 & 1452.1 & 1081.7 & $?$ & $?$ & $?$ & 1107.0 \\
\hline U2cms & 577514.5 & 4108321.7 & 1396.9 & 916.8 & $?$ & $?$ & NDE & NDE \\
\hline U2cn & 577488.3 & 4108504.4 & 1398.7 & 926.9 & $\mathrm{NP}$ & $?$ & $\mathrm{NP}$ & 974.8 \\
\hline U2co & 577567.8 & 4107986.7 & 1390.5 & 1033.9 & NDE & NDE & NDE & $\mathrm{NDE}$ \\
\hline $\mathrm{U} 2 \mathrm{cp}$ & 577928.0 & 4107733.2 & 1374.6 & 993.6 & NDE & NDE & NDE & NDE \\
\hline U2ca & 578034.4 & 4107531.2 & 1371.3 & 929.3 & NDE & NDE & NDE & NDE \\
\hline U2cr & 577686.8 & 4110988.6 & 1403.3 & 986.6 & $\mathrm{NP}$ & $\mathrm{NP}$ & $?$ & 1004.3 \\
\hline U2cs & 577997.4 & 4108795.7 & 1379.5 & 922.3 & $\mathrm{NDE}$ & NDE & $\mathrm{NDE}$ & $\mathrm{NDE}$ \\
\hline U2ct & 578020.1 & 4108038.5 & 1374.3 & 917.1 & NDE & NDE & NDE & NDE \\
\hline U2cu & 577995.7 & 4109283.2 & 1379.5 & 917.8 & $\mathrm{NP}$ & NDE & NDE & NDE \\
\hline $\mathrm{U} 2 \mathrm{db}$ & 581142.3 & 4109532.9 & 1314.3 & 681.8 & NDE & NDE & NDE & NDE \\
\hline U2dd\#4 & 581724.6 & 4107886.1 & 1295.1 & 830.9 & \multicolumn{2}{|c|}{898.9} & $?$ & 863.2 \\
\hline U2df & 581049.8 & 4110534.8 & 1327.1 & 758.6 & NDE & NDE & NDE & NDE \\
\hline U2dg & 581455.7 & 4109386.8 & 1311.2 & 619.4 & NDE & NDE & NDE & NDE \\
\hline U2dj & 581421.4 & 4110587.6 & 1323.1 & 600.5 & NDE & NDE & NDE & NDE \\
\hline U2dq & 581995.4 & 4107468.9 & 1289.9 & 886.1 & NDE & NDE & NDE & NDE \\
\hline U2dr & 581339.6 & 4109927.3 & 1314.6 & 698.9 & NDE & NDE & NDE & NDE \\
\hline U2ds & 582207.9 & 4107804.9 & 1291.1 & 912.3 & NDE & NDE & NDE & NDE \\
\hline U2dt & 581536.4 & 4108015.8 & 1297.5 & 738.8 & \multicolumn{2}{|c|}{837.3} & $?$ & 791.6 \\
\hline U2eh & 581498.9 & 4111688.9 & 1331.4 & 645.6 & NDE & NDE & NDE & NDE \\
\hline U2ei & 582803.1 & 4111844.6 & 1318.9 & 678.8 & 771.1 & $?$ & NDE & NDE \\
\hline U2ek & 583360.8 & 4109241.1 & 1291.4 & 530.0 & 724.4 & $?$ & NDE & NDE \\
\hline U2eL & 583305.8 & 4108417.9 & 1286.3 & 554.7 & NDE & NDE & NDE & NDE \\
\hline U2en & 583164.3 & 4108798.6 & 1288.1 & 540.7 & 641.9 & NDE & NDE & NDE \\
\hline U2eq & 583107.3 & 4107930.8 & 1281.1 & 761.1 & NDE & NDE & NDE & NDE \\
\hline U2er & 582884.9 & 4112871.8 & 1323.4 & 988.2 & NDE & NDE & NDE & NDE \\
\hline U2es & 582514.7 & 4111538.8 & 1320.4 & 802.2 & NDE & NDE & NDE & NDE \\
\hline U2et & 583164.3 & 4113140.9 & 1320.4 & 893.7 & $?$ & $?$ & $?$ & 901.3 \\
\hline U2ev & 581342.7 & 4111306.2 & 1330.8 & 901.6 & NDE & NDE & NDE & NDE \\
\hline U2ew & 583899.5 & 4108548.3 & 1282.9 & 825.7 & NDE & NDE & NDE & NDE \\
\hline U2ex & 582414.2 & 4110651.7 & 1314.0 & 701.6 & 714.1 & NDE & NDE & NDE \\
\hline U2ey & 582370.7 & 4113503.8 & 1336.2 & 1057.7 & $\mathrm{NP}$ & $\mathrm{NP}$ & $\mathrm{NP}$ & 1063.1 \\
\hline U2fa & 581179.2 & 4110131.8 & 1317.3 & 585.8 & NDE & NDE & NDE & NDE \\
\hline $\mathrm{U} 2 \mathrm{fb}$ & 581380.5 & 4109135.2 & 1301.8 & 734.9 & NDE & NDE & NDE & NDE \\
\hline $\mathrm{U} 2 \mathrm{fd}$ & 580969.2 & 4109095.6 & 1306.7 & 841.6 & NDE & NDE & NDE & NDE \\
\hline U2fe & 580885.6 & 4111213.2 & 1335.9 & 886.4 & NDE & NDE & NDE & NDE \\
\hline
\end{tabular}




\begin{tabular}{|c|c|c|c|c|c|c|c|c|}
\hline \multirow{2}{*}{ Drill Hole } & \multicolumn{2}{|c|}{ Hole Coordinates } & \multirow{2}{*}{$\begin{array}{l}\text { Ground } \\
\text { Elevation } \\
\text { (m) }\end{array}$} & \multirow{2}{*}{$\begin{array}{l}\text { Total Depth } \\
\text { Elevation } \\
(\mathrm{m})\end{array}$} & \multicolumn{4}{|c|}{$\begin{array}{l}\text { Elevation of Top of Zone (m) } \\
\text { (See explanation at end) }\end{array}$} \\
\hline & $\begin{array}{l}\text { Easting (m) } \\
\text { UTM }\end{array}$ & $\begin{array}{l}\text { Northing (m) } \\
\text { UTM }\end{array}$ & & & ZC Zone & FS Zone & AR Zone & Pz \\
\hline U2ff & 580941.7 & 4108257.5 & 1303.0 & 937.3 & NDE & NDE & NDE & NDE \\
\hline U2gaS & 582496.2 & 4110907.7 & 1314.3 & 766.6 & NDE & NDE & NDE & NDE \\
\hline U2gb & 583468.5 & 4108952.0 & 1286.0 & 712.9 & NDE & NDE & NDE & NDE \\
\hline U2ge & 581823.7 & 4110806.9 & 1321.3 & 736.1 & NDE & $\mathrm{NDE}$ & $\mathrm{NDE}$ & $\mathrm{NDE}$ \\
\hline U2gf & 582426.6 & 4108875.2 & 1295.1 & 743.4 & NDE & NDE & NDE & NDE \\
\hline U2gg & 582867.3 & 4110921.5 & 1307.3 & 752.2 & NDE & NDE & NDE & NDE \\
\hline U2gh & 583945.3 & 4107566.6 & 1273.1 & 724.2 & 740.1 & $\mathrm{NDE}$ & NDE & $\mathrm{NDE}$ \\
\hline U2gh\#1 & 579178.6 & 4111359.5 & 1353.3 & 1309.1 & $\mathrm{NP}$ & $\mathrm{NP}$ & $\mathrm{NP}$ & 1309.4 \\
\hline U2gj & 582346.7 & 4110369.0 & 1311.6 & 740.1 & NDE & NDE & $\mathrm{NDE}$ & NDE \\
\hline U2n\#1 & 582063.1 & 4111546.4 & 1326.8 & 634.0 & NDE & NDE & NDE & NDE \\
\hline U2q & 584097.3 & 4107781.0 & 1278.6 & 864.1 & NDE & NDE & NDE & NDE \\
\hline U2r\#1 & 582651.3 & 4109086.3 & 1299.1 & 280.4 & $?$ & $?$ & $?$ & 282.0 \\
\hline $\mathrm{U} 2 \mathrm{t}$ & 583702.4 & 4107414.0 & 1278.6 & 582.2 & $\mathrm{NDE}$ & $\mathrm{NDE}$ & NDE & NDE \\
\hline U2v & 582934.5 & 4109148.2 & 1297.2 & 526.1 & NDE & NDE & NDE & $\mathrm{NDE}$ \\
\hline $\mathrm{U} 2 \mathrm{x}$ & 583723.5 & 4107906.2 & 1282.0 & 500.2 & NDE & NDE & NDE & NDE \\
\hline U2z\#1 & 583774.6 & 4108815.1 & 1288.7 & 249.0 & $?$ & $?$ & $?$ & 326.0 \\
\hline U2z\#2 & 582304.7 & 4110593.5 & 1315.5 & 410.3 & 605.3 & $?$ & $\mathrm{NP}$ & 437.4 \\
\hline $\mathrm{U} 2 \mathrm{z} \# 3$ & 581925.3 & 4110180.8 & 1315.2 & 354.5 & $?$ & $?$ & 384.1 & 372.2 \\
\hline U3an\#1 & 585597.8 & 4102278.1 & 1237.5 & 469.4 & 551.7 & NDE & $\mathrm{NDE}$ & NDE \\
\hline U3an\#3 & 585598.0 & 4102307.6 & 1237.8 & 154.2 & $?$ & $?$ & 261.6 & 253.3 \\
\hline U3cn\#1 & 586973.1 & 4101827.6 & 1241.8 & 491.9 & NDE & NDE & $\mathrm{NDE}$ & NDE \\
\hline U3cn\#5 & 586921.4 & 4101713.2 & 1222.9 & 299.3 & 832.8 & 600.0 & 476.1 & 363.0 \\
\hline U3cp & 587529.2 & 4102369.0 & 1253.6 & 799.5 & 887.9 & NDE & NDE & NDE \\
\hline U3cs & 587533.2 & 4101211.0 & 1239.0 & 698.0 & 903.7 & NDE & NDE & NDE \\
\hline U3daS & 587973.2 & 4101654.1 & 1249.1 & 794.9 & NDE & NDE & NDE & NDE \\
\hline U3daS4 & 587972.0 & 4101649.8 & 1249.1 & 775.4 & 886.4 & NDE & NDE & NDE \\
\hline U3dh & 586307.5 & 4103157.0 & 1250.3 & 742.8 & 841.9 & NDE & NDE & NDE \\
\hline U3dL & 586919.7 & 4102550.0 & 1248.8 & 878.4 & 910.4 & NDE & NDE & NDE \\
\hline U3do & 587526.4 & 4103161.2 & 1264.3 & 894.0 & 929.0 & NDE & NDE & $\mathrm{NDE}$ \\
\hline U3dq & 589071.4 & 4097072.1 & 1211.9 & 878.1 & NDE & NDE & NDE & NDE \\
\hline U3eh & 586950.1 & 4102397.4 & 1247.9 & 775.4 & NDE & NDE & NDE & NDE \\
\hline U3eh\#1 & 586942.4 & 4102413.8 & 1246.6 & 858.0 & 888.5 & NDE & NDE & NDE \\
\hline U3ei & 587740.4 & 4102979.2 & 1264.3 & 730.9 & 895.5 & NDE & NDE & NDE \\
\hline U3ek & 589650.4 & 4097074.5 & 1222.2 & 986.0 & NDE & NDE & NDE & NDE \\
\hline U3ev\#3S & 589957.0 & 4100975.7 & 1274.1 & 921.7 & NDE & NDE & NDE & NDE \\
\hline U3ev\#5 & 589934.9 & 4101194.8 & 1279.2 & 918.1 & 1072.0 & NDE & NDE & NDE \\
\hline U3evS & 589971.5 & 4101097.7 & 1276.8 & 941.5 & NDE & NDE & NDE & NDE \\
\hline U3fc & 588761.0 & 4098594.7 & 1222.2 & 815.3 & 835.2 & NDE & NDE & NDE \\
\hline U3ff & 590223.7 & 4098600.1 & 1253.9 & 970.5 & NDE & NDE & NDE & NDE \\
\hline U3fh & 588759.2 & 4099204.1 & 1230.8 & 886.4 & NDE & NDE & NDE & NDE \\
\hline U3fk & 589610.8 & 4099755.6 & 1253.0 & 841.6 & NDE & NDE & NDE & NDE \\
\hline $\mathrm{U} 3 \mathrm{fL}$ & 588756.0 & 4100118.3 & 1240.5 & 987.6 & NDE & NDE & NDE & NDE \\
\hline U3fq & 586672.9 & 4103158.2 & 1254.6 & 843.1 & 934.5 & NDE & NDE & NDE \\
\hline U3fw & 589379.2 & 4096098.1 & 1215.2 & 962.3 & NDE & NDE & NDE & NDE \\
\hline U3fx & 588937.8 & 4100423.6 & 1248.8 & 995.8 & NDE & NDE & NDE & NDE \\
\hline U3gg & 584786.6 & 4102389.5 & 1243.3 & 557.5 & 802.8 & NDE & NDE & NDE \\
\hline U3gj & 590292.7 & 4096467.3 & 1234.1 & 980.2 & 1124.4 & 996.4 & NDE & NDE \\
\hline U3gk & 589468.3 & 4096859.9 & 1218.0 & 964.4 & NDE & NDE & NDE & NDE \\
\hline U3gm & 589385.4 & 4094330.7 & 1201.5 & 850.1 & 997.3 & NDE & NDE & NDE \\
\hline U3gr & 589681.3 & 4096495.6 & 1221.6 & 968.7 & 977.8 & NDE & NDE & NDE \\
\hline U3gs\#2 & 589692.6 & 4096748.5 & 1221.9 & 932.4 & 959.8 & NDE & NDE & NDE \\
\hline U3gx & 587893.6 & 4098393.6 & 1215.2 & 808.3 & 819.0 & NDE & NDE & NDE \\
\hline U3gz & 589063.9 & 4099205.2 & 1232.9 & 810.8 & 870.2 & NDE & NDE & NDE \\
\hline U3hg\#1 & 588296.9 & 4096353.3 & 1207.3 & 759.3 & 783.6 & NDE & NDE & NDE \\
\hline U3jq & 588748.3 & 4102312.3 & 1272.5 & 692.5 & 946.4 & 754.4 & NDE & NDE \\
\hline U3jq\#1 & 588763.5 & 4102312.4 & 1272.5 & 594.7 & 946.4 & 752.6 & 632.4 & 597.4 \\
\hline U3ko & 586492.8 & 4102456.7 & 1242.7 & 815.9 & 907.4 & NDE & NDE & NDE \\
\hline
\end{tabular}




\begin{tabular}{|c|c|c|c|c|c|c|c|c|}
\hline \multirow{2}{*}{ Drill Hole } & \multicolumn{2}{|c|}{ Hole Coordinates } & \multirow{2}{*}{$\begin{array}{l}\text { Ground } \\
\text { Elevation } \\
\text { (m) }\end{array}$} & \multirow{2}{*}{$\begin{array}{l}\text { Total Depth } \\
\text { Elevation } \\
\text { (m) }\end{array}$} & \multicolumn{4}{|c|}{$\begin{array}{c}\text { Elevation of Top of Zone ( } \mathbf{m} \text { ) } \\
\text { (See explanation at end) }\end{array}$} \\
\hline & $\begin{array}{l}\text { Easting (m) } \\
\text { UTM }\end{array}$ & $\begin{array}{l}\text { Northing (m) } \\
\text { UTM }\end{array}$ & & & ZC Zone & FS Zone & AR Zone & Pz \\
\hline U3ks & 588249.7 & 4096764.5 & 1208.8 & 716.6 & 827.8 & NDE & NDE & NDE \\
\hline U3kv & 588070.5 & 4095727.8 & 1205.8 & 718.1 & NDE & $\mathrm{NDE}$ & NDE & NDE \\
\hline U3kx & 587228.1 & 4101331.8 & 1237.5 & 795.5 & 829.1 & NDE & NDE & NDE \\
\hline U3kz & 584480.9 & 4102754.4 & 1245.1 & 559.3 & 726.9 & NDE & NDE & NDE \\
\hline U3La & 584856.9 & 4102755.7 & 1244.5 & 558.7 & 833.0 & $\mathrm{NDE}$ & $\mathrm{NDE}$ & NDE \\
\hline U3Lh & 588081.6 & 4096992.5 & 1204.6 & 777.8 & 810.0 & NDE & NDE & NDE \\
\hline U3Lr & 584881.0 & 4101536.9 & 1238.1 & 780.9 & 785.5 & $\mathrm{NDE}$ & NDE & NDE \\
\hline U3Lu & 588585.9 & 4094733.5 & 1202.7 & 867.8 & NDE & NDE & NDE & NDE \\
\hline U3Lw & 588279.4 & 4096993.2 & 1209.1 & 782.4 & 846.4 & NDE & $\mathrm{NDE}$ & NDE \\
\hline U3Ly & 588278.6 & 4097206.5 & 1209.8 & 767.8 & 825.7 & NDE & NDE & NDE \\
\hline U3me & 584882.9 & 4101003.7 & 1235.0 & 549.2 & 775.7 & NDE & NDE & NDE \\
\hline U3mf & 584879.9 & 4101857.2 & 1239.6 & 569.1 & 803.5 & NDE & NDE & NDE \\
\hline $\mathrm{U} 3 \mathrm{mh}$ & 590070.5 & 4098751.6 & 1247.2 & 716.3 & 1098.8 & 805.2 & 746.0 & 726.9 \\
\hline U3mi & 589703.7 & 4095776.2 & 1220.4 & 673.6 & 981.1 & $\mathrm{NP}$ & 719.0 & 678.2 \\
\hline U3mk & 589600.3 & 4102650.5 & 1297.5 & 916.5 & 1015.9 & NDE & NDE & NDE \\
\hline $\mathrm{U} 3 \mathrm{~mL}$ & 590030.3 & 4097441.5 & 1234.7 & 838.5 & 992.4 & NDE & NDE & NDE \\
\hline U3mL\#1 & 590022.7 & 4097441.1 & 1234.4 & & 992.1 & NDE & $\mathrm{NDE}$ & NDE \\
\hline U3mt & 584878.9 & 4102131.1 & 1239.6 & 767.2 & 821.4 & NDE & $\mathrm{NDE}$ & NDE \\
\hline $\mathrm{U} 3 \mathrm{mu}$ & 589601.7 & 4102254.9 & 1294.2 & 837.0 & 955.2 & 896.4 & $\mathrm{NDE}$ & $\mathrm{NDE}$ \\
\hline $\mathrm{U} 4 \mathrm{a}$ & 584191.2 & 4106990.0 & 1270.7 & 310.0 & 840.9 & 606.2 & 361.2 & 338.0 \\
\hline$U 4 a b$ & 580723.2 & 4105392.3 & 1290.5 & 991.8 & NDE & NDE & NDE & NDE \\
\hline U4ac & 580586.3 & 4105315.7 & 1292.7 & 1048.2 & NDE & NDE & NDE & NDE \\
\hline U4ad & 580553.9 & 4105879.3 & 1296.0 & 982.1 & $?$ & $?$ & 1004.6 & 998.9 \\
\hline U4af & 580782.4 & 4105880.1 & 1291.7 & 986.9 & $\mathrm{NP}$ & $\mathrm{NP}$ & 1019.2 & 1014.7 \\
\hline U4ah & 581625.2 & 4104511.5 & 1274.7 & 924.2 & 953.0 & NDE & $\mathrm{NDE}$ & NDE \\
\hline U4ai & 582669.3 & 4104386.0 & 1262.5 & 773.3 & NDE & NDE & NDE & NDE \\
\hline U4aj & 582197.5 & 4106418.0 & 1280.2 & 792.5 & NDE & NDE & NDE & NDE \\
\hline U4ak & 582801.8 & 4103540.8 & 1259.1 & 762.3 & 780.0 & NDE & NDE & NDE \\
\hline U4am & 581415.9 & 4104857.8 & 1276.8 & 941.5 & NDE & $\mathrm{NDE}$ & $\mathrm{NDE}$ & NDE \\
\hline U4an & 582279.0 & 4106647.2 & 1281.4 & 793.7 & 887.9 & NDE & NDE & $\mathrm{NDE}$ \\
\hline U4ap & 581075.7 & 4107221.9 & 1294.8 & 952.8 & \multicolumn{2}{|c|}{993.0} & $?$ & 973.8 \\
\hline U4ar & 582551.9 & 4104688.1 & 1264.6 & 761.7 & NDE & NDE & NDE & NDE \\
\hline U4as & 578065.7 & 4107226.6 & 1367.9 & 926.0 & NDE & NDE & NDE & NDE \\
\hline U4at & 578112.3 & 4106967.7 & 1365.2 & 901.6 & NDE & NDE & NDE & NDE \\
\hline U4au & 582788.9 & 4104607.0 & 1263.4 & 730.0 & NDE & NDE & NDE & NDE \\
\hline U4av & 582680.3 & 4105777.1 & 1273.1 & 755.0 & 862.9 & NDE & NDE & NDE \\
\hline U4b & 584359.9 & 4105698.3 & 1263.4 & 763.5 & NDE & NDE & NDE & NDE \\
\hline U4c & 584133.8 & 4106044.2 & 1267.4 & 581.6 & 822.4 & NDE & NDE & NDE \\
\hline U4d & 584162.2 & 4106653.8 & 1270.1 & 583.7 & 767.2 & NDE & NDE & NDE \\
\hline U4d\#1 & 584173.7 & 4106663.3 & 1270.1 & 497.1 & 829.7 & 575.2 & NDE & NDE \\
\hline $\mathrm{U} 4 \mathrm{e}$ & 583856.7 & 4106866.3 & 1271.9 & 249.9 & 723.3 & 541.4 & 310.9 & 276.8 \\
\hline U4e\#1 & 583719.6 & 4106865.5 & 1273.5 & 285.9 & 729.4 & 496.3 & 308.8 & 289.0 \\
\hline $\mathrm{U} 4 \mathrm{f}$ & 584199.1 & 4104825.6 & 1258.5 & 545.3 & 795.2 & NDE & NDE & NDE \\
\hline U4g & 584315.2 & 4106380.1 & 1265.5 & 521.8 & 793.1 & 534.0 & NDE & NDE \\
\hline U4h & 584007.6 & 4107293.2 & 1272.5 & 541.0 & 818.4 & 573.0 & NDE & NDE \\
\hline U4i & 583012.5 & 4104284.5 & 1260.7 & 590.1 & 763.2 & NDE & NDE & NDE \\
\hline $\mathrm{U} 4 \mathrm{j}$ & 584319.2 & 4105222.4 & 1260.0 & 574.2 & 850.1 & NDE & NDE & NDE \\
\hline $\mathrm{U} 4 \mathrm{~L}$ & 583986.1 & 4106455.1 & 1267.7 & 557.2 & 786.1 & NDE & NDE & NDE \\
\hline $\mathrm{U} 4 \mathrm{~m}$ & 584164.7 & 4104805.3 & 1258.5 & 759.0 & NDE & NDE & NDE & NDE \\
\hline $\mathrm{U} 4 \mathrm{n}$ & 584184.9 & 4104862.7 & 1258.8 & 588.3 & NDE & NDE & NDE & NDE \\
\hline $\mathrm{U} 40$ & 584466.4 & 4106806.9 & 1267.7 & 688.5 & 920.2 & NDE & NDE & NDE \\
\hline U4p & 584501.0 & 4107089.2 & 1269.8 & 705.9 & 925.4 & NDE & NDE & NDE \\
\hline $\mathrm{U} 4 \mathrm{q}$ & 584589.2 & 4106533.4 & 1263.7 & 626.7 & 920.8 & NDE & NDE & NDE \\
\hline $\mathrm{U} 4 \mathrm{r}$ & 584186.3 & 4104542.7 & 1255.5 & 569.7 & 741.9 & NDE & NDE & NDE \\
\hline $\mathrm{U} 4 \mathrm{~s}$ & 583978.9 & 4104611.5 & 1257.3 & 647.7 & 662.9 & NDE & NDE & NDE \\
\hline U4t & 584590.3 & 4106233.2 & 1263.1 & 647.4 & 944.9 & NDE & NDE & NDE \\
\hline U4t\#1 & 584578.1 & 4106233.2 & 1263.1 & 623.0 & 943.1 & NDE & NDE & NDE \\
\hline
\end{tabular}




\begin{tabular}{|c|c|c|c|c|c|c|c|c|}
\hline \multirow{2}{*}{ Drill Hole } & \multicolumn{2}{|c|}{ Hole Coordinates } & \multirow{2}{*}{$\begin{array}{l}\text { Ground } \\
\text { Elevation } \\
\text { (m) }\end{array}$} & \multirow{2}{*}{$\begin{array}{l}\text { Total Depth } \\
\text { Elevation } \\
(\mathrm{m})\end{array}$} & \multicolumn{4}{|c|}{$\begin{array}{l}\text { Elevation of Top of Zone ( } m \text { ) } \\
\text { (See explanation at end) }\end{array}$} \\
\hline & $\begin{array}{l}\text { Easting (m) } \\
\text { UTM }\end{array}$ & $\begin{array}{l}\text { Northing (m) } \\
\text { UTM }\end{array}$ & & & ZC Zone & FS Zone & AR Zone & $\mathbf{P z}$ \\
\hline $\mathrm{U} 4 \mathrm{u}$ & 584496.9 & 4104964.0 & 1255.8 & 585.2 & 862.6 & NDE & NDE & $\mathrm{NDE}$ \\
\hline U4u\#1 & 584488.3 & 4104968.9 & 1255.5 & 753.8 & 859.3 & NDE & NDE & $\mathrm{NDE}$ \\
\hline U6d & 588591.1 & 4093261.4 & 1198.5 & 802.2 & 866.5 & NDE & NDE & $\mathrm{NDE}$ \\
\hline U6e & 588587.3 & 4094337.0 & 1201.5 & 744.3 & 842.8 & NDE & NDE & $\mathrm{NDE}$ \\
\hline U6f & 588437.8 & 4093535.1 & 1199.4 & 803.1 & 836.7 & NDE & NDE & $\mathrm{NDE}$ \\
\hline $\mathrm{UTa}$ & 585989.0 & 4106999.7 & 1296.9 & 474.3 & 946.4 & $?$ & 496.5 & 481.3 \\
\hline U7aa & 589599.6 & 4102863.8 & 1300.6 & 713.8 & 1078.1 & 910.4 & $?$ & 854.0 \\
\hline U7ab & 588742.6 & 4103927.6 & 1295.7 & 776.6 & 1042.7 & 798.9 & NDE & $\mathrm{NDE}$ \\
\hline U7ac & 586062.8 & 4103430.4 & 1250.3 & 575.8 & 880.0 & 578.2 & $\mathrm{NDE}$ & $\mathrm{NDE}$ \\
\hline U7ad & 586482.8 & 4106603.4 & 1306.1 & 707.1 & 949.5 & 751.3 & NDE & $\mathrm{NDE}$ \\
\hline U7ad\#1 & 586470.1 & 4106595.2 & 1306.4 & 648.0 & 949.8 & 727.3 & NDE & $\mathrm{NDE}$ \\
\hline U7ae & 588267.5 & 4104733.2 & 1300.3 & 430.7 & 1016.8 & 745.5 & $?$ & 480.4 \\
\hline U7af & 586452.3 & 4105321.0 & 1282.3 & 676.4 & 956.2 & 747.4 & NDE & $\mathrm{NDE}$ \\
\hline U7ag & 586293.4 & 4107185.1 & 1306.4 & 704.4 & 1013.8 & 750.1 & NDE & $\mathrm{NDE}$ \\
\hline U7ah & 585659.5 & 4105623.0 & 1274.1 & 295.7 & 853.4 & 600.5 & 512.1 & 411.5 \\
\hline U7ai & 586217.1 & 4102791.3 & 1244.8 & 580.3 & 796.7 & NDE & $\mathrm{NDE}$ & NDE \\
\hline U7ajS & 585621.7 & 4106250.9 & 1281.7 & 583.7 & 877.8 & 655.3 & NDE & $\mathrm{NDE}$ \\
\hline U7ak & 585529.1 & 4106926.7 & 1285.0 & 599.2 & 840.0 & NDE & NDE & $\mathrm{NDE}$ \\
\hline $\mathrm{U} 7 \mathrm{aL}$ & 587129.7 & 4103312.2 & 1261.6 & 801.3 & 941.5 & 844.0 & NDE & $\mathrm{NDE}$ \\
\hline U7am & 586390.6 & 4105625.5 & 1286.0 & 661.1 & 959.8 & 697.7 & $\mathrm{NDE}$ & $\mathrm{NDE}$ \\
\hline U7an & 584996.1 & 4103457.1 & 1249.7 & 286.2 & 920.5 & 553.8 & NDE & $\mathrm{NDE}$ \\
\hline U7ao & 587154.1 & 4104957.8 & 1286.3 & 826.0 & 926.6 & 844.3 & NDE & $\mathrm{NDE}$ \\
\hline U7ap & 584882.1 & 4105559.3 & 1264.3 & 639.5 & 999.1 & 682.1 & NDE & NDE \\
\hline U7aq & 584449.2 & 4103089.5 & 1247.9 & 144.5 & 687.0 & 394.4 & $?$ & 162.8 \\
\hline U7at & 587512.7 & 4107061.7 & 1336.2 & 876.0 & 1153.4 & 970.5 & NP & 909.2 \\
\hline U7au & 584324.0 & 4103942.3 & 1253.0 & 509.3 & 760.8 & NDE & NDE & NDE \\
\hline U7av & 584995.2 & 4103823.1 & 1252.4 & 661.7 & 943.1 & NDE & NDE & $\mathrm{NDE}$ \\
\hline U7aw & 585536.8 & 4105956.2 & $\begin{array}{l}1276.8 \\
\end{array}$ & 586.7 & 874.5 & NDE & NDE & $\mathrm{NDE}$ \\
\hline U7ax & 587818.3 & 4106819.0 & 1337.8 & 956.8 & 1151.8 & 1010.1 & NDE & $\mathrm{NDE}$ \\
\hline U7ay & 587120.0 & 4106085.2 & 1309.4 & 821.7 & 1029.0 & 858.3 & NDE & $\mathrm{NDE}$ \\
\hline U7b & 588133.7 & 4103772.8 & 1281.1 & 810.2 & 915.3 & NDE & NDE & $\mathrm{NDE}$ \\
\hline U7ba & 584900.2 & 4104756.4 & 1258.5 & 648.9 & 984.8 & 660.5 & NDE & $\mathrm{NDE}$ \\
\hline U7bc & 588431.6 & 4103893.3 & 1289.0 & 603.2 & 1031.4 & 798.3 & NDE & $\mathrm{NDE}$ \\
\hline U7bd & 588105.8 & 4104182.3 & 1287.5 & 677.9 & 953.7 & 799.8 & NDE & $\mathrm{NDE}$ \\
\hline U7be & 586148.0 & 4106325.6 & 1292.7 & 683.1 & 966.5 & 748.6 & NDE & $\mathrm{NDE}$ \\
\hline U7bf & 586112.8 & 4106629.9 & 1296.3 & 848.6 & 924.5 & NDE & NDE & $\mathrm{NDE}$ \\
\hline U7bg & 588499.2 & 4106431.3 & 1337.5 & 941.2 & 1169.8 & 1001.3 & NDE & NDE \\
\hline U7bh & 588352.5 & 4106546.6 & 1338.7 & 942.4 & 1181.7 & 986.6 & NDE & NDE \\
\hline U7bi & 588930.5 & 4105098.1 & 1318.0 & 860.8 & 1069.8 & 911.0 & NDE & $\mathrm{NDE}$ \\
\hline U7bk & 587665.5 & 4106940.0 & 1338.4 & 961.9 & 1135.4 & 998.5 & 968.4 & 960.1 \\
\hline U7bL & 587485.9 & 4106025.5 & 1315.8 & 764.1 & 1053.7 & 779.4 & NDE & NDE \\
\hline U7bm & 588957.4 & 4103409.7 & 1291.7 & 819.3 & 1047.9 & NDE & NDE & $\mathrm{NDE}$ \\
\hline U7bo & 586866.4 & 4106899.1 & 1319.2 & 709.6 & 1057.0 & 819.3 & NDE & $\mathrm{NDE}$ \\
\hline U7bp & 588298.9 & 4104471.2 & 1294.8 & 609.0 & 1032.7 & 683.7 & NDE & $\mathrm{NDE}$ \\
\hline U7br & 584883.3 & 4105223.8 & 1261.0 & 651.4 & 994.3 & 678.8 & NDE & $\mathrm{NDE}$ \\
\hline U7bs & 585994.1 & 4105624.1 & 1277.7 & 600.8 & 851.0 & NDE & NDE & NDE \\
\hline U7bs\#1 & 585979.2 & 4105623.5 & 1277.7 & 571.5 & 847.3 & NDE & NDE & NDE \\
\hline U7bu & 584808.8 & 4103174.3 & 1246.0 & 636.4 & 836.1 & NDE & NDE & $\mathrm{NDE}$ \\
\hline U7bv & 588717.2 & 4105097.4 & 1310.6 & 914.4 & 1106.4 & NDE & NDE & NDE \\
\hline U7bw & 588485.7 & 4103332.2 & 1282.0 & 672.4 & 900.7 & 776.0 & NDE & $\mathrm{NDE}$ \\
\hline U7by & 586783.0 & 4106602.0 & 1310.6 & 762.0 & 1053.1 & 853.4 & NDE & $\mathrm{NDE}$ \\
\hline U7bz & 586041.0 & 4105289.7 & 1272.8 & 575.5 & 877.8 & 673.9 & 631.2 & 614.2 \\
\hline U7c & 587219.5 & 4103769.6 & 1269.5 & 878.1 & 934.2 & NDE & $\mathrm{NDE}$ & $\mathrm{NDE}$ \\
\hline U7ca & 588835.0 & 4103653.4 & 1293.6 & 744.9 & 1065.0 & 813.5 & NDE & $\mathrm{NDE}$ \\
\hline U7cb & 588718.2 & 4104822.8 & 1306.7 & 742.8 & 1065.9 & 819.0 & NDE & $\mathrm{NDE}$ \\
\hline U7cc & 586783.5 & 4106358.6 & 1306.4 & 818.7 & 1061.0 & 843.1 & NDE & $\mathrm{NDE}$ \\
\hline U7cd & 584902.6 & 4104066.2 & 1254.3 & 759.0 & 937.3 & NDE & NDE & $\mathrm{NDE}$ \\
\hline
\end{tabular}




\begin{tabular}{|c|c|c|c|c|c|c|c|c|}
\hline \multirow{2}{*}{ Drill Hole } & \multicolumn{2}{|c|}{ Hole Coordinates } & \multirow{2}{*}{$\begin{array}{l}\text { Ground } \\
\text { Elevation } \\
\text { (m) }\end{array}$} & \multirow{2}{*}{$\begin{array}{l}\text { Total Depth } \\
\text { Elevation } \\
(\mathrm{m})\end{array}$} & \multicolumn{4}{|c|}{$\begin{array}{l}\text { Elevation of Top of Zone (m) } \\
\text { (See explanation at end) }\end{array}$} \\
\hline & $\begin{array}{l}\text { Easting (m) } \\
\text { UTM }\end{array}$ & $\begin{array}{l}\text { Northing (m) } \\
\text { UTM }\end{array}$ & & & ZC Zone & FS Zone & AR Zone & $\mathrm{Pz}$ \\
\hline U7cd\#1 & 584912.0 & 4104066.9 & 1253.9 & 735.8 & 940.3 & NDE & NDE & NDE \\
\hline U7e & 585905.5 & 4104740.1 & 1263.7 & 676.4 & 821.7 & $\mathrm{NDE}$ & NDE & NDE \\
\hline U7f & 585932.0 & 4105958.8 & 1284.1 & 708.1 & 872.6 & NDE & NDE & NDE \\
\hline U7g & 587402.4 & 4103770.0 & 1271.6 & 800.7 & 921.1 & NDE & NDE & NDE \\
\hline U7h & 586153.0 & 4103765.9 & 1255.2 & 785.5 & 916.8 & $\mathrm{NDE}$ & $\mathrm{NDE}$ & NDE \\
\hline U7i & 587211.8 & 4105291.7 & 1294.2 & 715.1 & 1012.2 & NDE & NDE & NDE \\
\hline$U 7 \mathrm{~J}$ & 587087.7 & 4106511.4 & 1318.6 & 741.0 & 1044.2 & $\mathrm{NDE}$ & NDE & NDE \\
\hline U7k & 585760.6 & 4102698.0 & 1240.5 & 661.4 & NDE & NDE & NDE & NDE \\
\hline $\mathrm{UTm}$ & 589306.9 & 4103776.9 & 1304.5 & 786.4 & 1036.3 & NDE & NDE & NDE \\
\hline U7n & 588521.3 & 4106212.0 & 1333.2 & 755.6 & 1144.2 & 808.9 & 804.1 & 790.7 \\
\hline U7n\#1 & 588506.3 & 4106226.9 & 1333.2 & 750.1 & 1138.7 & 808.9 & $?$ & 785.2 \\
\hline U7o & 585686.1 & 4106568.0 & 1287.2 & 708.1 & 863.5 & NDE & NDE & NDE \\
\hline U7p & 587644.8 & 4104166.9 & 1281.7 & 702.6 & 940.3 & NDE & NDE & NDE \\
\hline U7s & 588741.0 & 4104384.4 & 1300.9 & 721.8 & 1011.3 & 743.1 & NDE & NDE \\
\hline U7t & 588372.4 & 4105144.6 & 1307.9 & 728.8 & 1018.3 & $?$ & NDE & NDE \\
\hline U7u & 585690.3 & 4105287.9 & 1269.2 & 583.4 & 799.8 & NDE & NDE & NDE \\
\hline U7v & 586510.9 & 4105991.6 & 1296.3 & 717.2 & 942.7 & 735.5 & NDE & NDE \\
\hline $\mathrm{U} 7 \mathrm{w}$ & 589308.0 & 4103471.9 & 1297.2 & 763.8 & 1035.1 & 844.6 & NDE & NDE \\
\hline U7x & 588155.2 & 4106240.9 & 1328.9 & 795.5 & 1106.4 & NDE & NDE & NDE \\
\hline U7y & 588441.0 & 4102969.4 & 1276.2 & 697.1 & 940.9 & 718.4 & $\mathrm{NDE}$ & NDE \\
\hline U7z & 585633.1 & 4104205.6 & 1252.1 & 671.2 & NDE & NDE & NDE & NDE \\
\hline U7z\#1 & 588669.7 & 4104205.3 & 1252.1 & 601.4 & 709.9 & NDE & NDE & NDE \\
\hline U8a & 580092.4 & 4114838.7 & 1406.7 & 1047.0 & 1048.6 & $?$ & NDE & NDE \\
\hline U8a\#1 & 580095.1 & 4114866.2 & 1406.0 & 1028.7 & $?$ & $?$ & $?$ & 1047.9 \\
\hline U8a\#10 & 580032.1 & 4114232.7 & 1392.6 & 808.0 & $?$ & $?$ & $\mathrm{NP}$ & 950.7 \\
\hline U8a\#11 & 580016.8 & 4114077.9 & 1391.1 & 798.3 & $?$ & $?$ & $?$ & 943.1 \\
\hline U8a\#12 & 579960.0 & 4113506.0 & 1383.5 & 875.1 & \multicolumn{2}{|c|}{1051.3} & 1009.2 & 1000.4 \\
\hline U8a\#3 & 580089.2 & 4114802.5 & 1405.1 & 1002.2 & $?$ & $?$ & $?$ & 1024.1 \\
\hline U8a\#4 & 580091.0 & 4114823.8 & 1406.3 & 819.6 & 1061.9 & $\mathrm{NP}$ & NP & 1036.3 \\
\hline U8a\#5 & 580080.4 & 4114717.7 & 1403.3 & 819.6 & $?$ & $?$ & 1092.4 & 1016.2 \\
\hline U8a\#6 & 580074.2 & 4114656.8 & 1401.5 & 881.2 & 1115.0 & $\mathrm{NP}$ & NP & 1018.5 \\
\hline U8a\#7 & 580068.0 & 4114596.4 & 1399.9 & 871.1 & $?$ & $?$ & $?$ & 1011.0 \\
\hline U8a\#8 & 580062.1 & 4114535.7 & 1398.4 & 868.1 & $?$ & $?$ & 1143.6 & 1011.3 \\
\hline U8a\#9 & 580043.9 & 4114353.7 & 1394.5 & 827.5 & $?$ & $?$ & $?$ & 973.5 \\
\hline U8b & 580631.1 & 4114259.2 & 1379.8 & 1065.9 & NDE & NDE & NDE & NDE \\
\hline U8d & 580000.0 & 4114254.6 & 1394.2 & 1094.8 & NDE & NDE & NDE & NDE \\
\hline U8e & 581040.9 & 4114029.4 & 1367.9 & 758.3 & $\mathrm{NP}$ & 810.1 & NDE & NDE \\
\hline U8e\#1 & 581132.2 & 4114037.3 & 1367.9 & 573.9 & $\mathrm{NP}$ & 839.1 & 669.0 & 649.5 \\
\hline U8j & 580872.2 & 4115022.2 & 1388.7 & 779.1 & 1179.0 & 1065.6 & 812.0 & 788.7 \\
\hline U8k & 581247.4 & 4114732.8 & 1373.4 & 1006.1 & NP & 1058.0 & NDE & NDE \\
\hline U8L & 581288.0 & 4115239.7 & 1383.2 & 1150.0 & $\mathrm{NP}$ & $?$ & NDE & NDE \\
\hline U8m & 580980.9 & 4114443.6 & 1373.7 & 855.6 & $\mathrm{NP}$ & 969.0 & NDE & NDE \\
\hline U8n & 580630.2 & 4114503.3 & 1384.4 & 807.4 & 1064.1 & 1015.3 & NDE & NDE \\
\hline U9s\#25 & 585184.8 & 4110466.5 & 1286.9 & 782.7 & \multicolumn{2}{|c|}{851.0} & $\mathrm{NDE}$ & NDE \\
\hline U9t\#28 & 585305.4 & 4110832.5 & 1291.1 & 896.4 & NDE & NDE & NDE & NDE \\
\hline U9u\#29 & 585426.9 & 4110954.9 & 1293.3 & 947.3 & NDE & NDE & NDE & NDE \\
\hline U9w\#21 & 585673.8 & 4109980.9 & 1290.5 & 971.4 & 1046.7 & $?$ & NDE & NDE \\
\hline U9x\#20 & 585796.7 & 4109859.2 & 1293.0 & 1012.5 & $?$ & $?$ & NDE & NDE \\
\hline U9aa\#27 & 586159.1 & 4110713.7 & 1306.4 & 1098.5 & $?$ & $?$ & $?$ & 1117.4 \\
\hline U9ad & 584346.5 & 4110554.9 & 1290.5 & 737.9 & $?$ & $?$ & NDE & NDE \\
\hline U9ae & 585378.4 & 4107419.6 & 1284.1 & 880.9 & NDE & $\mathrm{NDE}$ & NDE & NDE \\
\hline U9aj & 586075.1 & 4108090.6 & 1301.2 & 1142.7 & NDE & NDE & NDE & NDE \\
\hline U9ao & 584451.8 & 4110875.3 & 1289.6 & 785.2 & NDE & NDE & NDE & NDE \\
\hline U9aw & 585382.0 & 4108118.9 & 1284.1 & 1048.8 & NDE & $\mathrm{NDE}$ & NDE & NDE \\
\hline U9ax & 584826.7 & 4108331.8 & 1274.7 & 947.0 & NDE & NDE & NDE & NDE \\
\hline U9ay & 585607.3 & 4109127.1 & 1286.6 & 1009.5 & NDE & NDE & NDE & NDE \\
\hline U9az & 585062.4 & 4110618.4 & 1287.8 & 815.3 & NDE & NDE & NDE & NDE \\
\hline
\end{tabular}




\begin{tabular}{|c|c|c|c|c|c|c|c|c|}
\hline \multirow{2}{*}{ Drill Hole } & \multicolumn{2}{|c|}{ Hole Coordinates } & \multirow{2}{*}{$\begin{array}{l}\text { Ground } \\
\text { Elevation } \\
(\mathrm{m})\end{array}$} & \multirow{2}{*}{$\begin{array}{l}\text { Total Depth } \\
\text { Elevation } \\
\text { (m) }\end{array}$} & \multicolumn{4}{|c|}{$\begin{array}{c}\text { Elevation of Top of Zone (m) } \\
\text { (See explanation at end) }\end{array}$} \\
\hline & $\begin{array}{c}\text { Easting (m) } \\
\text { UTM }\end{array}$ & $\begin{array}{c}\text { Northing (m) } \\
\text { UTM }\end{array}$ & & & ZC Zone & FS Zone & AR Zone & $\mathbf{P z}$ \\
\hline U9ba & 585599.6 & 4109517.2 & 1287.8 & 1098.8 & NDE & NDE & NDE & NDE \\
\hline U9bb & 585952.2 & 4109751.5 & 1296.6 & 1059.5 & NDE & NDE & NDE & NDE \\
\hline U9bd & 586581.0 & 4107728.5 & 1315.5 & 1126.5 & NDE & NDE & NDE & NDE \\
\hline U9be & 586292.5 & 4107438.3 & 1307.0 & 1072.3 & NDE & NDE & NDE & NDE \\
\hline U9bg & 586140.0 & 4107468.6 & 1303.3 & 1074.7 & NDE & NDE & NDE & NDE \\
\hline U9bh & 586639.5 & 4108317.1 & 1313.7 & 1009.8 & 1054.6 & NDE & NDE & NDE \\
\hline U9bi\#1 & 585749.2 & 4108469.4 & 1290.8 & 810.8 & NDE & NDE & NDE & NDE \\
\hline U9bi\#2 & 586296.7 & 4108498.2 & 1303.9 & 862.0 & NDE & NDE & NDE & NDE \\
\hline U9bj & 586535.7 & 4107606.8 & 1314.9 & 1078.7 & NDE & NDE & NDE & NDE \\
\hline U9bj\#1 & 586541.8 & 4107606.8 & 1314.9 & 1071.1 & $?$ & $?$ & NDE & NDE \\
\hline U9bk & 586490.4 & 4107916.2 & 1312.8 & 1160.4 & NDE & NDE & NDE & NDE \\
\hline U9bm & 586089.3 & 4108117.8 & 1301.2 & 1148.8 & NDE & NDE & NDE & NDE \\
\hline U9bn & 586381.0 & 4108261.4 & 1308.2 & 986.6 & $?$ & $?$ & NDE & NDE \\
\hline U9bo & 586777.9 & 4107958.1 & 1320.4 & 1129.9 & NDE & NDE & NDE & NDE \\
\hline U9bp & 585681.6 & 4107862.8 & 1299.7 & 1060.4 & NDE & NDE & NDE & NDE \\
\hline U9br & 586397.2 & 4108002.7 & 1310.0 & 1002.2 & NDE & NDE & NDE & NDE \\
\hline U9br1 & 586393.0 & 4108009.6 & 1310.0 & 1005.2 & \multicolumn{2}{|c|}{1009.8} & NDE & NDE \\
\hline U9br2 & 586654.8 & 4108218.3 & 1315.5 & 1010.1 & \multicolumn{2}{|c|}{1077.8} & NDE & NDE \\
\hline U9bs & 585774.5 & 4107421.3 & 1293.9 & 954.0 & NDE & NDE & NDE & NDE \\
\hline U9bt & 586061.3 & 4107680.4 & 1301.8 & 1068.6 & NDE & NDE & NDE & NDE \\
\hline U9bu & 585209.9 & 4107663.1 & 1280.8 & 905.9 & NDE & NDE & NDE & NDE \\
\hline U9bx & 584631.5 & 4110187.5 & 1286.3 & 646.2 & NDE & NDE & NDE & NDE \\
\hline U9bz & 585247.8 & 4109887.4 & 1283.8 & 1032.4 & NDE & NDE & NDE & NDE \\
\hline U9ca\#1 & 584175.8 & 4111285.7 & 1293.6 & 315.2 & 708.4 & $?$ & 403.0 & 354.5 \\
\hline U9cb & 584997.6 & 4111471.1 & 1293.9 & 735.5 & \multicolumn{2}{|c|}{815.4} & NDE & NDE \\
\hline U9ce & 584146.8 & 4111026.9 & 1293.0 & 608.7 & 640.7 & $?$ & NDE & NDE \\
\hline U9cg & 584466.2 & 4111195.3 & 1290.2 & 954.9 & $?$ & $?$ & NDE & NDE \\
\hline U9ch & 585529.7 & 4107725.1 & 1288.1 & 867.5 & NDE & NDE & NDE & NDE \\
\hline U9ci & 585965.5 & 4108579.0 & 1295.1 & 1036.0 & NDE & NDE & NDE & NDE \\
\hline U9ci\#1 & 585973.4 & 4108578.4 & 1295.1 & 917.4 & 961.3 & $?$ & NDE & NDE \\
\hline U9ck & 585209.3 & 4107845.9 & 1280.8 & 944.9 & NDE & NDE & NDE & NDE \\
\hline U9cL & 586976.9 & 4107775.9 & 1327.1 & 972.0 & 1068.0 & $?$ & NDE & NDE \\
\hline U9cm & 587164.9 & 4108127.5 & 1329.8 & 974.7 & 1034.1 & $?$ & NDE & NDE \\
\hline U9cn & 587372.7 & 4107792.5 & 1338.4 & 1002.5 & \multicolumn{2}{|c|}{1035.1} & NDE & NDE \\
\hline U9co & 584517.5 & 4109610.9 & 1283.2 & 551.7 & 589.8 & $?$ & NDE & NDE \\
\hline U9cq & 587191.3 & 4107487.2 & 1332.6 & 997.0 & 1103.1 & $?$ & NDE & NDE \\
\hline U9cr & 585828.6 & 4109371.7 & 1293.0 & 924.2 & 987.9 & $?$ & NDE & NDE \\
\hline U9cs & 586856.1 & 4107486.0 & 1322.5 & 956.2 & 1117.1 & $?$ & NDE & NDE \\
\hline U9ct & 583707.4 & 4110339.7 & 1300.0 & 781.2 & NDE & NDE & NDE & NDE \\
\hline U9cv & 586059.0 & 4108854.5 & 1295.7 & 838.5 & 1026.0 & $?$ & NDE & NDE \\
\hline U9cw & 587572.0 & 4107445.6 & 1342.6 & 1129.3 & 1146.0 & $?$ & NDE & NDE \\
\hline U9d & 584494.0 & 4108643.9 & 1280.5 & 940.6 & NDE & NDE & NDE & NDE \\
\hline U9x & 585930.8 & 4108049.5 & 1297.8 & 1034.2 & NDE & NDE & NDE & NDE \\
\hline U9z\#21 & 586039.8 & 4109982.2 & 1300.0 & 1088.7 & NP & NP & NP & 1093.0 \\
\hline U9z\#24 & 586038.5 & 4110344.2 & 1301.8 & 1095.1 & NP & $\mathrm{NP}$ & NP & 1152.8 \\
\hline U9z\#27 & 586037.2 & 4110713.2 & 1303.0 & 1039.1 & $\mathrm{NP}$ & NP & NP & 1090.0 \\
\hline UE 10aa & 585438.2 & 4116409.5 & 1341.4 & 917.8 & NP & 1042.1 & $?$ & 996.4 \\
\hline UE 10bd & 585425.2 & 4112295.7 & 1307.3 & 790.7 & NP & NP & 824.2 & 802.9 \\
\hline UE 10bf & 584509.7 & 4116147.2 & 1337.2 & 646.5 & 780.9 & 700.0 & NP & 659.3 \\
\hline UE 10bg & 585730.5 & 4112159.6 & 1310.3 & 1009.5 & $?$ & $?$ & $?$ & 1017.4 \\
\hline UE 10j & 581526.1 & 4115644.0 & 1394.2 & 668.7 & NP & 1278.0 & $\mathrm{NP}$ & 1078.1 \\
\hline UE 15d & 585061.4 & 4118300.8 & 1398.0 & -431.1 & 1155.4 & 971.3 & $\mathrm{NP}$ & 857.0 \\
\hline UE 15j & 592299.1 & 4117406.6 & 1452.0 & 1071.6 & $?$ & $?$ & $?$ & 1420.0 \\
\hline UE 1a & 578394.4 & 4100386.7 & 1311.6 & 1019.9 & $\mathrm{NP}$ & $\mathrm{NP}$ & $\mathrm{NP}$ & 1037.2 \\
\hline UE 1b & 579003.8 & 4100388.8 & 1302.4 & 920.2 & $?$ & $?$ & NP & 1070.5 \\
\hline UE 1c & 580222.7 & 4100393.1 & 1282.0 & 709.0 & $?$ & $?$ & 746.2 & 742.0 \\
\hline UE 1d & 578713.6 & 4100601.1 & 1309.4 & 1048.2 & $?$ & $?$ & 1080.8 & 1074.7 \\
\hline
\end{tabular}




\begin{tabular}{|c|c|c|c|c|c|c|c|c|}
\hline \multirow{2}{*}{ Drill Hole } & \multicolumn{2}{|c|}{ Hole Coordinates } & \multirow{2}{*}{$\begin{array}{l}\text { Ground } \\
\text { Elevation } \\
\text { (m) }\end{array}$} & \multirow{2}{*}{$\begin{array}{c}\text { Total Depth } \\
\text { Elevation } \\
\text { (m) }\end{array}$} & \multicolumn{4}{|c|}{$\begin{array}{c}\text { Elevation of Top of Zone (m) } \\
\text { (See explanation at end) }\end{array}$} \\
\hline & $\begin{array}{l}\text { Easting (m) } \\
\text { UTM }\end{array}$ & $\begin{array}{l}\text { Northing }(m) \\
\text { UTM }\end{array}$ & & & ZC Zone & FS Zone & AR Zone & $\mathbf{P z}$ \\
\hline UE 1e & 579491.9 & 4100238.2 & 1293.9 & 771.4 & \multicolumn{2}{|c|}{903.4} & 836.7 & 824.2 \\
\hline UE $1 f$ & 578813.6 & 4100148.0 & 1303.6 & 1089.4 & NP & NP & NP & 1132.9 \\
\hline UE 1g & 579276.5 & 4100846.9 & 1299.4 & 859.8 & $?$ & $?$ & NP & 880.3 \\
\hline UE 1h & 582983.3 & 4095222.4 & 1217.7 & 194.2 & NP & NP & $?$ & 699.5 \\
\hline UE 1j & 582445.3 & 4096591.8 & 1230.0 & 732.6 & $\mathrm{NP}$ & $\mathrm{NP}$ & $\mathrm{NP}$ & 781.8 \\
\hline UE 1L & 576566.4 & 4100380.3 & 1357.6 & -269.7 & $\mathrm{NP}$ & $\mathrm{NP}$ & $\mathrm{NP}$ & 1296.6 \\
\hline UE 1q & 583722.2 & 4101776.6 & 1244.2 & 501.4 & 695.6 & $?$ & 534.0 & 527.9 \\
\hline UE $1 r$ & 583673.7 & 4098227.3 & 1231.4 & -43.3 & 431.9 & $?$ & 118.9 & 116.4 \\
\hline UE 2a\#1 & 580864.0 & 4108806.6 & 1319.7 & 570.0 & NP & $\mathrm{NP}$ & 674.8 & 585.4 \\
\hline UE 2aa & 582406.5 & 4111980.3 & 1325.3 & 619.0 & 666.9 & $?$ & $?$ & 624.2 \\
\hline UE 2ab & 580336.6 & 4111363.6 & 1345.1 & 958.0 & $\mathrm{NP}$ & NP & NP & 982.1 \\
\hline UE 2ac & 580098.7 & 4109686.8 & 1325.9 & 1083.0 & NP & NP & NP & 1100.0 \\
\hline UE 2ad & 578667.3 & 4109529.4 & 1355.8 & 1091.8 & $\mathrm{NP}$ & NP & 1120.5 & 1117.7 \\
\hline UE 2ar Ins & 582830.9 & 4108810.5 & 1292.7 & 576.1 & NDE & NDE & NDE & NDE \\
\hline UE 2aw & 582743.3 & 4109793.9 & 1302.1 & 592.5 & 641.9 & $?$ & NDE & NDE \\
\hline UE 2ax & 581408.6 & 4112043.2 & 1340.5 & 450.5 & 625.0 & $?$ & $?$ & 480.4 \\
\hline UE 2ax\#2 & 581425.3 & 4111994.9 & 1339.9 & 593.1 & 627.0 & $?$ & NDE & NDE \\
\hline UE $2 b$ & 581137.3 & 4109484.7 & 1313.7 & 243.2 & $?$ & $?$ & 309.4 & 286.8 \\
\hline UE 2ce & 576803.8 & 4110772.2 & 1452.1 & 949.1 & \multicolumn{2}{|c|}{1158.0} & NP & 1115.0 \\
\hline UE 2co & 577575.5 & 4107971.5 & 1390.5 & 805.0 & $\mathrm{NP}$ & $\mathrm{NP}$ & 852.9 & 847.0 \\
\hline UE 2dj Ins & 581405.9 & 4110575.1 & 1323.1 & 606.9 & $\mathrm{NDE}$ & NDE & NDE & NDE \\
\hline UE 2dy & 581079.7 & 4107907.0 & 1299.4 & 731.8 & NP & $\mathrm{NP}$ & $?$ & 744.3 \\
\hline UE 2dz & 581580.9 & 4108898.2 & 1302.4 & 570.9 & $?$ & NDE & NDE & NDE \\
\hline UE 2en & 583118.6 & 4108798.4 & 1288.7 & 671.8 & $?$ & $?$ & NDE & NDE \\
\hline UE 2en\#1 & 583118.5 & 4108813.7 & 1288.1 & 526.1 & $?$ & $?$ & NDE & NDE \\
\hline UE 2ep & 582921.6 & 4108493.0 & 1288.1 & 465.1 & $?$ & $?$ & NDE & NDE \\
\hline UE 2eu & 580818.1 & 4112541.5 & 1353.6 & 509.3 & $?$ & $?$ & $?$ & 550.5 \\
\hline UE 2fa & 581148.4 & 4110132.3 & 1317.3 & 463.9 & NDE & NDE & $\mathrm{NDE}$ & NDE \\
\hline UE 2fa\#1 & 580978.1 & 4110131.1 & 1319.8 & 445.6 & $\mathrm{NP}$ & $\mathrm{NP}$ & 488.9 & 487.7 \\
\hline UE 2fb & 581365.3 & 4109112.2 & 1302.7 & 452.3 & \multicolumn{2}{|c|}{522.4} & NP & 510.8 \\
\hline UE 2s Inst & 577503.9 & 4108321.6 & 1396.9 & 796.4 & \multicolumn{2}{|c|}{890.9} & $?$ & 867.8 \\
\hline UE 3a & 589985.6 & 4097075.3 & 1229.9 & 709.9 & 906.8 & $?$ & NDE & NDE \\
\hline UE 3c & 586569.3 & 4098115.0 & 1215.5 & 131.7 & 630.9 & $?$ & NDE & NDE \\
\hline UE 3e & 584475.5 & 4102814.7 & 1244.5 & 479.5 & 730.9 & $?$ & NDE & NDE \\
\hline UE 3e\#2 & 584475.1 & 4102826.9 & 1243.9 & 520.9 & 730.3 & $?$ & NDE & NDE \\
\hline UE 3e\#3 & 584678.5 & 4102876.1 & 1244.2 & 567.2 & $\mathrm{NDE}$ & NDE & NDE & NDE \\
\hline UE 3e\#4 & 584480.7 & 4102811.7 & 1244.2 & 543.2 & 747.7 & $?$ & NDE & NDE \\
\hline UE 3eh\#1 & 586935.2 & 4102401.6 & 1247.5 & 858.9 & $\mathrm{NDE}$ & NDE & $\mathrm{NDE}$ & $\mathrm{NDE}$ \\
\hline UE 3Lj & 584526.6 & 4101885.5 & 1239.9 & 301.1 & 715.1 & 409.3 & 359.1 & 338.3 \\
\hline UE 3mf & 584885.7 & 4101846.5 & 1239.3 & 509.3 & 809.5 & $?$ & NDE & NDE \\
\hline UE 3mo\#1 & 590049.8 & 4095704.3 & 1228.0 & 1178.4 & NDE & NDE & NDE & NDE \\
\hline UE 3mo\#2 & 590140.1 & 4096466.4 & 1230.2 & 1107.3 & $\mathrm{NDE}$ & $\mathrm{NDE}$ & $\mathrm{NDE}$ & $\mathrm{NDE}$ \\
\hline UE 4a & 584389.5 & 4106210.0 & 1266.4 & 343.5 & 915.9 & 585.8 & 375.8 & NDE \\
\hline UE 4aa & 580446.3 & 4105618.4 & 1296.6 & 924.8 & NP & NP & 951.9 & 930.6 \\
\hline UE 4ab Ins & 582167.0 & 4106418.2 & 1280.5 & 472.7 & 866.0 & 640.4 & $?$ & 505.7 \\
\hline UE 4ac & 578145.6 & 4106160.3 & 1301.8 & 790.7 & NP & NP & 868.4 & 824.8 \\
\hline UE 4ad & 581640.2 & 4104511.6 & 1274.4 & 831.5 & 953.7 & $?$ & 882.1 & 832.4 \\
\hline UE 4ae Ins & 582801.9 & 4103510.3 & 1258.8 & 509.9 & 769.9 & $?$ & 552.3 & 539.8 \\
\hline UE 4af & 579268.1 & 4103223.7 & 1312.2 & 857.7 & $\mathrm{NP}$ & NP & 1083.6 & 882.1 \\
\hline UE 4ah Ins & 582646.6 & 4104363.0 & 1262.5 & 393.5 & 595.0 & $?$ & NP & 413.6 \\
\hline UE 4ai & 581833.7 & 4105191.5 & 1273.1 & 916.5 & $?$ & $?$ & NP & 941.2 \\
\hline UE 4aL & 582212.2 & 4103965.4 & 1266.4 & 599.8 & \multicolumn{2}{|c|}{794.0} & $\mathrm{NP}$ & 757.4 \\
\hline UE 4av & 582665.1 & 4105777.0 & 1273.1 & 415.1 & 872.9 & 679.1 & 496.2 & 461.5 \\
\hline UE $4 b$ & 583435.8 & 4104286.0 & 1259.1 & 298.1 & $?$ & $?$ & 415.1 & 352.6 \\
\hline UE 4c & 583426.2 & 4105812.9 & 1268.6 & 646.8 & 826.6 & 729.1 & 705.7 & 670.0 \\
\hline UE $4 f$ & 584206.9 & 4104853.3 & 1258.5 & 163.4 & 783.0 & 342.6 & 252.1 & 187.1 \\
\hline UE $4 \mathrm{~g} \# 2$ & 584330.4 & 4106380.1 & 1265.5 & 518.2 & 793.1 & 541.3 & $\mathrm{NDE}$ & NDE \\
\hline
\end{tabular}




\begin{tabular}{|c|c|c|c|c|c|c|c|c|}
\hline \multirow{2}{*}{ Drill Hole } & \multicolumn{2}{|c|}{ Hole Coordinates } & \multirow{2}{*}{$\begin{array}{l}\text { Ground } \\
\text { Elevation } \\
\text { (m) }\end{array}$} & \multirow{2}{*}{$\begin{array}{l}\text { Total Depth } \\
\text { Elevation } \\
\text { (m) }\end{array}$} & \multicolumn{4}{|c|}{$\begin{array}{l}\text { Elevation of Top of Zone (m) } \\
\text { (See explanation at end) }\end{array}$} \\
\hline & $\begin{array}{l}\text { Easting (m) } \\
\text { UTM }\end{array}$ & $\begin{array}{c}\text { Northing (m) } \\
\text { UTM }\end{array}$ & & & ZC Zone & FS Zone & AR Zone & Pz \\
\hline UE 4p & 584546.7 & 4107086.3 & 1269.2 & 469.4 & 937.0 & 623.0 & 511.5 & 490.4 \\
\hline UE 4t & 584575.6 & 4106065.6 & 1263.1 & 527.6 & 955.2 & 616.9 & $?$ & NDE \\
\hline UE 6d & 583751.5 & 4093396.8 & 1203.0 & 15.5 & \multicolumn{4}{|c|}{ Fault } \\
\hline UE 6d\#2 & 588629.2 & 4093261.5 & 1198.5 & 745.2 & 878.4 & $?$ & NDE & NDE \\
\hline UE 6d\#3 & 588553.0 & 4093261.2 & 1198.5 & 317.9 & 857.4 & 529.4 & NP & 378.9 \\
\hline UE 6e & 587012.1 & 4093408.2 & 1199.7 & -83.2 & 675.4 & 309.7 & -3.6 & -14.9 \\
\hline UE 7aa & 589492.5 & 4102908.8 & 1298.1 & 641.6 & 1060.4 & 892.8 & 853.1 & 822.7 \\
\hline UE 7ax & 587825.8 & 4106844.6 & 1338.1 & 923.8 & 1101.9 & 984.1 & $\mathrm{NP}$ & 928.7 \\
\hline UE 7az & 587765.9 & 4104381.0 & 1285.6 & 541.6 & 957.4 & 729.4 & 631.5 & 544.4 \\
\hline UE 7ba & 584884.9 & 4104756.1 & 1258.8 & 518.8 & 981.8 & 656.8 & 566.6 & 528.5 \\
\hline UE 7bc & 588485.4 & 4103774.1 & 1287.8 & 462.7 & 1059.2 & 715.8 & 495.3 & 465.1 \\
\hline UE 7be & 586150.3 & 4106356.0 & 1292.7 & 499.0 & 965.0 & 731.8 & $?$ & 509.3 \\
\hline UE 7bh & 589420.3 & 4105240.3 & 1331.7 & 994.9 & 1200.6 & $?$ & 1017.7 & 1007.0 \\
\hline UE 7bi & 588860.2 & 4105146.6 & 1316.4 & 662.9 & 1165.6 & 917.1 & 676.3 & 664.2 \\
\hline UE 7f & 584527.1 & 4105134.5 & 1257.0 & 396.2 & 891.5 & 574.5 & 438.0 & 402.3 \\
\hline UE 7h & 588369.8 & 4106564.0 & 1338.7 & 558.1 & 1186.3 & 985.1 & 774.8 & 738.2 \\
\hline UE 7i & 586949.9 & 4106800.7 & 1319.8 & 426.7 & 1043.9 & 815.3 & 613.6 & 597.4 \\
\hline UE 7j & 587516.3 & 4106056.1 & 1315.5 & 454.2 & 1045.5 & 769.9 & 630.9 & 613.9 \\
\hline UE 7k & 586121.3 & 4104131.4 & 1257.6 & 481.0 & 965.0 & 689.2 & 533.1 & 519.4 \\
\hline UE 7L & 585228.7 & 4106657.5 & 1275.9 & 447.4 & 849.2 & 737.9 & 655.3 & 634.3 \\
\hline UE $7 \mathrm{~m}$ & 589008.5 & 4105112.1 & 1317.7 & 730.6 & 1074.4 & 941.2 & 784.0 & 766.6 \\
\hline UE $7 n S$ & 588643.6 & 4106090.5 & 1331.1 & 659.0 & 1177.1 & 913.5 & NP & 831.2 \\
\hline UE 8c & 581413.7 & 4115023.8 & 1376.2 & 922.6 & $\mathrm{NP}$ & 995.2 & NP & 974.1 \\
\hline UE 8d & 581783.2 & 4114196.5 & 1352.7 & 972.9 & NP & 1047.6 & NP & 994.6 \\
\hline UE 8e Inst & 580997.7 & 4113986.6 & 1368.2 & 615.4 & NP & 804.3 & 664.1 & 631.8 \\
\hline UE 8e\#1 & 580913.8 & 4114016.7 & 1370.4 & 576.4 & $\mathrm{NP}$ & 782.1 & 671.5 & 623.6 \\
\hline UE 8e\#2 & 580693.4 & 4113863.6 & 1374.0 & 685.2 & $?$ & $?$ & 733.9 & 703.4 \\
\hline UE 8f & 580179.9 & 4114223.2 & 1389.9 & 704.7 & $?$ & $?$ & 744.2 & 737.9 \\
\hline UE 8h & 579791.6 & 4114334.6 & 1400.3 & 909.5 & $?$ & $?$ & 1078.7 & 1025.3 \\
\hline UE 8i & 579987.9 & 4114147.3 & 1391.7 & 1026.0 & $?$ & $?$ & $\mathrm{NDE}$ & NDE \\
\hline UE 8n & 580478.1 & 4114441.8 & 1386.5 & 663.5 & 1061.9 & 1017.4 & 705.6 & 685.5 \\
\hline UE 80 & 580852.5 & 4115417.9 & 1399.0 & 1304.5 & $\mathrm{NDE}$ & $\mathrm{NDE}$ & $\mathrm{NDE}$ & NDE \\
\hline UE 9-29\#1 & 585556.1 & 4110960.8 & 1294.8 & 914.4 & $?$ & $?$ & $?$ & 947.9 \\
\hline UE 9-30.5 & 585824.2 & 4111146.1 & 1299.7 & 933.9 & \multicolumn{2}{|c|}{1043.7} & 976.0 & 958.6 \\
\hline UE 9cn & 587384.6 & 4107781.9 & 1338.4 & 893.4 & \multicolumn{2}{|c|}{1033.9} & 933.0 & 914.4 \\
\hline UE 9cp & 586012.4 & 4109113.3 & 1296.3 & 736.7 & 936.6 & 848.2 & 759.9 & 753.8 \\
\hline UE 9IS25 & 585153.2 & 4110463.3 & 1286.9 & & 878.5 & $?$ & $?$ & 689.8 \\
\hline UE 9ITS\#1 & 586695.8 & 4109741.0 & 1321.9 & 1119.8 & \multicolumn{2}{|c|}{1172.5} & NP & 1132.9 \\
\hline UE 9ITS\#2 & 586583.5 & 4111263.7 & 1319.8 & 1142.1 & $?$ & $?$ & $\mathrm{NP}$ & 1154.9 \\
\hline UE 9ITS\#3 & 585794.7 & 4110346.7 & 1296.0 & 946.4 & $?$ & $?$ & 994.2 & 985.1 \\
\hline UE 9ITS\#4 & 586040.6 & 4109738.1 & 1298.8 & 1012.2 & $\mathrm{NP}$ & $\mathrm{NP}$ & NP & 1021.7 \\
\hline UE 9ITS\#5 & 586036.1 & 4111200.8 & 1303.3 & 1036.0 & NP & NP & NP & 1047.3 \\
\hline UE U22 & 585429.9 & 4110113.8 & 1287.2 & 733.4 & $?$ & $?$ & NDE & NDE \\
\hline UE U29\#2 & 585398.1 & 4110925.8 & 1293.0 & & $?$ & $?$ & $?$ & 859.8 \\
\hline WW 2 & 581005.5 & 4113499.0 & 1362.5 & 319.5 & \multicolumn{2}{|c|}{847.4} & 609.7 & 582.0 \\
\hline
\end{tabular}

\section{Explanation}

NP = Not Present; hole penetrated stratigraphic interval, but zone is not present.

NDE = Not Deep Enough; hole bottomed above zone; zone may or may not be present.

$?=$ hole likely penetrated top of formation but existing data is insuffiecent to define zone.

Note: elevation that spans two columns indicates top of zeolitization determined but zone unknown. 
This page intentionally left blank. 


\section{Distribution List}

$\underline{\text { Copies }}$

W. R. Wilborn

5 (3 electronic)

U.S. Department of Energy

National Nuclear Security Administration

Nevada Site Office

Environmental Restoration Division

P.O. Box 98518, M/S 505

Las Vegas, NV 89193-8518

U.S. Department of Energy

1 (uncontrolled)

National Nuclear Security Administration

Nevada Site Office

Technical Library

P.O. Box 98518, M/S 505

Las Vegas, NV 89193-8518

U.S. Department of Energy

2 (electronic, uncontrolled)

National Nuclear Security Administration

Nevada Site Office

Public Reading Facility

c/o Nuclear Testing Archive

P.O. Box 98518, M/S 505

Las Vegas, NV 89193-8518

U.S. Department of Energy

1 (electronic, uncontrolled)

Office of Scientific and Technical Information

P.O. Box 62

Oak Ridge, Tennessee 37831-0062

N. M. Becker

Los Alamos National Laboratory

P. O. Box 1663, EES-6, M/S F-665

Los Alamos, NM 87545-1663

S. L. Drellack

2 (1 electronic)

Bechtel Nevada

P.O. Box 98521, NSF082

Las Vegas, NV 89193-8521

J. P. McCord

2 (1 electronic)

Stoller-Navarro Joint Venture

2 (1 electronic)

7710 W. Cheyenne, Bldg. 3, M/S 439

Las Vegas, NV 89129 


\section{Distribution List, continued}

$\underline{\text { Copies }}$

P. Montazer

1 (electronic)

Stoller-Navarro Joint Venture

7710 W. Cheyenne, Bldg. 3, M/S 439

Las Vegas, NV 89129

P. K. Ortego

2 (electronic)

Bechtel Nevada

P.O. Box 98521, NSF082

Las Vegas, NV 89193-8521

G. A. Pawloski

2 (1 electronic)

Lawrence Livermore National Laboratory

P. O. Box 808

Livermore, CA 94551-0808

S. E. Rawlinson

1 (electronic)

Bechtel Nevada

P.O. Box 98521, NTS416

Las Vegas, NV 89193-8521

C. E. Russell

2 (1 electronic)

Desert Research Institute

755 East Flamingo Road

P.O. Box 19040

Las Vegas, NV 89119-7363

G. Ruskauff

1 (electronic)

Stoller-Navarro Joint Venture

7710 W. Cheyenne, Bldg. 3, M/S 439

Las Vegas, NV 89129

Stoller Navarro Central Files

2 (1 electronic)

Stoller-Navarro Joint Venture

7710 W. Cheyenne, Bldg. 3, M/S 439

Las Vegas, NV 89129

B. K. Thompson

2 (1 electronic)

Water Resources, Nevada District

U.S. Geological Survey

160 N. Stephanie Street

Henderson, NV 89074

M. J. Townsend

2 (1 electronic)

Bechtel Nevada

P.O. Box 98521, NTS416

Las Vegas, NV 89193-8521 